JOSÉ OLIVEIRA DOS SANTOS

\title{
ESTUDO DA DEFICIÊNCIA MENTAL DE \\ HERANÇA LIGADA AO CROMOSSOMO $\mathrm{X}$
}

\author{
(Versão Corrigida)
}

Tese apresentada ao Instituto de Biociências da Universidade de São Paulo, para a obtenção de Título de Doutor em Ciências, na Área de Biologia/Genética

São Paulo 
Orientadora: Angela M. Vianna Morgante 
OLIVEIRA DOS SANTOS, JOSÉ

\section{ESTUDO DA DEFICIÊNCIA MENTAL DE HERANÇA LIGADA AO} CROMOSSOMO X

Tese (Doutorado) - Instituto de Biociências da Universidade de São Paulo, Departamento de Genética e Biologia Evolutiva

1. Deficiência Mental 2. Deficiência Mental com Herança Ligada ao X

3. Microrrearranjos Cromossômicos 4. Inativação do Cromossomo X

Universidade de São Paulo. Instituto de Biociências. Departamento de Genética e Biologia Evolutiva

\section{COMISSÃO JULGADORA}

Orientadora 
Este trabalho foi realizado com auxílio financeiro da FAPESP (Fundação de Amparo à Pesquisa do Estado de São Paulo) concedido à orientadora (FAPESP-CEPID 98/142542) e bolsa da CAPES (Coordenação de Aperfeiçoamento de Pessoal de Nível Superior) concedida ao aluno (CAPES-DS). 


\section{AGRADECIMENTOS}

Os meus sinceros agradecimentos a todos que de alguma forma contribuíram para a realização deste trabalho.

Ao Departamento de Genética e Biologia Evolutiva do Instituto e Biociências da Universidade de São Paulo, pela infraestrutura que permitiu a realização deste trabalho.

À Dra. Angela M. Vianna-Morgante, pela orientação neste projeto, por permitir que eu fizesse parte deste excelente grupo de pesquisa, pelos ensinamentos e pela confiança depositada em mim.

Ao Dr. Paulo Alberto Otto, pelos ensinamentos, pelo auxílio nas análises e por estar sempre disposto a ajudar no que fosse necessário. O exame clínico que realizou nos pacientes foi fundamental para este trabalho.

À Dra. Regina Célia Mingroni Netto, pela colaboração durante todos os anos de minha pós-graduação, mostrando-se sempre solícita.

À Dra. Carla Rosenberg por todo apoio e pelas opiniões sempre relevantes e que contribuíram muito para a realização deste trabalho.

À Dra. Débora Bertola, pela colaboração inestimável no exame clínico dos pacientes.

Aos doutorandos e amigos Adriano Bonaldi e Ana Carolina Fonseca, por estarem sempre dispostos a ajudar, fosse na realização de experimentos ou na análise e discussão de resultados, e por sermos um grupo unido e de convivência harmoniosa. 
À mestre e especialista de laboratório Silvia S. da Costa, pelos ensinamentos e apoio técnico indispensáveis à realização deste trabalho.

Aos colegas, que já passaram pelo laboratório, Larissa Fontes, Rafaela Nascimento, Sarita Badiglian e Karen Coqueti e à nova integrante do grupo Clarisse Ferreira, pela amizade e pela ajuda.

Aos técnicos do laboratório e amigos Fátima Caly, Maria Pinheiro, Ligia Vieira e Paulo Rogério de Camargo que sempre se mostraram solícitos, dispostos a fazer o que fosse possível para ajudar, e, dessa forma, contribuindo muito para que este trabalho pudesse ser realizado.

À Maraisa Sebastião, pelo apoio durante todos esses anos, ajudando-me sempre que necessitei e pela dedicação na formatação dos textos deste trabalho.

Aos colegas e amigos Lilian Kimura, Renata Watanabe, Renata Thielli, Daniela Tiaki Uehara, Teresa Auricchio, Daniel Rincon, Ana Carla, Karina Lezirovitz, Vitor Dantas, Leandro Ucela, Uirá Souto, Dayane Cruz, Renan Lemes e Juliana Prior, pela ajuda e pelos momentos de descontração.

Aos familiares dos pacientes, pela colaboração.

À minha esposa Valéria e aos meus filhos Renato e Rodrigo, pelo amor, pelo apoio, pela compreensão e pelo incentivo que sempre me deram durante esses anos. 


\section{ÍNDICE}

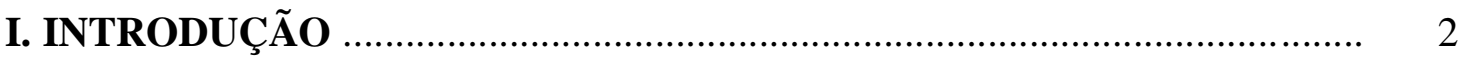

I.1. Deficiência mental.................................................................................... 2

I.2. Deficiência mental com herança ligada ao cromossomo X ........................ 3

I.3. Inativação do cromossomo X e deficiência mental...................................... 8

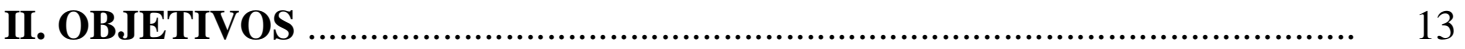

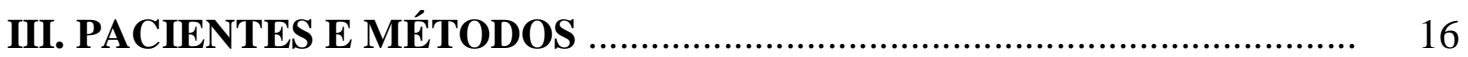

III.1. Pacientes _............................................................................. 16

III.2. Métodos ....................................................................................... 16

III.2.1. Investigação de microdeleções e microduplicações no cromossomo X - array-CGH e MLPA …............................................. 17

III.2.2. Mapeamento da deficiência mental no cromossomo X - Análise de marcadores moleculares do tipo microssatélite ............... 20

III.2.3. Análise de genes candidatos - sequenciamento direto ................ 22

III.2.4. Sequenciamento de exomas ........................................................ 22

III.2.5. Análise do padrão de inativação do cromossomo X ................... 23

IV. RESULTADOS E DISCUSSÃO _........................................................... 27

IV.1. Famílias em que a deficiência mental tem padrão de herança ligada

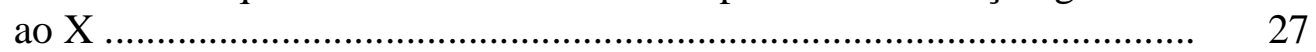

IV.1.1. FAMÍLIA 1 .................................................................. 27

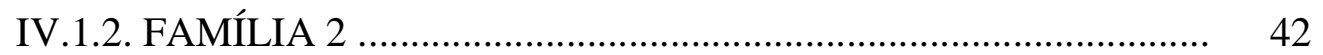

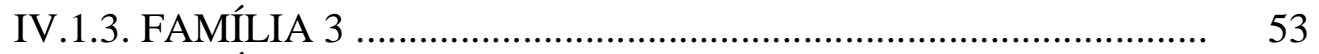

IV.1.4. FAMÍLIA 4 _.......................................................................... 64

IV.2. Irmandade com dois ou mais indivíduos do sexo masculino com deficiência mental ...................................................................................... 75

V. SUMÁRIO E CONCLUSÕES ……................................................. 81

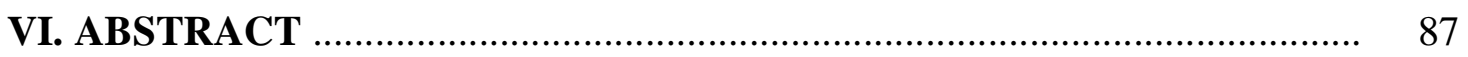

VII. REFERÊNCIAS BIBLIOGRÁFICAS _................................................. 90 


\section{INTRODUÇÃO}




\section{INTRODUÇÃO}

\section{I.1. Deficiência Mental}

A Deficiência Mental (DM) é definida como a incapacidade cognitiva caracterizada por limitações significativas nas funções intelectuais e no comportamento adaptativo, que se manifestam nas habilidades conceituais, sociais e práticas, originando-se antes dos 18 anos de idade (World Health Organization, 1992; American Psychiatric Association, 1994).

De acordo com o coeficiente de inteligência (QI) dos indivíduos afetados, a DM pode ser classificada em leve (QI entre 70 e 50), moderada (QI entre 50 e 35), grave (QI entre 35 e 20) e profunda (QI menor que 20). As formas moderada e grave têm frequência populacional de 0,3 a $0,5 \%$ e a forma leve, de 1 a $3 \%$. A DM leve corresponde a aproximadamente $80-85 \%$ dos casos de DM e está geralmente associada a níveis socioeconômicos baixos; tem etiologia predominantemente multifatorial e a desnutrição aparece como sua principal causa ambiental. Já a DM moderada - profunda tem frequência semelhante nos diferentes níveis sociais, uma indicação do componente genético predominante em sua etiologia. As estimativas da frequência da DM variam entre diferentes estudos epidemiológicos, podendo atingir até $10 \%$ em países muito pobres, devido especialmente aos altos índices de desnutrição (Chiurazzi e Oostra, 2000; Toniolo, 2000).

As formas mais graves de DM geralmente estão associadas a outras manifestações clínicas, constituindo síndromes de múltiplas anomalias congênitas e DM. As formas sindrômicas de DM são aquelas que têm o diagnóstico etiológico mais frequentemente estabelecido. Entretanto, em cerca da metade dos casos de DM 
moderada - profunda a causa permanece desconhecida. As principais causas genéticas de DM moderada - profunda são as anomalias cromossômicas e as mutações em genes únicos. Além das alterações cromossômicas detectáveis por técnicas citogenéticas convencionais, deleções e duplicações cromossômicas submicroscópicas (CNV, Copy Number Variation) foram mais recentemente identificadas como causa de cerca de 15 20\% da DM em pacientes com cariótipo normal (revisão em Devriendt e Vermeesch, 2004; Rosenberg et al., 2006).

\section{I.2. Deficiência mental com herança ligada ao cromossomo $X$}

Vários estudos em coortes de afetados por deficiência mental (DM) permitiram estimar que há 30\%-40\% mais afetados do sexo masculino (revisão em Mandel e Chelly, 2004; revisão em Ropers e Hamel, 2005). A observação de famílias em que a DM era claramente de herança ligada ao cromossomo X (DM-X) levou Lehrke (1972) a considerar mutações no cromossomo X como explicação para o excesso de homens afetados por DM em relação a mulheres, observação feita inicialmente por Penrose (1938). Essa possibilidade, sem dúvida, atraiu a atenção de vários grupos de pesquisa para a busca dos genes do cromossomo $\mathrm{X}$ relacionados à $\mathrm{DM}$.

No momento da redação deste trabalho, eram conhecidos 85 genes no cromossomo X cujas mutações são responsáveis por DM sindrômica e 39 genes mutados na DM não sindrômica, dos quais 17 foram também associados a DM sindrômica. Assim, 107 genes do cromossomo $\mathrm{X}$ já tinham sido associados a DM. (Greenwod Genetic Center - XLMR Update, Novembro 2012). Nos autossomos, cerca de 400 genes tiveram mutações identificadas como causa de DM e, portanto, aproximadamente $16 \%$ dos genes já associados a DM estão no cromossomo X, que 
contém apenas 5\% dos genes humanos; essa proporção entre genes autossômicos e do cromossomo $\mathrm{X}$ identificados como causa de DM vem-se mantendo, não diferindo daquela estimada em 2004 por Inlow e Restifo.

Em parte, esse excesso de mutações relacionadas à DM, identificadas no cromossomo X, deve decorrer da maior facilidade no mapeamento de doenças causadas por mutações no cromossomo X e também do esforço de vários laboratórios de pesquisa para identificar a causa da DM-X. Entretanto, o real enriquecimento de genes relacionados à função cerebral no cromossomo $\mathrm{X}$ é assunto abordado por vários autores (Turner e Pardington, 1991; Graves et al., 2002; Zechner et al., 2001). Essa concentração de genes com papel na função cerebral no cromossomo X ocorreria como consequência da mais rápida fixação de mutações recessivas, sob seleção positiva, no cromossomo X em comparação aos autossomos (Faster X Hypothesis; Vicoso e Charlesworth, 2006). A observação de que genes do cromossomo X têm expressão maior no cérebro de mamíferos do que genes autossômicos, em comparação com tecidos somáticos, veio apoiar a hipótese de que genes importantes para a função cerebral concentraram-se no cromossomo X durante a evolução (Nguyen e Disteche, 2006). Como sintetizam Lubs et al. (2012), o macho XY pode ter sido o animal experimental e a fêmea XX, o armazém para mutações vantajosas e deletérias.

A síndrome mais frequente entre as síndromes de DM-X é a síndrome do X frágil (SXF), que resulta de mutação no gene FMR1 (Fragil X Mental Retardation 1) e afeta um em cada 4.000-6.000 homens e uma em cada 8.000-9.000 mulheres (Crawford et al., 2001). É responsável por aproximadamente $25 \%$ dos casos familiais de DM-X (Fishburn et al., 1983) e, entre pacientes do sexo masculino com DM, a SXF tem frequência de aproximadamente 2,5\% (Biancalana et al., 2004; Strom et al., 2007). Com base nessas frequências, estima-se que cerca de $10 \%$ dos indivíduos do sexo 
masculino com DM têm uma forma de DM-X (Ropers e Hamel, 2005). Esses 10\% estão longe de explicar o excesso de cerca de $30 \%$ de homens com DM em relação às mulheres. Diferenças no desenvolvimento embrionário do homem e da mulher, tornando os homens mais susceptíveis a agressões ambientais, ou polimorfismos no cromossomo $\mathrm{X}$ associados a outros fatores são possibilidades aventadas para explicar a fração da DM no sexo masculino que não seria decorrente de mutações em genes únicos do cromossomo X (Mandel e Chelly, 2004).

Diante da reconhecida importância das mutações em genes do cromossomo $\mathrm{X}$ como causa de DM-X, concentraram-se esforços para a identificação desses genes, aplicando-se diferentes estratégias. A abordagem mais utilizada e que permitiu a identificação da maioria dos genes relacionados à DM-X $(39,1 \%)$ foi o estudo de ligação, utilizando marcadores moleculares, e a subsequente análise dos genes candidatos. Em algumas famílias pequenas, o uso de marcadores moleculares, permitindo a exclusão de segmentos do $\mathrm{X}$ não associados à doença, também tem permitido a identificação do gene mutado. Esse foi, por exemplo, o caso do estudo em nosso laboratório que levou à identificação de mutação no gene UBE2A (Ubiquitinconjugating enzime E2A) como causa de nova síndrome de DM-X (Nascimento et al., 2006). A análise dos pontos de quebra de translocações X-autossomo em mulheres afetadas por DM e de outras alterações estruturais do cromossomo $\mathrm{X}$ associadas a DM também tem sido produtiva, indicando genes alterados pelas quebras $(27,6 \%)$. Outra estratégia há muito utilizada é a busca de mutações num gene, com base no defeito metabólico $(6,7 \%)$ ou na via molecular $(5,7 \%)$, cuja associação com a doença tenha sido verificada. Outras estratégias foram introduzidas mais recentemente, como a busca de microdeleções e microduplicações cromossômicas, com a utilização de arrays genômicos $(3,8 \%)$. O sequenciamento global de regiões codificadoras de genes do 
cromossomo X em famílias com DM-X permitiu a identificação de 17,1\% dos genes mutados já identificados (Greenwod Genetic Center - XLMR Update, Novembro 2012). Ao longo dos últimos cinco anos, observa-se um aumento contínuo no número de genes relacionados a DM-X identificados, consequência dos avanços nas técnicas de sequenciamento (revisão em Lubs et al., 2012).

Quando se consideram os genes do cromossomo X já relacionados a DM, verifica-se que suas mutações não são suficientes para explicar os $10 \%$ estimados de DM-X. Excetuando o gene $F M R 1$, cuja mutação causa a síndrome do X frágil, as mutações nos genes no cromossomo $\mathrm{X}$ já associados a DM ocorrem com frequências baixas tanto nas famílias com padrão de herança ligada ao $\mathrm{X}$ como entre os casos isolados. No estudo (de Brouwer et al., 2007) de 600 famílias do banco de famílias com DM-X do EuroMRX Consortium, não incluindo a síndrome do X frágil, mutações em 90 genes do cromossomo $\mathrm{X}$ anteriormente associados a DM foram detectadas em cerca de $42 \%$, das famílias com afetados em diferentes gerações, indicando herança ligada ao $\mathrm{X}$; portanto, quando se considera que as famílias com a síndrome do $\mathrm{X}$ frágil representam $25 \%$ das famílias com DM-X, as mutações detectadas explicariam cerca da metade dos casos de DM-X. Nesse mesmo estudo, 17\% das famílias com afetados em apenas uma irmandade tiveram a DM explicada por mutações no cromossomo X e, entre os casos isolados de DM, apenas 1,4\%. Os autores estimaram que, excluindo-se o FMR1, os genes mais frequentemente alterados - ARX (Aristaless Related Homeobox), MECP2 (Methyl CpG binding protein 2), PQBP1 (Polyglutamine binding protein 1) $e$ SLC6A8 (Solute carrier Family 6 neurotransmitter transporter creatine, member 8) contribuam para $20 \%$ dos casos familiais de DM-X e para $1,4 \%$ dos casos isolados de DM no sexo masculino. 
Tarpey et al. (2009) empreenderam um grande esforço para identificar genes mutados em 208 famílias em que a deficiência mental segregava com um padrão indicativo de herança ligada ao cromossomo X, realizando o sequenciamento de exons de 718 genes do cromossomo $\mathrm{X}$, cobrindo cerca de $65 \%$ da região codificadora do cromossomo X. Esse estudo identificou nove novos genes associados a DM-X, mas a mutação causal só foi identificada em $25 \%$ das famílias. Esse número relativamente pequeno de mutações detectadas pode ter diversas explicações: a não detecção de variações no número de cópias do DNA, a localização das mutações em genes não sequenciados ou em regiões não estudadas nos genes, como íntrons, regiões reguladoras ou outras regiões não codificadoras ou ainda a inclusão de famílias que não teriam DM$\mathrm{X}$, pois havia famílias com afetados apenas em irmandades.

As dificuldades na avaliação do significado patogênico de substituições de par de bases, no estudo de sequenciamento em larga escala realizado por Tarpey et al. (2009), foram discutidas por Raymond et al. (2009). Por exemplo, grande parte das mutações nonsense não pôde ser relacionada à deficiência mental porque não segregavam com a doença na família ou estavam presentes em indivíduos da amostra controle; mostrou-se, assim, que cerca de $1 \%$ dos genes do cromossomo $\mathrm{X}$ podem aparentemente perder a função e não ter impacto clínico evidente, quando em hemizigose. No caso das mutações missense, a decisão sobre a natureza patogênica fica ainda mais difícil. Tarpey et al. (2009) usaram critérios rígidos para buscar o significado das 983 substituições diferentes que encontraram; além do estudo de segregação nas famílias, investigaram amostras controle com mais de 1000 indivíduos; levaram também em consideração a conservação evolutiva dos aminoácidos substituídos; o número de variantes do gene foi outro aspecto avaliado, pois, se maior do que a taxa de 
evolução do gene, é indicativo de seleção positiva e, numa amostra de indivíduos com deficiência mental, incluiria também aquelas variantes causadoras da doença.

Em resumo, a estimativa de aproximadamente $10 \%$ para DM-X não só deixa de explicar o excesso de homens com DM em relação a mulheres afetadas, mas também não é explicada pelas mutações nos 107 genes do cromossomo já relacionados a DM.

A contribuição de microdeleções e microduplicações (CNV), no cromossomo X para DM-X vem sendo investigada nos últimos anos, por meio de microarrays dedicados ao cromossomo X. Microdeleções e microduplicações (aparentemente patogênicas maiores do que $100 \mathrm{~kb}$ foram identificadas no cromossomo $\mathrm{X}$ em cerca de

5\% das famílias com herança ligada ao X, catalogadas no EuroMRX Consortium e a mais frequente dessas alterações foi a microduplicação que incluía o gene $M E C P 2$ (Lugtenberg et al., 2007). Essa microduplicação tinha sido antes identificada como responsável por cerca de 1\% da DM-X (Van Esch et al., 2005). Mais recentemente, Whibley et al. (2010) detectaram CNV patogênicas no cromossomo X em cerca de $10 \%$ das 251 famílias em que a DM segregava com padrão de herança sugestivo de ser ligada ao cromossomo X. Nessas famílias, nenhuma mutação de ponto fora detectada no estudo anterior do grupo, que sequenciou a região codificadora da maioria dos genes do cromossomo X (Tarpey et al., 2009). Esses estudos mostram que os microrrearranjos do cromossomo X podem explicar parte da DM-X.

\section{I.3. Inativação do cromossomo X e deficiência mental}

A inativação do cromossomo $X$ nas fêmeas de mamíferos, mecanismo de compensação da dose gênica entre machos e fêmeas, é estabelecida no início do desenvolvimento embrionário, de forma aleatória e clonal, pois, uma vez inativado, o 
cromossomo X mantém-se inativo nas células descendentes. As fêmeas são, assim, mosaicos quanto ao cromossomo $\mathrm{X}$ inativo, que pode ser o materno ou o paterno em cada uma de suas células, com igual probabilidade. Consequentemente, as fêmeas se distribuem de acordo com uma curva normal quanto à porcentagem de células com o cromossomo X materno ou paterno inativo, como demonstrado por Amos-Landgraf et al. (2006), em estudo de 415 mulheres adultas da população geral. Esses autores verificaram que apenas $1,7 \%$ das mulheres apresentavam padrões de inativação com desvios extremos (>95:5); concluíram que uma mulher qualquer da população, com tal padrão de inativação, tem probabilidades pelo menos iguais de ser portadora ou não de mutação no cromossomo $X$ que afeta a razão de inativação, justificando-se a investigação de patologias de herança ligada ao X em sua família.

As mutações no cromossomo $\mathrm{X}$ que causam deficiência mental aparecem frequentemente associadas a desvio de inativação do cromossomo $\mathrm{X}$ nas mulheres portadoras. Plenge et al. (2002) observaram que essas mutações estão preferencialmente no cromossomo $\mathrm{X}$ inativo de portadoras em 20 tipos distintos de DM-X, sugerindo que o desvio de inativação é devido à seleção contra aquelas células cujas mutações estão no cromossomo $\mathrm{X}$ ativo. Cerca de $50 \%$ das portadoras tinham desvios de inativação na proporção >80:20 e um terço delas apresentavam desvios na proporção >90:10, comparado com desvios >80:20 em apenas 9\% das 205 mulheres do grupo controle. Os autores concluíram que o desvio de inativação extremo em mães de meninos com deficiência mental é característica comum de mutações em genes do cromossomo X que causam deficiência mental, aparecendo como específico para certas mutações. Esse padrão desviado da inativação seria consequência da vantagem proliferativa das células com o alelo normal ativo. 
Em estudo realizado em nosso laboratório, Coqueti (2011) determinou o padrão de inativação do cromossomo $\mathrm{X}$ em 100 genitoras de meninos, casos isolados de deficiência mental moderada a grave, associada a outros sinais clínicos não característicos de síndrome conhecida; todos tinham cariótipos normais e teste negativo para a síndrome do cromossomo X frágil. Onze mulheres (11\%) apresentaram padrão de inativação do $X$ com desvios extremos ( $\geq 98: 2)$, frequência significativamente maior do que aquela observada por Amos-Landgraf et al. (2006) em mulheres adultas da população geral. A raridade de desvios tão extremos na população levou à conclusão de que as mães dos afetados que apresentavam tais desvios eram portadoras de mutação no cromossomo $\mathrm{X}$, que causava a deficiência mental em seus filhos. Foi, assim, estimada em $11 \%$ a frequência de deficiência mental entre meninos casos isolados de deficiência mental (IC 95\% = 0,056 - 0,188), sem incluir a síndrome do X frágil, responsável por 2,5\% a $3 \%$ da deficiência mental no sexo masculino. Essa estimativa para a proporção de DM-X entre indivíduos do sexo masculino, que constituem casos isolados de DM, é da mesma ordem de grandeza das estimativas baseadas (a) na frequência da síndrome do $\mathrm{X}$ frágil em coortes de homens com deficiência mental e entre famílias com deficiência mental de herança ligada ao $\mathrm{X}$ ou (b) nas inferências da prevalência de deficiência mental e de deficiência mental causada por mutações no cromossomo X, na população geral masculina (revisão em Ropers e Hamel, 2005). Entretanto, a frequência estimada para os casos isolados por Coqueti (2011) deve ser uma subestimativa, considerando que os desvios extremos do padrão de inativação ocorrem em apenas um terço das portadoras obrigatórias de mutações que causam DM-X (Plenge et al., 2002). Com base nos resultados desse estudo, foi indicada a avaliação do padrão de inativação do cromossomo $\mathrm{X}$ em mães de indivíduos do sexo masculino, casos isolados de 
deficiência mental, considerando a detecção de desvio extremo da inativação indicativa de DM-X.

Para investigar se os desvios extremos no padrão de inativação nas portadoras de mutação do cromossomo $\mathrm{X}$ decorrem de efeito primário no padrão de inativação ou são secundários à seleção durante o desenvolvimento, Muers et al. (2007) estudaram a expressão do gene Atrx, no desenvolvimento de camundongos. Mutações no gene humano ATRX causam DM-X e as mulheres portadoras dessas mutações apresentam desvio extremo no padrão de inativação do cromossomo X. O padrão de inativação foi determinado em fêmeas de camundongos heterozigotas quanto a mutação no gene Atrx e fêmeas sem a mutação, avaliando a presença ou não da proteína, por imunohistoquímica. Nos embriões com oito dias de idade, não houve diferença entre o número de células Atrx-negativas e positivas, o que permitiu a conclusão de que, a inativação do cromossomo X é casual no momento em que é estabelecida. A análise de diferentes tecidos durante o desenvolvimento mostrou declínio de células que não expressavam a proteína, uma indicação de que o desvio da inativação do X observado em tecidos das fêmeas adultas resulta da seleção celular, durante a formação dos tecidos. 


\section{OBJETIVOS}




\section{OBJETIVOS}

O objetivo deste trabalho foi buscar alterações no cromossomo $\mathrm{X}$ responsáveis pela deficiência mental: (A) em famílias, em que ocorriam afetados por deficiência mental, num padrão de herança ligada ao $\mathrm{X}$ e (B) em famílias com pelo menos dois afetados do sexo masculino numa irmandade, tendo sido afastadas a síndrome do cromossomo X frágil e alterações cromossômicas. No primeiro caso (A), investigamos microdeleções e microduplicações do cromossomo $\mathrm{X}$, procedemos ao mapeamento da deficiência mental, restringindo o segmento cromossômico candidato e, genes contidos nessa região cromossômica, que se expressam no cérebro, foram considerados candidatos e avaliados quanto à presença de mutações. Numa etapa posterior, alguns exomas de propósitos foram sequenciados. No segundo caso (B), com base nas indicações de que os desvios extremos de inativação do cromossomo $\mathrm{X}$ em uma mulher estão associados com alta probabilidade a mutações no cromossomo X e na observação de que esses desvios estão significativamente aumentados em mulheres certamente portadoras de mutações que causam deficiência mental de herança ligada ao $\mathrm{X}$, avaliamos a presença de desvios extremos na inativação do cromossomo $\mathrm{X}$ nas genitoras dos afetados. Foram selecionados para investigação de microduplicações e microdeleções no cromossomo $\mathrm{X}$, aqueles pacientes cujas mães apresentavam inativação do cromossomo X com desvio completo.

Encontrar novas mutações que causam DM-X pode contribuir, não somente para explicar o excesso de homens em relação a mulheres com DM na população ou os casos esperados de DM-X não explicados pelas mutações conhecidas, mas também para compreender o papel desses genes no sistema nervoso central e suas implicações no desenvolvimento da inteligência e das habilidades cognitivas e sociais. Além da 
contribuição para a pesquisa básica, a identificação desses genes tem implicações práticas no diagnóstico da fração ainda significativa de pacientes com deficiência mental de causa desconhecida e no aconselhamento genético de suas famílias. 


\section{PACIENTES E MÉTODOS}




\section{PACIENTES E MÉTODOS}

\section{III.1. Pacientes}

As famílias com afetados por deficiência mental incluídas neste estudo foram averiguadas no Serviço de Aconselhamento Genético do Laboratório de Genética Humana, Departamento de Genética e Biologia Evolutiva, do Instituto de Biociências USP, para onde foram encaminhadas para diagnóstico ou aconselhamento genético. Os afetados apresentavam deficiência mental moderada a grave, avaliada com base em suas limitações cognitivas e comportamentais. Para o estudo, foram selecionados os pacientes cujos quadros clínicos não se enquadravam em síndrome genética conhecida e que tiveram resultados normais em exame cromossômico, realizado após bandamento G, e em teste molecular para a síndrome do cromossomo X frágil.

O projeto foi aprovado pela Comissão de Ética em Pesquisa - Seres Humanos IBUSP (Protocolo 093/2009) e o consentimento esclarecido foi obtido dos responsáveis pelos pacientes.

\section{III.2. Métodos}

O DNA foi extraído de leucócitos de sangue periférico, utilizando-se o aparelho Autopure LS (Gentra Systems, Minneapolis, USA). As amostras foram quantificadas utilizando-se o NanoDrop ND-1000 (Nanodrop Technologies, Rockland, USA).

A localização de marcadores e genes nos cromossomos é dada segundo o GRCh37, hg19 (UCSC Genome Bioinformatics). 


\section{III.2.1. Investigação de microdeleções e microduplicações no cromossomo $X$ - array-CGH e $M L P A$}

A presença de desequilíbrios genômicos submicroscópicos no cromossomo $\mathrm{X}$ foi investigada pela técnica de hibridação genômica comparativa baseada em array - arrayCGH. Utilizamos a plataforma Cytosure ${ }^{\mathrm{TM}}$, Chromosome X HD microarray $2 \mathrm{x} 105 \mathrm{~K}$ (Oxford Gene Technology, OGT, UK). Esses oligoarrays contêm duas áreas com aproximadamente 105.000 oligonucleotídeos de $60 \mathrm{pb}$. Os procedimentos de purificação das amostras, hibridação e lavagem foram realizados conforme descrito pelo fabricante, com algumas modificações. Na etapa de digestão do DNA genômico, foram utilizados 800 - 1.000 ng de DNA, em volume final de $18 \mu \mathrm{L}$ de reação, contendo $5 \mathrm{U}$ de cada uma das enzimas AluI e RsaI, 1,7 $\mu \mathrm{g}$ de BSA (albumina de soro bovino) e Buffer $C$ 10X (10\% do volume final). As amostras foram digeridas por duas horas a $37^{\circ} \mathrm{C} \mathrm{em} \mathrm{estufa,}$ seguindo-se a inativação das enzimas, por $20 \mathrm{~min}$ a $65^{\circ} \mathrm{C}$. Para a marcação das amostras, foi utilizado o kit Cytosure Genomic DNA Labelling kit (OGT, Oxford, UK). Os procedimentos e quantidades de cada reagente seguiram as instruções do fabricante. Em resumo, foram adicionados random primers e tampão à reação da digestão, seguindo-se a desnaturação do DNA por 3 min a $95^{\circ} \mathrm{C}$ e a incubação em gelo por 5 min. Para a marcação, foram adicionados dNTP, Cy3-dCTP (para a amostra teste) ou Cy5dCTP (para a amostra referência) e enzima Klenow. As amostras foram mantidas por duas horas a $37^{\circ} \mathrm{C}$ em estufa, procedendo-se em seguida à inativação da enzima por

10 min a $65^{\circ} \mathrm{C}$. As amostras marcadas foram purificadas, utilizando-se Illustra ${ }^{T M}$ ProbeQuant ${ }^{T M}$ G-50 Micro Columns (GE Healthcare), de acordo com o protocolo do fabricante. A quantificação do DNA genômico marcado e a atividade específica dos fluorocromos Cy3-dCTP e Cy5-dCTP foram determinadas no espectrofotômetro NanoDrop ND-1000 (NanoDrop Technologies). Na etapa de precipitação, $50 \mu \mathrm{L}$ do 
DNA teste (marcado com Cy3) e $50 \mu \mathrm{L}$ do DNA referência (marcado com Cy5) foram adicionados a $25 \mu \mathrm{g}$ de Human Cot-1 DNA (Invitrogen), para o volume final de $125 \mu \mathrm{L}$. Em seguida, foram adicionados $\mathrm{NaAc}(3 \mathrm{M}, \mathrm{pH} 5,0 ; 10 \%$ do volume final) e etanol $100 \%$ gelado (2,5X o volume final). As amostras foram precipitadas por $15 \mathrm{~min}$ a $-80^{\circ} \mathrm{C}$ ou por duas horas a $-20^{\circ} \mathrm{C}$. Após centrifugação a $13.200 \mathrm{rpm}$, por 15 min a $4^{\circ} \mathrm{C}$, adicionou-se etanol $70 \%$ gelado às amostras e procedeu-se a centrifugação por mais 5 min a $13.200 \mathrm{rpm}$, descartando-se o sobrenadante. Seguiu-se nova centrifugação por 1 min, descartando-se o sobrenadante. O DNA marcado foi então ressuspendido em TE (Tris-HCL $10 \mathrm{mM}$, EDTA $1 \mathrm{mM}, \mathrm{pH} 8,0$ ) previamente aquecido a $72^{\circ} \mathrm{C}$ e mantido por 2 min a $72^{\circ} \mathrm{C}$, seguindo-se nova ressuspensão em vórtex. Para hibridação da amostra, foi utilizado o Agilent Oligo a-CGH Hybridization kit (Agilent Technologies, Califórnia, USA). Foram adicionadas as soluções blocking solution 10X e hybridization buffer $2 \mathrm{X}$ e procedeu-se à desnaturação por 3 min a $95^{\circ} \mathrm{C}$, seguindo-se 30 min a $37^{\circ} \mathrm{C}$. Adicionou-se todo o volume das amostras às lamelas da lâmina de suporte do microarray (GASKET slide) e colocou-se a lâmina de microarray sobre ela. As amostras foram então hibridadas a $65^{\circ} \mathrm{C}$ por aproximadamente 40 horas. A lâmina de microarray foi mergulhada em Buffer 1 por 5 min, depois em Buffer 2 (previamente aquecido a $37^{\circ} \mathrm{C}$ ) por $1 \mathrm{~min}$, seguindo $10 \mathrm{~s}$ em acetonitrila (Sigma-Aldrich, Missouri, USA) e $30 \mathrm{~s} \mathrm{em}$ Stabilization Drying Solution. As imagens do array, obtidas com o Agilent HighResolution Microarray scanner, foram processadas e analisadas, utilizando o pacote de programas Feature Extraction e Agilent Genomic Workbench (ambos da Agilent Technologies), usando o algoritmo estatístico ADM-2 e o limiar de sensibilidade 6,7. Apenas as alterações abrangendo 10 oligonucleotídeos consecutivos com razão $\log _{2}$ alterada foram consideradas pelo programa como possível alteração no número de cópias de determinado segmento genômico. 
As alterações de número de cópias identificadas nos pacientes e não associadas anteriormente a deficiência mental foram comparadas às variações documentadas no banco de dados Database of Genomic Variants (DGV), que compila as CNV presentes em amostras de indivíduos normais. Foram comparadas também às informações do Database of Chromosomal Imbalances and Phenotype in Humans using Ensembl Resources (DECIPHER), que documenta desequilíbrios genômicos identificados em indivíduos afetados por diferentes patologias.

A investigação de microduplicação do cromossomo $\mathrm{X}$, detectada em um dos probandos da Família 4, foi realizada em outros membros de sua família, por meio de MLPA (Multiplex Ligand-dependent Probe Amplification). Essa técnica permite quantificar o número de cópias de DNA das regiões de interesse. Foi utilizado o kit SALSA MLPA P106 MRX (MRC Holland, Amsterdam, NE), que contém uma mistura de 43 sondas para vários genes do cromossomo $\mathrm{X}$, que foram associados a deficiência mental e os reagentes necessários.

- Condições de hibridização e amplificação (de acordo com o fabricante): 120 ng de DNA genômico foram diluídos em $5 \mu \mathrm{L}$ de TE (Tris 10 mM - EDTA 1 mM) e desnaturados a $98^{\circ} \mathrm{C}$ por 5 min. Foram adicionados $1,5 \mu \mathrm{L}$ de MLPA Buffer e 1,5 $\mu \mathrm{L}$ de SALSA probe mix, seguindo-se desnaturação a $95^{\circ} \mathrm{C}$ por 1 min e hibridação overnight a $60^{\circ} \mathrm{C}$ (entre 16-18 h). Após a hibridação, foi adicionada uma mistura de $3 \mu \mathrm{L}$ de Ligase Buffer A, $3 \mu \mathrm{L}$ de Ligase Buffer $\mathrm{B}, 25 \mu \mathrm{L}$ de $\mathrm{H}_{2} \mathrm{O}$ e $1 \mu \mathrm{L}$ da enzima ligase (reação de ligação). Os tubos foram incubados por $15 \min$ a $54^{\circ} \mathrm{C}$ e 5 min a $98^{\circ} \mathrm{C}$. Em seguida, foi realizada a amplificação por PCR. Para o volume final de $50 \mu \mathrm{L}$, foram misturados $10 \mu \mathrm{L}$ da reação de ligação, $4 \mu \mathrm{L}$ de SALSA PCR Buffer, $2 \mu \mathrm{L}$ de iniciadores SALSA PCR, $2 \mu \mathrm{L}$ de SALSA Enzyme Dilution Buffer, 0,5 $\mu \mathrm{L}$ de SALSA polimerase e $31,5 \mu \mathrm{L}$ de $\mathrm{H}_{2} \mathrm{O}$. As condições da amplificação foram: 35 ciclos de $30 \mathrm{~s}$ a 
$95^{\circ} \mathrm{C}$, hibridação a $60^{\circ} \mathrm{C}$ por $30 \mathrm{~s}$ e extensão $72^{\circ} \mathrm{C}$ por $60 \mathrm{~s}$, seguidos de extensão final a $72^{\circ} \mathrm{C}$ por 20 min. A reação de MLPA foi realizada em amostras teste (pacientes) e controle (indivíduos fenotipicamente normais).

- Eletroforese e análise dos produtos de PCR: diluiu-se o produto da amplificação com $50 \mu \mathrm{L}$ de $\mathrm{H}_{2} \mathrm{O}$. Foram separados $2 \mu \mathrm{L}$ e adicionados $9 \mu \mathrm{L}$ de formamida HI-DI e $0,08 \mu \mathrm{L}$ do padrão de peso molecular GeneScan ${ }^{\mathrm{TM}}$ ROX 500. Os fragmentos foram separados por meio de eletroforese em capilar no aparelho ABI 3700 (Applied Biosystems). A análise foi realizada, utilizando-se o programa Coffalyser.NET (MRC Holland).

\section{III.2.2. Mapeamento da deficiência mental no cromossomo X - análise de marcadores moleculares do tipo microssatélite}

Para o mapeamento da DM nas famílias em que a doença segregava com padrão de herança ligada ao $\mathrm{X}$, foram genotipados marcadores moleculares do tipo microssatélite localizados ao longo de todo o cromossomo X. A maioria desses marcadores faz parte do kit “ABI PRISM ${ }^{\circledR}$ Linkage Mapping Set v. 2.5-MD10” (Applied Biosystems, Carlsbad, California, USA). Os demais marcadores foram selecionados em bancos de dados do NCBI - Nacional Center Biotechnology Information e Marshfield Center for Medical Genetics, levando em conta sua localização (Mb), distância genética (cM) e taxa de heterozigose.

A amplificação dos marcadores pertencentes ao kit "ABI PRISM ${ }^{\circledR}$ Linkage Mapping Set v. 2.5-MD10" foi realizada de acordo com o protocolo do fabricante. O kit possui pares de primers fluorescentes que amplificam marcadores distantes cerca de 10 cM um do outro, distribuídos por todos os cromossomos (exceto o Y). Os produtos da amplificação foram submetidos a eletroforese em capilar no Sequenciador 
MegaBACE $^{\mathrm{TM}} 1000$ (Amersham Bioscience, part of GE Healthcare, UK) e os resultados foram analisados, utilizando-se o software MegaBACE Genetic Profiler, versão 2.2 (Copyright ${ }^{\circledR}$ Amersham Bioscience, 2003). Posteriormente passamos a utilizar o analisador genético ABI 3700 (Applied Biosystems). Utilizamos $1 \mu \mathrm{L}$ da amostra diluída, $0,1 \mu \mathrm{L}$ de $\operatorname{Liz} 550$ e $9 \mu \mathrm{L}$ de formamida. Os resultados foram analisados utilizado o softwear GeneMapper versão 4.1 (Applied Biosystems).

Para os demais marcadores, a amplificação foi realizada utilizando cerca de 100 ng de DNA genômico, em volume final de reação de $25 \mu \mathrm{L}$, contendo Tris $300 \mathrm{mM}$ (pH 8,5), Hepes $100 \mathrm{mM}, \mathrm{MgCl} 25 \mathrm{mM},\left(\mathrm{NH}_{4}\right)_{2} \mathrm{SO}_{4} 100 \mathrm{mM}$, dNTP $200 \mu \mathrm{M}, 15$ pmoles de primers foward e reverse e $1 \mathrm{U}$ de Taq polimerase. O programa do termociclador consistiu em uma primeira etapa em que o primeiro ciclo tinha temperatura de $94^{\circ} \mathrm{C}$ por 1 min para desnaturação, $69^{\circ} \mathrm{C}$ por $30 \mathrm{~s}$ para hibridação dos primers e $72^{\circ} \mathrm{C}$ para extensão, seguindo-se 13 ciclos em que a temperatura de hibridação diminui $0,5^{\circ} \mathrm{C}$ por ciclo, até atingir a temperatura de $62^{\circ} \mathrm{C}$. A segunda etapa consistiu de 16 ciclos com temperatura de desnaturação de $94^{\circ} \mathrm{C}$, hibridação de $62^{\circ} \mathrm{C}$ e extensão de $72^{\circ} \mathrm{C}$, seguidos de extensão final a $72^{\circ} \mathrm{C}$ por $10 \mathrm{~min}$.

Os produtos da amplificação foram submetidos à separação eletroforética, em tampão de corrida TBE 1X (Tris-base 0,068 M; ácido bórico 0,089 M; EDTA 2 mM, pH 8,0) por, em média, 4 horas, em gel desnaturante de acrilamida (acrilamida 4,56\%, bisacrilamida 0,24\%, uréia 42\%, TEMED 0,05\% e persulfato de amônia 0,045\%). Após eletroforese, os géis foram corados por impregnação por nitrato de prata: o gel era mergulhado em solução fixadora (etanol 10\%; ácido acético 0,05\%) por 10 min e, em seguida, em solução corante ( $2 \mathrm{~g}$ de $\left.\mathrm{AgNO}_{3} / \mathrm{L}\right)$ por $10 \mathrm{~min}$, seguindo-se breve enxágue e imersão em solução reveladora ( $30 \mathrm{~g}$ de $\mathrm{NaOH}$ e $3 \mathrm{~mL}$ de formaldeído 37\%/L), até o surgimento das bandas correspondentes aos alelos do marcador. 


\section{III.2.3. Análise de genes candidatos - sequenciamento Sanger}

Os genes candidatos e suas sequências foram selecionados usando o banco de dados do NCBI (National Center for Biotechnology Information). O sequenciamento direto foi inicialmente realizado no analisador MegaBACE $^{\mathrm{TM}} 1000$ (Amersham Bioscience, part of GE Healthcare); posteriormente, passamos a utilizar o ABI 3700 (Applied Biosystems). Os exons e fronteiras exon-intron foram amplificados a partir de primers por nós desenhados, utilizando o programa PRIMER3. A especificidade dos oligonucleotídeos foi avaliada, por meio do programa BLAST (Basic Local Alignment Search Tool). Após PCR do tipo touch-down, a especificidade da amplificação da região de interesse foi confirmada por eletroforese em gel de agarose $2 \%$, em tampão TBE 1X (Tris-base 0,068 M; ácido bórico 0,089 M; EDTA 2 mM, pH 8,0), utilizando o Low DNA mass ladder (Invitrogen, Carlsbad, CA, USA), como marcador de peso molecular. Os produtos de amplificação foram purificados, usando o kit $G F X^{T M} P C R$ DNA and Gel Band purification (Amersham Bioscience, part of GE Healthcare, UK). A reação de sequenciamento foi realizada segundo protocolos dos fabricantes dos analisadores. As sequências foram analisadas no programa Sequencher 4.8.

\section{III.2.4. Sequenciamento de exomas}

O sequenciamento dos exomas foi realizado pela Oxford Gene Technology (OGT) por meio de seu serviço de sequenciamento Genefficiency ${ }^{\mathrm{TM}}$, que incorpora as plataformas Agilent SureSelect V4+UTR (captura e enriquecimento de exons), Illumina HiSeq $^{\mathrm{TM}} 2000$ (sequenciamento com cobertura de 50x) e OGT-software (análise de imagens e base-calling). São fornecidas planilhas, que incluem informações sobre read 
depth, posição genômica, alteração em relação à sequência referência, ocorrência anterior e frequência (dbSNP132), gene, transcrito e proteína, alteração de aminoácidos e predição de patogenicidade (PolyPhen, SIFT e CONDEL). Para a visualização das sequências o browser é o IGV (Integrative Genomics Viewer - Broad Institute). O software fornecido pela OGT permite filtrar as variantes, segundo critérios estabelecidos pelo usuário. Consideramos as variantes detectadas no cromossomo $\mathrm{X}$ e, nos casos em que delimitamos um segmento candidato, as variantes em genes mapeados nesses segmentos. Adotamos como critérios para a seleção das variantes em genes candidatos: (1) variantes novas: consequência grave/séria (essential splice site, frameshifting coding, stop gained, stop lost, non-synonymous coding, complex INDEL) e efeito patogênico provavelmente danoso predito por pelo menos um dos programas; foi ainda verificado se as variantes estavam presentes no dbSNP 137 e, em caso afirmativo, com frequência $<0,01$; (2) variantes conhecidas (presentes no dbSNP 132): frequência <0,01, consequência grave/séria (essential splice site, frameshifting coding, stop gained, stop lost, non-synonymous coding, complex INDEL) e efeito patogênico provavelmente danoso predito por pelo menos um dos programas. Os genes considerados candidatos foram aqueles com expressão no cérebro, tendo sido ou não anteriormente associados a deficiência mental.

\section{III.2.5. Análise do padrão de inativação do cromossomo $\mathrm{X}$}

A investigação do padrão de inativação do cromossomo X nas mães dos afetados foi realizada pela análise do padrão de metilação do gene $A R$ (Xq11-12), conforme Allen et al. (1992). O gene AR (Androgen Receptor) é membro de uma superfamília de receptores de esteróides e possui, em seu exon 1, um número variável de repetições 
CAG, traduzida em uma cadeia de poliglutaminas de comprimento variável, no domínio aminoterminal de transativação da proteína. Além de a repetição CAG ser altamente polimórfica (heterozigose de 0,9), existe, próximo a ela, um sítio de restrição da enzima HpaII, que se encontra metilado apenas no X inativo. Como a enzima HpaII é sensível a metilação, ela só é capaz de cortar os sítios que se encontram desmetilados, ou seja, aqueles localizados no cromossomo $\mathrm{X}$ ativo. Dessa maneira, pode-se determinar $\mathrm{o}$ padrão de inativação do cromossomo X. Os primers que amplificam a repetição CAG do gene $A R$ (Allen et al., 1992) flanqueiam o sítio de restrição da enzima, o que impede que os alelos digeridos pela HpaII sejam amplificados. Isso permite a determinação do padrão de inativação do cromossomo $\mathrm{X}$, a partir da análise dos alelos amplificados antes e após a digestão com a enzima HpaII.

Para cada amostra, 1.000 ng de DNA genômico foram digeridos com $10 \mathrm{U}$ da enzima HpaII (Invitrogen, Carlsbad, CA, USA), em volume final de $20 \mu \mathrm{l}$, overnight, a $37^{\circ} \mathrm{C}$ e $1.000 \mathrm{ng}$ de DNA foram incubados apenas com o tampão. Cerca de $300 \mathrm{ng}$ de DNA genômico digerido e não digerido foram amplificados por $P C R$, em volume final de reação de $30 \mu \mathrm{L}$, contendo Tris $300 \mathrm{mM}(\mathrm{pH}$ 8,5), Hepes $100 \mathrm{mM}, \mathrm{MgCl} 25 \mathrm{mM}$, $\left(\mathrm{NH}_{4}\right)_{2} \mathrm{SO}_{4} 100 \mathrm{mM}$, dNTP $200 \mu \mathrm{M}, 15$ pmoles de primers foward e reverse e $1 \mathrm{U}$ de Taq polimerase (Invitrogen). Uma amostra de DNA de homem normal foi utilizada como controle da atividade da enzima HpaII. O programa do termociclador consistiu em uma primeira etapa em que o primeiro ciclo tinha temperatura de $94^{\circ} \mathrm{C}$ por $1 \mathrm{~min}$, de $69^{\circ} \mathrm{C}$ por $30 \mathrm{~s}$ e $72^{\circ} \mathrm{C}$ para a extensão, seguido de 13 ciclos em que a temperatura de hibridação diminuía $0,5^{\circ} \mathrm{C}$ por ciclo, até atingir a temperatura de $62^{\circ} \mathrm{C}$. A segunda etapa consistiu de 16 ciclos com temperatura de desnaturação de $94^{\circ} \mathrm{C}$, hibridação de $62^{\circ} \mathrm{C}$ e extensão de $72^{\circ} \mathrm{C}$, seguidos de extensão final a $72^{\circ} \mathrm{C}$ por 20 min. Após a reação de $\mathrm{PCR}$, as amostras foram diluídas 70 vezes em água Milli-Q. A eletroforese foi realizada no 
analisador ABI 3700 (Applied Biosystems), utilizando $1 \mu \mathrm{L}$ da amostra diluída, 0,1 $\mu \mathrm{L}$ de Liz 550 e $9 \mu \mathrm{L}$ de formamida. Para análise foi utilizado o software GeneMapper. O desvio de inativação foi quantificado de acordo com a relação entre a altura do pico do menor alelo, pela soma dos picos dos dois alelos. Para correção da amplificação preferencial dos alelos menores, valores para o DNA digerido foram normalizados com os do DNA não digerido, de acordo com a fórmula: (phd1/phu1) / (phd1/phu1) + (phd2/phu2), onde phd1 é a altura do pico do menor alelo após digestão, phd2 é a altura do pico do maior alelo após digestão, phu1 é a altura do pico do menor alelo não digerido, e phu2 é a altura do pico do alelo maior não digerido (Bittel et al., 2008). 


\section{RESULTADOS E DISCUSSÃO}




\section{RESULTADOS E DISCUSSÃO}

\section{IV.1. Famílias em que a deficiência mental tem padrão de herança ligada ao $\mathbf{X}$}

\section{IV.1.1. FAMÍLIA 1}

O probando (III-1 - Figura 1) nos foi encaminhado por apresentar deficiência mental profunda associada a microcefalia, baixa estatura e fácies peculiar, tendo apresentado puberdade precoce, por volta dos nove anos de idade. Foi relatada a ocorrência de outros afetados do sexo masculino com quadro clínico semelhante, que se distribuíam na família de acordo com um padrão de herança recessiva ligada ao cromossomo X. O probando nasceu de parto normal a termo, com peso de $2.450 \mathrm{~g}$ e comprimento de $43 \mathrm{~cm}$. Era hipotônico. Sentou sem apoio com um ano de idade e andou com dois anos e oito meses. Examinado aos 12 anos apresentava retardo mental profundo, hipotonia, movimentos estereotipados e não falava. Tinha contato visual pobre, aversão ao contato físico e crises de agressão. Sua estatura era de $132 \mathrm{~cm}\left(<3^{\circ}\right.$ percentil); tinha olhos profundos, filtro nasal curto, orelhas grandes em abano e rotadas para trás, pés planos e testículos aumentados. O exame físico sempre foi prejudicado, pois o paciente não cooperava. Aos 16 anos de idade, o perímetro cefálico era de $53 \mathrm{~cm}$ $\left(2^{\circ}\right.$ percentil). O tio materno do probando, igualmente afetado, não foi examinado pela equipe médica do Serviço de Aconselhamento Genético do LGH, que pôde apenas avaliar suas fotografias. 


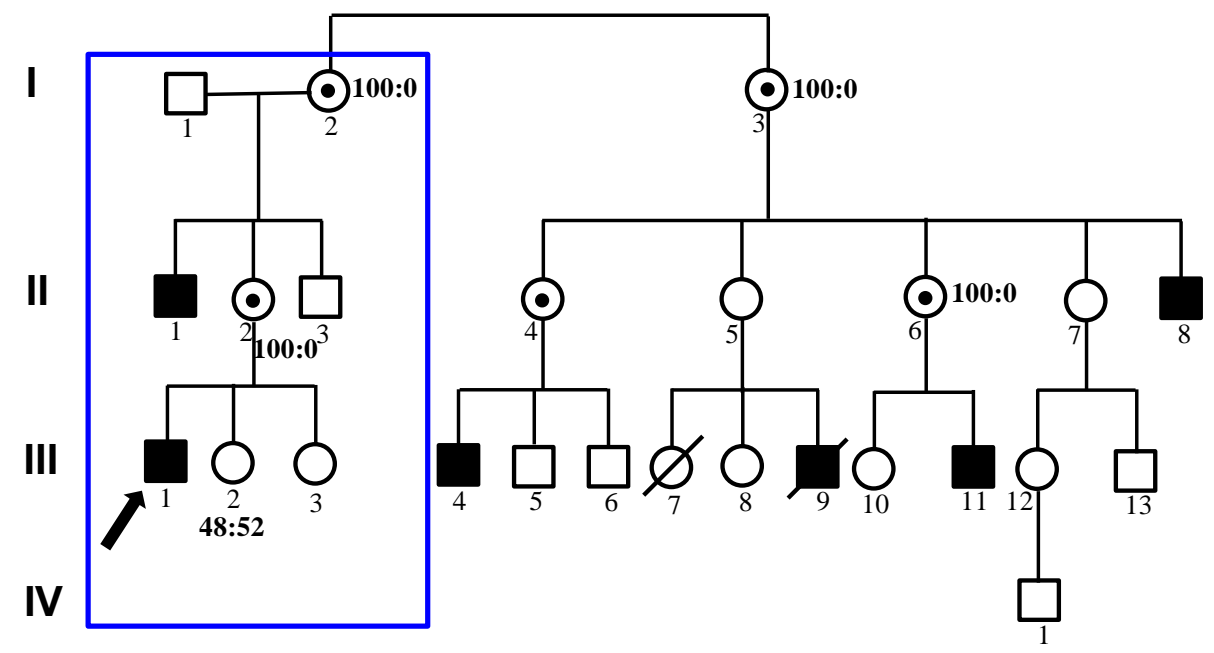

Figura 1. Família 1: Genealogia com afetados por deficiência mental, que ocorrem num padrão compatível com a herança recessiva ligada ao X. O núcleo da família originalmente estudado está delimitado pelo retângulo. O padrão de inativação do cromossomo X está indicado ao lado de cada mulher analisada.

O exame cromossômico do propósito, realizado em linfócitos de sangue periférico após bandamento $\mathrm{G}$ não revelou alterações. $\mathrm{A}$ investigação de microdesequilíbrios cromossômicos foi realizada por array-CGH, utilizando-se um array contendo 3.500 segmentos do genoma clonados em BAC e distribuídos a uma distância de $1 \mathrm{Mb}$ um do outro (Rosenberg et al., 2006). Foi detectada uma deleção em Xp11, de aproximadamente $2 \mathrm{Mb}$. Essa deleção estava presente também no tio materno do paciente (II-1 - Figura 1), com quadro clínico semelhante, mas não em seu tio clinicamente normal (II-3 - Figura 1). Foi detectada também na mãe e na avó do propósito. Portanto, a deleção apareceu como candidata para o quadro clínico de DM ligada ao X. Pouco depois, essa mesma deleção foi detectada em indivíduos clinicamente normais não pertencentes a essa família, o que nos levou a continuar o estudo da família, com o mapeamento da DM. A análise conjunta dessa família e de outras com padrão de herança ligada ao X em que ocorria essa deleção, provenientes de vários laboratórios, em comparação com amostras controle, indicou que realmente essa microdeleção não é causa de DM (Lugtenberg et al., 2010). 
Recentemente, em novembro de 2012, compareceu a nosso Serviço de Aconselhamento Genético, uma família, em que a deficiência mental tinha padrão sugestivo de herança ligada ao X. Foi realizado exame clínico dos afetados e colhido material para exames laboratoriais deles e de suas mães. Posteriormente, II-2 (Figura 1) nos contatou, informando a relação de parentesco com essa família (Figura 1: II-8 e III-11, apresentando deficiência metal e I-3 e II-6, suas mães clinicamente normais). O exame cromossômico de ambos os afetados não revelou alteração e a síndrome do cromossomo frágil foi afastada, por teste de Southern blotting em III-11.

III-11 nasceu após cerca de oito meses de gestação, por amniorrexe prematura, pesando 2.750 g. Era hipotônico. Aos seis meses de idade foi diagnosticado hipotireoidismo e estabeleceu-se terapia com Puran. Apresentou atraso do desenvolvimento neuropsicomotor, tendo andado sem apoio com dois anos e meio de idade. Mesmo após fonoterapia, nunca conseguiu falar além de poucas palavras isoladas. Aos oito anos, entrou em puberdade. Aos 12 anos e 8 meses de idade, quando compareceu a nosso Serviço de Aconselhamento Genético, não era capaz de comunicarse verbalmente nem de vestir-se ou tomar banho sem ajuda. Tinha olhos fundos. Sua estatura $(148 \mathrm{~cm})$ e perímetro cefálico $(51 \mathrm{~cm})$ estavam abaixo do $3^{\circ}$ percentil. Apresentava braquidactilia e encurtamento da falange média dos quintos dedos. A genitália era normal para a idade.

II-8 também nasceu prematuro, pesando 1.900 g. Era hipotônico e não conseguiu mamar no seio. O desenvolvimento neuropsicomotor foi atrasado e só andou sem apoio por volta dos quatro anos de idade. A fala ficou limitada a algumas palavras soltas. Passou a apresentar "desmaios" a partir de um ano e nove meses e que ocorreram até os nove anos de idade. Aos 17 anos e meio, quando foi examinado em nosso Serviço de Aconselhamento Genético, era capaz de vestir-se e tomar banho sem auxílio; não se 
comunicava verbalmente; a estatura $(142 \mathrm{~cm})$ e o perímetro cefálico $(51 \mathrm{~cm})$ estavam abaixo do $3^{\circ}$ percentil. Tinha olhos fundos. Apresentava braquidactilia e encurtamento da falange média dos quintos dedos. A genitália era normal.

\section{- Padrão de inativação do cromossomo X}

A investigação do padrão de inativação do cromossomo X, realizada na mãe do propósito (II-2 - Figura 1), em sua avó (I-2), sua tia avó materna (I-3) e em uma tia materna (II-6), portadoras obrigatórias, mostrou desvio total de inativação (100:0) em todas elas. A irmã III-2 do propósito não apresentou desvio no padrão de inativação do X (Padrão de inativação: 48:52). A outra irmã (III-3) do proposito é homozigota quanto à repetição $C A G$ do $A R$, o que não permitiu a realização do teste.

- Mapeamento da região candidata

Utilizando marcadores moleculares do tipo microssatélites, mapeamos a DM, por exclusão, num segmento de aproximadamente $29 \mathrm{Mb}$, delimitado pelos microssatélites DXS1068 (Xp11.4 - 38,908,227-38,908,332) e DXS1216 (Xq13.1 68,264,353-68,464,720) (Tabela I). No momento do mapeamento, tínhamos DNA apenas dos indivíduos I-1 e 2, II-1, 2 e 3 e III-1, 2 e 3. 
Tabela I: Marcadores moleculares do tipo microssatélite analisados na Família 1: localização no cromossomo X - Mb (GRCh37, hg 19), banda cromossômica e alelos.

\begin{tabular}{|c|c|c|c|c|c|c|c|c|c|c|c|}
\hline Marcador & $\mathbf{M b}$ & Banda & Het. & I-1 & $\mathbf{I}-2$ & II-1 & III-1 & II-2 & II-3 & III-2 & III-3 \\
\hline DXS1060 & $5,409,853-5,409,998$ & Xp22.33 & 0.84 & 2 & $1-5$ & 5 & 2 & $2-5$ & 1 & $4-5$ & $3-5$ \\
\hline DXS8051 & $9,499,372-9,499,530$ & Xp22.32 & 0.88 & 2 & $3-4$ & 4 & 2 & $2-4$ & 3 & $4-5$ & $1-4$ \\
\hline DXS987 & $14,709,303-14,709,562$ & $\mathrm{Xp} 22.31$ & 0.83 & 1 & $1-2$ & 1 & 1 & $1-1$ & 1 & $1-4$ & $1-3$ \\
\hline DXS1226 & $22,847,422-23,047,802$ & Xp22.11 & 0.84 & 4 & $2-5$ & 2 & 2 & $2-4$ & 2 & $2-3$ & $1-2$ \\
\hline DXS1214 & $31,260,993-31,261,085$ & $\mathrm{Xp} 21.2$ & 0.79 & 1 & $1-2$ & 1 & 1 & $1-1$ & 1 & $1-4$ & $1-3$ \\
\hline DXS8090 & $36,953,961-36,954,130$ & $\mathrm{Xp} 21.1$ & 0,77 & 3 & $2-3$ & 3 & 3 & $3-3$ & 2 & $1-3$ & $3-3$ \\
\hline DXS1068 & $38,908,227-38,908,332$ & Xp11.4 & 0.79 & 1 & $3-4$ & 4 & 4 & 4-1 & 3 & $2-4$ & $2-4$ \\
\hline DXS8015 & $39,784,176-39,784,361$ & Xp11.4 & 0.77 & 1 & $1 / 2$ & 1 & 1 & $1 / 1$ & 2 & $1 / 1$ & $1 / 1$ \\
\hline DXS993 & $41,147,683-41,147,988$ & $\mathrm{Xp} 11.4$ & 0.79 & 1 & $1-2$ & 2 & 2 & $2-1$ & 1 & $1-2$ & $2-2$ \\
\hline DXS8080 & $44,243,430-44,243,620$ & Xp11.3 & 0,69 & 2 & $1-2$ & 2 & 2 & 2-2 & 1 & $2-2$ & $2-2$ \\
\hline DXS1055 & $46,426,374-46,426,460$ & Xp11.23 & 0,68 & 2 & $1-2$ & 2 & 2 & $2-2$ & 1 & $2-2$ & $2-2$ \\
\hline DXS1039 & $49,458,560-49,458,698$ & Xp11.23 & 0,56 & 1 & $1-1$ & 1 & 1 & 1-1 & 1 & $1-1$ & $1-1$ \\
\hline DXS991 & $55,519,052-55,519,331$ & Xp11.21 & 0.80 & 2 & $3-1$ & 1 & 1 & $1-2$ & 3 & $1-2$ & $1-1$ \\
\hline $\mathbf{A R}$ & $66,943,551-66,944,252$ & $\mathrm{Xq} 12$ & 0,90 & 2 & $3-4^{(\mathrm{M})}$ & 4 & 4 & (M) $4-2$ & 3 & $1-2$ & (M) $4-4$ \\
\hline DXS1216 & $68,264,353-68,464,720$ & $\mathrm{Xq} 13.1$ & 0,68 & 3 & $2-3$ & 2 & 2 & $3-2$ & 2 & $2-3$ & $1-3$ \\
\hline DXS986 & $79,381,030-79,381,190$ & $\mathrm{Xq} 21.1$ & 0.77 & 2 & $2-3$ & 2 & 2 & $2-2$ & 2 & $1-2$ & $2-2$ \\
\hline DXS990 & $93,000,646-93,000,819$ & $\mathrm{Xq} 21.32$ & 0.74 & 2 & $3-3$ & 3 & 3 & $2-3$ & 3 & $2-2$ & $2-2$ \\
\hline DXS1106 & $102,732,067-102,732,245$ & $\mathrm{Xq} 22.2$ & 0.67 & 2 & $1-1$ & 1 & 1 & $1-2$ & 1 & $2-2$ & $1-2$ \\
\hline DXS1210 & $108,594,496-108,594,699$ & $\mathrm{Xq} 22.3$ & 0,80 & 2 & $2-2$ & 2 & 2 & $2-2$ & 2 & $1-2$ & $1-2$ \\
\hline DXS8055 & $114,654,942-114,655,104$ & $\mathrm{Xq} 23$ & 0.65 & 1 & $2-2$ & 2 & 2 & $1-2$ & 2 & $1-2$ & $1-2$ \\
\hline DXS8053 & $115,564,742-115,565,016$ & $\mathrm{Xq} 23$ & 0,68 & 1 & $1-2$ & 1 & 2 & $1-2$ & 2 & $1-1$ & $1-2$ \\
\hline DXS1001 & $119,836,668-119,836,873$ & $\mathrm{Xq} 24$ & 0.82 & 3 & $1-4$ & 4 & 1 & $1-3$ & 4 & $3-4$ & $1-2$ \\
\hline DXS1047 & $129,075,320-129,075,521$ & $\mathrm{Xq} 26.1$ & 0.81 & 1 & $1-1$ & 1 & 1 & $1-1$ & 1 & $1-1$ & $1-1$ \\
\hline DXS1227 & $140,802,415-140,802,588$ & $\mathrm{Xq} 27.2$ & 0.73 & 1 & $3-4$ & 3 & 4 & $1-4$ & 3 & $1-4$ & $2-4$ \\
\hline DXS8043 & $144,028,522-144,028,706$ & $\mathrm{Xq} 27.3$ & 0.80 & 2 & $2-3$ & 3 & 2 & $2-2$ & 3 & $2-3$ & $1-2$ \\
\hline DXS8091 & $147,602,856-147,602,958$ & $\mathrm{Xq} 28$ & 0.78 & 3 & $1-4$ & 1 & 4 & $3-4$ & 1 & $4-4$ & $1-4$ \\
\hline DXS1073 & $153,828,908-153,829,128$ & $\mathrm{Xq} 28$ & 0.80 & 2 & $1-2$ & 2 & 2 & $2-2$ & 2 & $1-2$ & $2-3$ \\
\hline
\end{tabular}

Azul - Marcadores segregam com a doença

Verde - Marcadores não segregam com a doença

Amarelo - Marcadores não informativos

(M) - Alelo metilado

A região delimitada para o mapeamento da DM está realçada em negrito 


\section{- Análise de genes candidatos}

A região candidata contém aproximadamente 180 genes conhecidos (http://genatlas.medecine.univ-paris5.fr/). Consideramos como os primeiros candidatos aqueles 26 já associados à DM: OTC, ATP6AP2, DMD, SYN1, SHROOM4, PHF8, NDP, BCOR, MAOA, HUWE1, PORCN, HSD17B10, FTSJ1, KDM5C, IQSEC2, FGD1, ZNF41, ZNF741, OPHN1, CASK, HDAC6, ZNF674, ZNF81, SMC1A, TSPAN7 $e$ $P Q B P 1$. Considerando que mutações diferentes em um mesmo gene podem levar a quadros clínicos diversos, incluindo DM sindrômica e não sindrômica, todos esses foram considerados candidatos.

No probando, sequenciamos 12 dos genes contidos na região candidata, ZNF81 (zinc finger protein 81), PQBP1 (polyglutamine binding protein 1), ATP6AP2 (ATPase, $H+$ transporting, lysosomal accessory protein 2), OTC (ornithine carbamoyltransferase), MAOA (monoamine oxidase A), KDM5C (lysine (K)-specific demethylase 5C), FGD1 (FYVE, RhoGEF and PH domain containing 1), HSD17B10 (hydroxysteroid (17-beta) dehydrogenase 10), SYN1 (synapsin I), SHROOM4 (shroom family member 4), TSPAN7 (tetraspanin 7) e OPHN1 (oligophrenin 1). Não foram encontradas alterações potencialmente patogênicas.

Diante do número de genes candidatos e de estar a nosso alcance o sequenciamento do exoma, decidimos não continuar o sequenciamento individual dos genes. 


\section{- Sequenciamento do exoma}

Uma amostra de DNA do propósito foi submetida ao sequenciamento do exoma pela OGT. Utilizando os critérios para seleção das variantes consideradas candidatas ao quadro clínico, conforme descrito em Métodos (III.2.4) e levando em consideração que já havíamos delimitado uma região candidata entre os marcadores DXS1068 (Xp11.4 38,908,227-38,908,332) e DXS1216 (Xq13.1 - 68,264,353-68,464,720), ficamos com dois genes candidatos, TIMP1 (TIMP tissue inhibitor of metalloproteinase 1) e HUWE1 (HECT, UBA and WWE domain containing 1, E3 ubiquitin protein ligase). As variantes encontradas nesses genes (47444746C>T, em TIMP1 e c.12378C > G, em HUWE1) foram confirmadas por sequenciamento Sanger. Estavam presentes nos afetados II-1, II-8, III-1 e III-11, em suas mães (II-1 e II-6) e avós maternas (I-2 e I-3). Não estavam presentes no tio clinicamente normal do propósito (II-3) nem em sua irmã (III-2), cujo padrão de inativação não desviado indica que não é portadora da mutação relacionada com a deficiência mental. Como esses genes estão mapeados no segmento identificado como candidato, era esperado que as variantes segregassem com a doença; entretanto, para o mapeamento do segmento candidato a conter a mutação causadora da doença, parte da família não estava disponível e, portanto, a presença das variantes nos afetados II-8 e III-11 valida sua segregação com a doença.

TIMP1 pertence à família gênica TIMP, que codifica proteínas inibidoras de metaloproteinases de matriz (MMP), um grupo de peptídeos que participa da degradação da matriz extracelular. Além de seu papel inibitório da maioria das MMP, a proteína promove a proliferação de uma grande variedade de tipos celulares e pode ter função antiapoptótica. Várias condições patológicas foram relacionadas com o excesso de MMP associado a decréscimo da proteína TIMP1: artrite reumatoide, doença de 
Crohn, ceratocone e metástases; já níveis elevados de TIMP1 foram observados em esclerose múltipla, fibrose hepática e a danos nas vias aéreas associados a asma (revisão em Anderson e Brown, 2002; Kenney et al., 2005). TIMP1 está entre os genes que se expressam no cromossomo $\mathrm{X}$ inativo; essa expressão é, entretanto, variável entre as mulheres, podendo estar ou não sujeito à inativação; essa variabilidade foi demonstrada tanto em híbridos celulares de fibroblastos humanos e roedores, contendo apenas o cromossomo $\mathrm{X}$ humano inativo, como em fibroblastos de mulheres com desvio completo da inativação do X (Anderson e Brown, 2002).

A variante $(47444746 \mathrm{C}>\mathrm{T})$, detectada no gene TIMP1, que segrega com a doença na Família 1, leva à substituição do aminoácido arginina por cisteína, em duas das seis isoformas já descritas da proteína e em outra isoforma há a substituição de prolina por leucina; nas outras três isoformas, a mutação não leva a substituição de aminoácido, sendo a alteração intrônica.

Considerando as patologias já associadas com níveis alterados de TIMP1, é pouco provável que essa mutação tenha associação causal com a deficiência mental na Família 1. O padrão de inativação do gene $T I M P 1$, com expressão no $\mathrm{X}$ inativo em algumas mulheres e em outras não, torna pouco provável o desvio completo de inativação observado em quatro mulheres da Família 1 portadoras da mutação, pois haveria aquelas em que a proteína mutante seria produzida, mesmo estando a mutação no cromossomo $\mathrm{X}$ inativo.

O gene HUWE1 codifica um membro da família de ligases de ubiquitina HECT E3. O domínio HECT (Homologous to the E6-AP Carboxyl Terminus), domínio catalítico da ligase, é altamente conservado entre espécies de vertebrados e invertebrados e se localiza na porção C-terminal da proteína; é formado por 380 aminoácidos - aminoácidos 3994 - 4374, dos quais apenas seis são cisteínas, uma delas 
no sítio catalítico, que forma ligação tioéster com ubiquitina (Scheffner et al., 1993; Huibregtse et al., 1995; Kim e Huibregtse, 2009). O gene HUWE1 participa do processo de ubiquitinação de proteínas, que consiste na adição covalente de moléculas de ubiquitina a proteínas específicas com a participação de três enzimas principais: (1) enzima ativadora de ubiquitina ou E1 (Ub-activating enzyme ), (2) enzima conjugadora de ubiquitina ou E2 (Ub-conjugating enzyme) e (3) ligase de ubiquitina ou E3 (Ubprotein ligase ). A ubiquitinação tem funções pleiotrópicas: direcionamento de proteínas para degradação via proteassoma 26S (revisão em Bochtler et al., 1999), internalização de receptores (Weissman, 2001), ativação e inativação de fatores de transcrição (Conaway et al., 2002), e modificações epigenéticas (Dover et al., 2002).

Froyen et al. (2012), estudaram a expressão do gene Huwel em camundongos por PCR quantitativo (qPCR) e constataram sua expressão em vários tecidos, incluindo córtex, hipocampo, língua, olhos, rins, fígado, glândula adrenal e fibroblastos.

O gene HUWE1 já foi associado a deficiência mental (Froyen et al., 2008; Froyen et al, 2012), como outros genes de ligases de ubiquitina [UBE3A (Ubiquitin Protein Ligase E3A), síndrome de Angelman, MIM 105830; UBR1 (Ubiquitin Protein Ligase E3 Component n-Recognin 1), síndrome de Johanson-Blizzard, MIM 243800; MID1(Midline 1), síndrome de Optiz GBBB ligada ao X, MIM 300000]. Um gene codificador de conjugase de ubiquitina também foi associado a deficiência mental UBE2A (Ubiquitin Protein Conjugase E2A) X-linked Mental Retardation Nascimento Type, MIM 300860]; a primeira mutação do gene $U B E 2 A$ causando deficiência mental foi descrita em família brasileira por Nascimento et al. (2006), que caracterizaram nova síndrome de deficiência mental de herança ligada ao X.

Num esforço colaborativo internacional liderado pelo Consórcio Europeu de Deficiência Mental (EuroMRX), o Programa Internacional GOLD (IGOLD) e 
colaborações individuais, Froyen et al. (2008) investigaram 350 famílias em que a deficiência mental sindrômica ou não sindrômica tinha padrão de herança ligada ao cromossomo $\mathrm{X}$, na busca de microdeleções ou microduplicações. Detectaram uma microduplicação em Xp11.22, ainda não descrita, como causa de deficiência mental leve a moderada em seis famílias, em cinco delas classificada como não sindrômica. As duplicações variavam de 0,4 a $0,8 \mathrm{Mb}$ e o segmento comum a todas elas incluía dois genes que foram considerados candidatos - HSD17B10 (hydroxysteroid (17-beta) dehydrogenase 10) e HUWE1 (HECT, UBA and WWE domain containing 1, E3 ubiquitin protein ligase), tendo os autores demonstrado expressão aumentada desses genes e de outros de suas vias moleculares, em células dos pacientes. HSD17B10 já tinha sido associado a doença neurológica progressiva e a deficiência mental. Froyen et al. (2012) descreveram seis outras famílias em que os afetados por deficiência mental não sindrômica apresentavam duplicações em Xp11.2, variando de 0,4 a $1 \mathrm{Mb}$; o mapeamento das doze duplicações detectadas mostrou que, no menor segmento comum a todas elas, havia apenas um gene - HUWE1.

No trabalho de 2008, Froyen et al. também investigaram mutações de ponto em HSD17B10 e em HUWE1 em 250 propósitos de famílias com deficiência mental ligada ao $\mathrm{X}$, encontrando três mutações missense diferentes em HUWE1. Em uma família australiana (A323), previamente descrita por Turner et al. (1994), foi detectada uma mutação missense, uma transição c.12037C>T no gene $H U W E 1$, resultando na substituição de uma arginina por um triptofano (R4013W), no domínio HECT. Várias mulheres portadoras tinham deficiência mental leve. Os homens afetados e as mulheres heterozigóticas apresentavam macrocefalia. Em outra família (UK444), em que os afetados tinham deficiência mental moderada e atraso na aquisição da fala, Froyen et al. (2008), identificaram uma transição c.12559C>T também no domínio HECT do gene 
HUWE1, resultando na substituição de uma arginina por uma cisteína (R4187C). Numa terceira família (UK106), foi detectada uma transição c.8942G>A no gene HUWE1, resultando na substituição de uma arginina por uma histidina (R2981H); os três afetados apresentavam deficiência mental grave a profunda, não havendo desenvolvimento da fala; um deles evitava completamente o contato visual, mesmo com seus familiares; dois dos afetados apresentavam contraturas de joelhos. Para um dos pacientes é referido déficit ponderoestatural (peso no percentil 0.4 e estatura no percentil 9) e perímetro cefálico no percentil 50.

Na Família 1 aqui estudada, os afetados, que apresentam deficiência mental profunda associada a microcefalia, baixa estatura e outros sinais, possuem uma mutação missense no exon 76 do gene $H U W E 1$, uma transversão c. $12378 \mathrm{C}>\mathrm{G}$, resultando na substituição do aminoácido cisteína por triptofano (C4126W) (Figura 2). A mutação situa-se no domínio HECT. Não só a cisteína substituída, mas a grande maioria dos aminoácidos nesse domínio é extremamente conservada entre os mamíferos (Figura 3). 
A
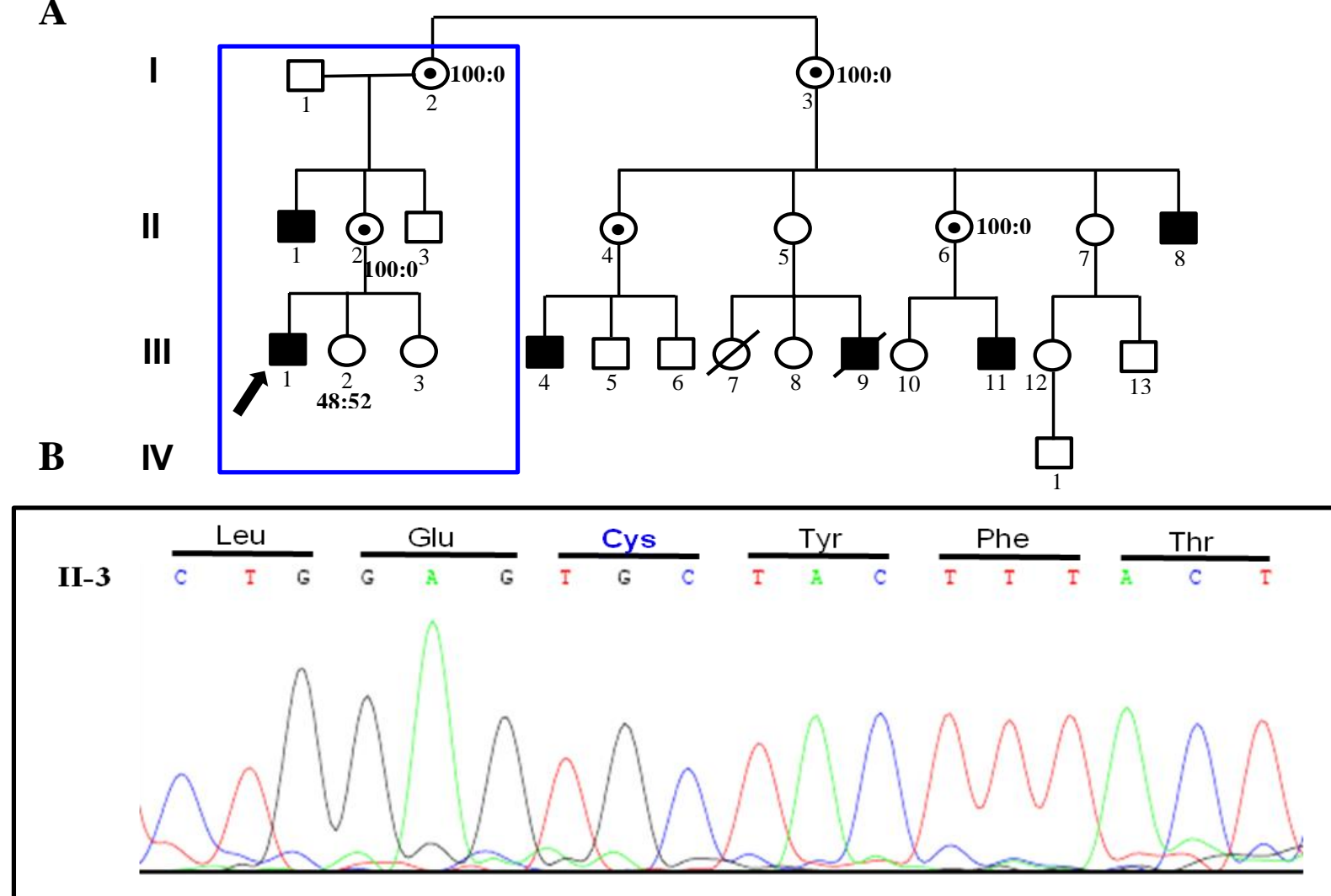

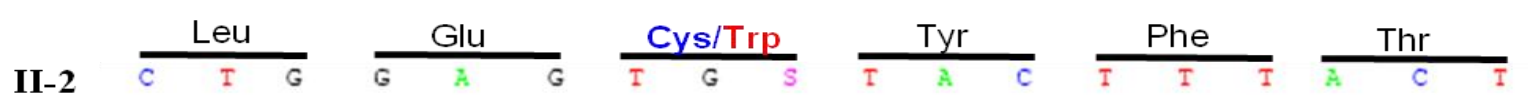
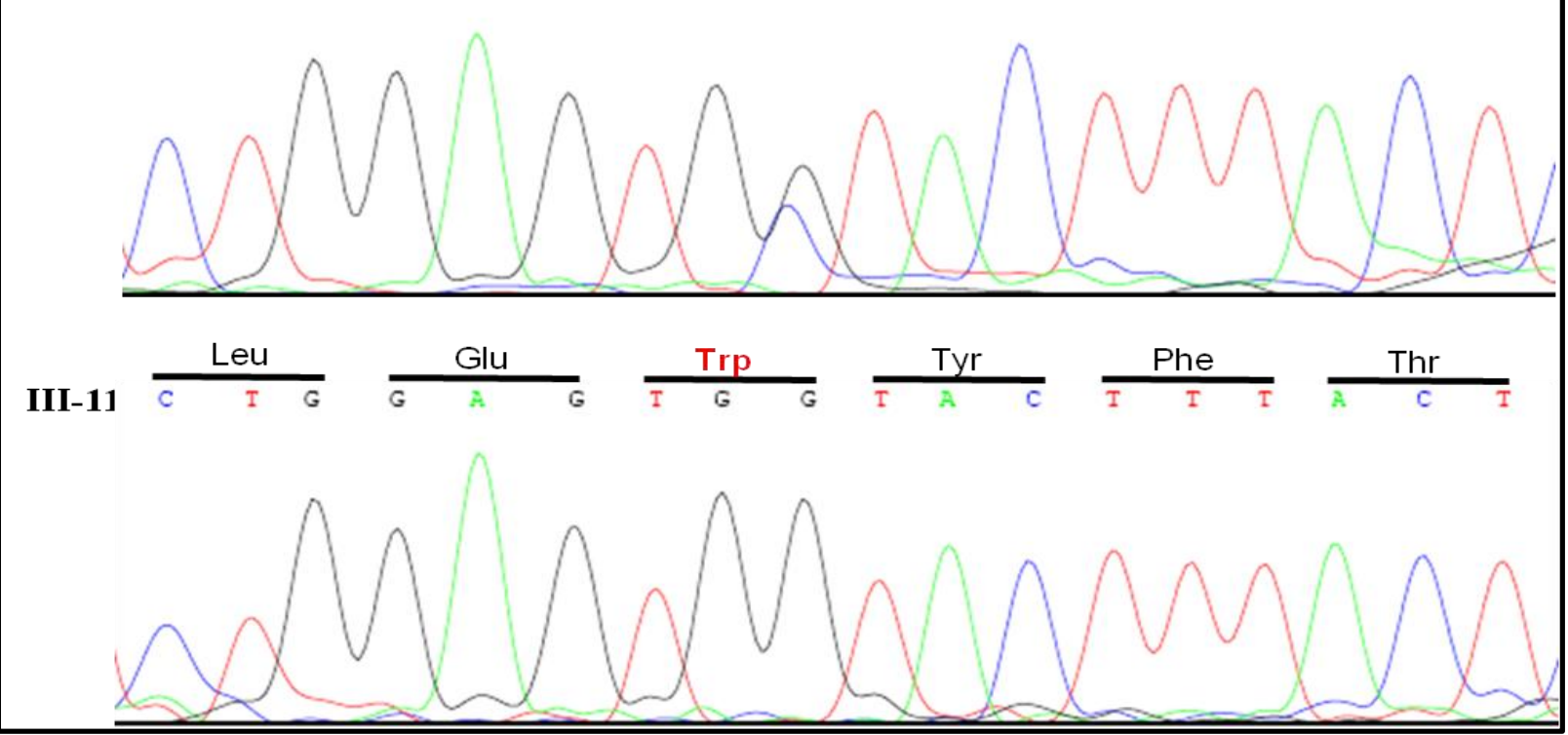

Figura 2: Mutação c.12378C>G no exon 76 do gene HUWE1. (A) Heredograma da Família 1. As mulheres em quem detectamos a mutação apresentam desvio total de inativação do cromossomo X. III-2, que não apresenta esse desvio (padrão de inativação 48:52) não é portadora da mutação. (B) Cromatogramas das fitas senso de um indivíduo normal (II-3), uma portadora da mutação (II-2) e um indivíduo afetado (III-11). 


\begin{tabular}{|lclll|}
\hline M. musculus & 4088 & SPGDRVTYTINPSSHCNPNHLSYFKFVGRIVAKAVYDNRLLECYFTRSFY & 4137 \\
B. taurus & 4085 & SPGDRVTYTINPSSHCNPNHLSYFKFVGRIVAKAVYDNRLLECYFTRSFY & 4134 \\
C. lupus & 4085 & SPGDRVTYTINPSSHCNPNHLSYFKFVGRIVAKAVYDNRLLECYFTRSFY & 4134 \\
$\boldsymbol{P}$. troglodytes & 3803 & SPGDRVTYTINPSSHCNPNHLSYFKFVGRIVAKAVYDNRLLECYFTRSFY & 3852 \\
M. mulata & 4084 & SPGDRVTYTINPSSHCNPNHLSYFKFVGRIVAKAVYDNRLLECYFTRSFY & 4133 \\
H. sapiens & 4084 & SPGDRVTYTINPSSHCNPNHLSYFKFVGRIVAKAVYDNRLLECYFTRSFY & 4133 \\
Família 1 & 4084 & SPGDRVTYTINPSSHCNPNHLSYFKFVGRIVAKAVYDNRLLEWYFTRSFY & 4133 \\
\hline
\end{tabular}

Figura 3: Alinhamento de múltiplas sequências de parte do domínio HECT da proteína HUWE1 de mamíferos, mostrando 100\% de identidade. Em azul, a cisteína substituída por triptofano, em vermelho. A cisteína substituída encontra-se na posição 4.126 na sequência polipeptídica (C4126W). A sequência de aminoácidos das proteínas HUWE1 foi obtida do HomoloGene, NCBI (http://www.ncbi.nlm.nih.gov/). 
A cisteína, aminoácido substituído pelo triptofano em nossos pacientes, é um aminoácido polar neutro que tende a formar ligações tipo dissulfeto nas cadeias polipeptídicas, desempenhando papel fundamental na conformação da estrutura terciária e consequentemente na função das proteínas. O triptofano por sua vez, é um aminoácido apolar que possui um anel aromático, apresentando composição química e estrutura muito diferente da cisteína (Figura 4). O domínio HECT do gene HUWE1 é composto por 380 aminoácidos, contendo apenas seis cisteínas, uma delas fazendo parte do sítio catalítico. Durante o processo de ubiquitinação, uma ubiquitina é transferida da cisteína catalítica da enzima conjugadora de ubiquitina (E2) para a cisteína catalítica do domínio HECT de uma ligase de ubiquitina (E3). Ao final do processo, uma molécula de ubiquitina é transferida para a proteína alvo (Scheffner et al., 1993; Huibregtse et al., 1995).

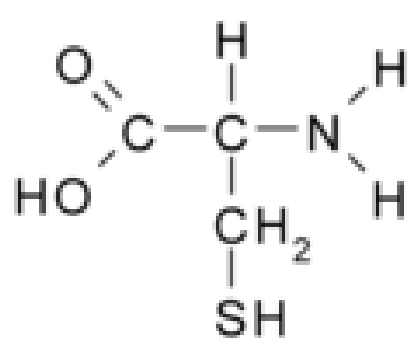

Cisteína

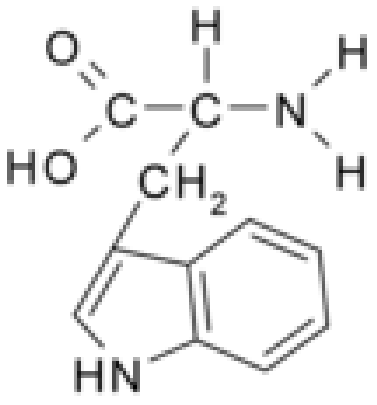

Triptofano

Figura 4: Estrutura e composição química da cisteína e do triptofano. O aminoácido cisteína possui grupamentos tiol $(\mathrm{SH})$ em sua cadeia lateral. Duas moléculas de cisteína podem interagir formando pontes dissulfeto (-S-S-). Nos afetados por deficiência mental da Família 1, detectamos uma mutação missense que substitui uma cisteína por um triptofano em um domínio evolutivamente conservado. 
Considerando que o domínio HECT é conservado evolutivamente e que outros genes que participam do processo de ubiquitinação, além de $H U W E 1$, já foram associados à deficiência mental, a mutação missense c.12378C > G, em HUWE1, levando à substituição do aminoácido cisteína por triptofano, e que segrega com a deficiência mental na Família 1, muito provavelmente é responsável pelo quadro clínico. É notável a heterogeneidade fenotípica associada a mutações e duplicações de HUWE1. No caso da Família 1, há uma deleção em $\operatorname{del}(\mathrm{X})(\mathrm{p} 11.23)$, que inclui o gene ZNF630 (Rosenberg et al., 2006), segregando com a deficiência mental. Entretanto, essa deleção não pôde ser considerada como causa de deficiência mental, ocorrendo com frequências que não diferiram estatisticamente entre indivíduos do sexo masculino, normais ou com deficiência mental (Lugtenberg et al., 2010). O gene ZNF630 é um membro do grupo primata-específico de genes zinc-finger, que inclui seis genes, dos quais ZNF41, ZNF81 e ZNF674 já tiveram mutações associadas a deficiência mental; é expresso em cérebro adulto e durante o desenvolvimento fetal (revisão em Lugtenberg, 2010). Existe, assim, a possibilidade de que essa deleção, que per se não parece causar deficiência mental, possa estar contribuindo para o quadro clínico, em associação com a mutação de HUWE1. O modelo "two-hit" para fenótipos de atraso grave do desenvolvimento neuropsicomotor foi proposto por Girirajan et al. (2010), com base na análise de uma deleção recorrente em 16p12.1; essa deleção, como único evento, mostrou-se fator que predispunha a fenótipos neuropsiquiátricos, mas exacerbava o quadro de doenças do neurodesenvolvimento, quando associadas a outras mutações já reconhecidas como causa desses fenótipos clínicos. 


\section{IV.1.2. FAMÍLIA 2}

O probando (III-1 - Figura 5) nasceu a termo, após gravidez sem intercorrências. Houve atraso no desenvolvimento neuromotor, tendo sentado sem apoio com um ano e dois meses de idade e andado com um ano e meio. As primeiras palavras foram pronunciadas também nessa idade, mas a fala continuou sempre comprometida. Examinado aos nove anos e nove meses, apresentava deficiência mental aparentemente moderada. Não conseguiu aprender a ler nem escrever. A face era triangular, com hipoplasia do maciço central. Tinha as orelhas em abano com hipoplasia moderada de cartilagem; palato alto; hiperextensibilidade articular e pés planos valgos. Seu primo materno em primeiro grau (III-5 - Figura 5) e um tio materno (II-5) apresentavam quadro clínico semelhante, porém II-5 apresentava maior comprometimento da fala e das habilidades intelectuais. Um primo em primeiro grau do propósito (II-3), filho de tio materno (II-2), foi relatado como tendo dificuldade de aprendizado. O exame cromossômico de III-1 e de III-5 não revelou alterações e a síndrome do cromossomo X frágil foi afastada por exame de Southern blotting.

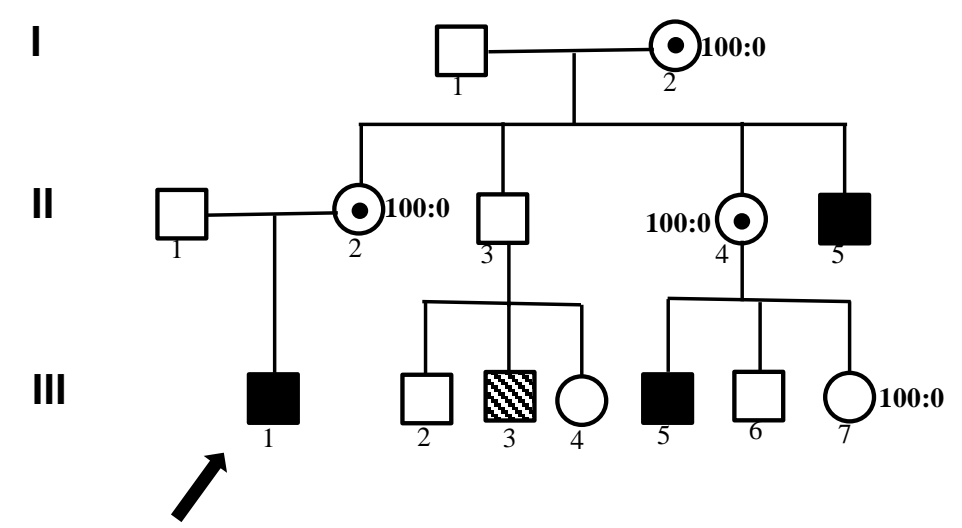

Figura 5. Família 2: Genealogia com afetados por deficiência mental, que ocorrem num padrão compatível com a herança recessiva ligada ao X. O padrão de inativação do cromossomo X está indicado ao lado de cada mulher analisada. 


\section{- Padrão de inativação do cromossomo X}

A investigação do padrão de inativação do cromossomo $\mathrm{X}$ foi realizada em quatro mulheres da família (Figura 5). A avó materna (I-2), a mãe do propósito (II-2), a tia materna (II-4), todas portadoras obrigatórias por serem mães de afetados, e a prima materna (III-7) apresentaram desvio total de inativação do cromossomo X, o que reforça a hipótese de se tratar de herança ligada ao cromossomo X.

\section{- Busca de microrrearranjos por array-CGH}

Investigamos a presença de desequilíbrios genômicos submicroscópicos no cromossomo $\mathrm{X}$ pela técnica de array-CGH, utilizando a plataforma Cytosure $^{\mathrm{TM}}$, Chromosome X HD microarray 2x105K (Oxforg Gene Technology, OGT, UK), dedicada ao cromossomo X e não encontramos alteração.

\section{- Mapeamento da região candidata no cromossomo $X$}

Os marcadores DXS1216 (Xq13.1 - 68,264,353-68,464,720), DXS986 (Xq21.1 79,381,030-79,381,190) e DXS1196 (Xq21.31 - 86,688,618-86,688,830) foram os únicos que segregaram com a deficiência mental na família (Tabela II). Muitos dos marcadores mapeados entre as bandas Xp11.4 e Xq23 não foram informativos, o que dificultou o mapeamento da região candidata nessa família. A região candidata de $70 \mathrm{Mb}$ ficou delimitada pelos marcadores DXS993 $(41,147,683-41,147,988)$ e DXS1059 (111,325,975-111,326,164). 
Tabela II: Marcadores moleculares do tipo microssatélite analisados na Família 2: localização no cromossomo X - Mb (GRCh37, hg 19), banda cromossômica e alelos.

\begin{tabular}{|c|c|c|c|c|c|c|c|c|c|c|c|}
\hline Marcador & Mb & Banda & Het. & I-2 & II-2 & II-4 & II-5 & III-1 & III-5 & III-6 & III-7 \\
\hline DXS1060 & $5,409,853-5,409,998$ & Xp22.32 & 0.84 & $1 / 3$ & $1 / 3$ & $1 / 1$ & 1 & 1 & 1 & 1 & $1 / 2$ \\
\hline DXS1223 & $8,493,939-8,494,096$ & Xp22.31 & 0,77 & $1 / 3$ & $2 / 3$ & 2/ & $?$ & 2 & 2 & $?$ & $?$ \\
\hline DXS8051 & $9,499,372-9,499,530$ & Xp22.31 & 0.88 & $1 / 2$ & $1 / 2$ & $1 / 1$ & 2 & 1 & 1 & 1 & $1 / 3$ \\
\hline DXS7108 & $10,192,237-10,192,484$ & Xp22.2 & 0.74 & $2 / 3$ & $2 / 3$ & $3 / 3$ & 2 & 3 & 3 & 3 & $1 / 3$ \\
\hline DXS987 & $14,709,303-14,709,562$ & $\mathrm{Xp} 22.2$ & 0.83 & $1 / 3$ & $1 / 2$ & $2 / ?$ & $?$ & 2 & 2 & $?$ & $?$ \\
\hline DXS1214 & $31,260,993-31,261,085$ & $\mathrm{Xp} 21.2$ & 0.79 & $1 / 2$ & $1 / 3$ & $3 / ?$ & $?$ & 1 & 3 & $?$ & $?$ \\
\hline DXS1068 & $38,908,227-38,908,332$ & Xp11.4 & 0.79 & $2 / 3$ & $1 / 3$ & $?$ & $?$ & 3 & 1 & $?$ & $?$ \\
\hline DXS993 & $41,147,683-41,147,988$ & Xp11.4 & 0.79 & $1 / 3$ & $1 / 2$ & $?$ & $?$ & 2 & 2 & $?$ & $?$ \\
\hline DXS8080 & $44,243,430-44,243,620$ & Xp11.3 & 0,69 & $\overline{1 / 1}$ & $1 / 1$ & $?$ & $?$ & 1 & 1 & $?$ & $?$ \\
\hline DXS1055 & $46,426,374-46,426,460$ & Xp11.23 & 0,68 & $1 / 1$ & $1 / 1$ & $?$ & $?$ & 1 & 1 & $?$ & $?$ \\
\hline DXS1039 & $49,458,560-49,458,698$ & Xp11.23 & 0,56 & $1 / 1$ & $1 / 1$ & $?$ & $?$ & 1 & 1 & $?$ & $?$ \\
\hline DXS991 & $55,519,052-55,519,331$ & Xp11.21 & 0.80 & $1 / 2$ & $2 / 2$ & $2 / 2$ & 2 & 2 & 2 & 2 & $2 / 2$ \\
\hline $\mathbf{A R}$ & $66,943,551-66,944,252$ & $\mathrm{Xq} 12$ & 0,90 & (M) $1 / 3$ & ${ }^{(\mathrm{M})} 1 / 3$ & $1 / 3$ & 1 & 1 & 1 & 3 & (M) $1 / 2$ \\
\hline DXS1216 & $68,264,353-68,464,720$ & $\mathrm{Xq} 13.1$ & 0,68 & $2 / 3$ & $3 / 1$ & $1 / 3$ & 3 & 3 & 3 & 1 & $1 / 3$ \\
\hline DXS986 & $79,381,030-79,381,190$ & $\mathrm{Xq} 21.1$ & 0.77 & $3 / 4$ & $1 / 4$ & $1 / 4$ & 4 & 4 & 4 & 1 & $2 / 4$ \\
\hline DXS1196 & $86,688,618-86,688,830$ & Xq21.31 & 0,79 & $2 / 3$ & $3 / 4$ & $3 / 4$ & 3 & 3 & 3 & 4 & $1 / 3$ \\
\hline DXS1217 & $88,395,845-88,396,079$ & $\mathrm{Xq} 21.31$ & 0,60 & $1 / 1$ & ? & $1 / 2$ & 1 & 1 & 1 & 2 & $1 / 2$ \\
\hline DXS990 & $93,000,646-93,000,819$ & $\mathrm{Xq} 21.32$ & 0.74 & $1 / 3$ & $1 / 1$ & $1 / 1$ & 1 & 1 & 1 & 1 & $1 / 2$ \\
\hline DXS8077 & $95,275,368-95,275,474$ & Xq21.33 & 0,72 & $2 / 2$ & $1 / 2$ & $1 / 2$ & 2 & 2 & 2 & 1 & $2 / 3$ \\
\hline DXS1106 & $102,732,067-102,732,245$ & $\mathrm{Xq} 22.2$ & 0.67 & $1 / 1$ & $1 / 1$ & ? & ? & 1 & 1 & $?$ & ? \\
\hline DXS1059 & $111,325,975-111,326,164$ & $\mathrm{Xq} 23$ & 0,71 & $2 / 3$ & $2 / 4$ & $2 / 4$ & 3 & 2 & 2 & 4 & $1 / 2$ \\
\hline DXS8055 & $114,654,942-114,655,104$ & $\mathrm{Xq} 23$ & 0.65 & $2 / 1$ & $1 / 2$ & $1 / 2$ & 2 & 1 & 1 & 2 & $1 / 3$ \\
\hline DXS8064 & $117,272,909-117,273,123$ & $\mathrm{Xq} 24$ & 0,60 & $2 / 3$ & $1 / 2$ & $?$ & ? & 2 & 1 & ? & $?$ \\
\hline DXS1001 & $119,836,668-119,836,873$ & $\mathrm{Xq} 24$ & 0.82 & $1 / 2$ & $1 / 3$ & $?$ & $?$ & 1 & 3 & $?$ & $?$ \\
\hline DXS1047 & $129,075,320-129,075,521$ & $\mathrm{Xq} 26.1$ & 0.81 & $2 / 3$ & $1 / 2$ & $?$ & $?$ & 2 & 1 & $?$ & $?$ \\
\hline DXS1062 & $137,302,993-137,303,228$ & $\mathrm{Xq} 26.3$ & 0,75 & $1 / 2$ & $1 / 1$ & $?$ & $?$ & 1 & 1 & ? & $?$ \\
\hline DXS1227 & $140,802,415-140,802,588$ & $\mathrm{Xq} 27.2$ & 0.73 & $2 / 2$ & $1 / 2$ & $?$ & $?$ & 2 & 1 & ? & $?$ \\
\hline DXS8043 & $144,028,522-144,028,706$ & $\mathrm{Xq} 27.3$ & 0.80 & $1 / 2$ & $2 / 2$ & $?$ & ? & 2 & 2 & ? & ? \\
\hline DXS8045 & $145,512,050-145,512,268$ & $\mathrm{Xq} 27.3$ & 0,54 & $1 / 2$ & $1 / 1$ & $?$ & $?$ & 1 & 1 & $?$ & $?$ \\
\hline DXS998 & $146,607,898-146,608,097$ & $\mathrm{Xq} 27.3$ & 0,58 & $1 / 1$ & $1 / 1$ & $?$ & $?$ & 1 & 1 & $?$ & $?$ \\
\hline DXS8091 & $147,602,856-147,602,958$ & $\mathrm{Xq} 28$ & 0.78 & $2 / 3$ & $1 / 3$ & $?$ & ? & 3 & 1 & $?$ & $?$ \\
\hline DXS1073 & $153,828,908-153,829,128$ & $\mathrm{Xq} 28$ & 0.80 & $1 / 2$ & $2 / 2$ & $?$ & $?$ & 2 & 2 & $?$ & $?$ \\
\hline
\end{tabular}

Azul - Marcadores segregam com a doença

Verde - Marcadores não segregam com a doença

Amarelo - Marcadores não informativos

? - Não genotipado

(M) - Alelo metilado

A região delimitada para o mapeamento da DM está realçada em negrito 


\section{- Análise de genes candidatos}

A região em que estão localizados os marcadores que segregam com a doença inclui 11 genes já associados a deficiência mental sindrômica.

A região candidata, em que estão mapeados os três marcadores que segregaram com a doença, contém os seguintes genes já associados à deficiência mental: OPHN1 (oligophrenin 1), DLG3 (discs, large homolog 3), MED12 (mediator complex subunit 12), NLGN3 (neuroligin 3), SLC16A2 (solute carrier Family 16/monocarboxylic acid transporter, member 2), ZDHHC15 (zinc finger, DHHC-type containing 15), ATRX (alpha thalassemia/mental retardation syndrome X-linked), MAGT1 (magnesium transporter 1), ATP7A (ATPase, $\mathrm{Cu}^{++}$transporting, alpha polypeptide), PGK1 (phosphoglycerate kinase 1), BRWD3 (bromodomain and WD repeat domain containing 3). Porém, uma grande região não foi informativa, como visto na Tabela II e, portanto, muitos genes além dos citados acima, podem ser considerados candidatos.

Sequenciamos os genes $P Q B P 1, H S D 17 B 10, K D M 5 C$, $S Y N 1$ e $O P H N 1$, e não encontramos alteração. Havendo a oportunidade para sequenciar o exoma, abandonamos a estratégia de analisar os genes candidatos individualmente.

\section{- Sequenciamento do exoma}

Uma amostra de DNA do propósito foi submetida ao sequenciamento do exoma pela OGT. Utilizando os critérios para seleção das variantes consideradas candidatas ao quadro clínico, conforme descrito em Métodos (III.2.4) e levando em consideração que já havíamos delimitado uma região candidata entre os marcadores DXS993 $(41,147,683-41,147,988)$ e DXS1059 (111,325,975-111,326,164 foi), ficamos com dois genes candidatos, TAF1 (TAF1 RNA polymerase II, tata box-binding protein-associated factor) e SHROOM4 (shroom family member 4), descrito inicialmente como KIAA1202. 
As variantes encontradas nesses genes (c.4406A>T, em TAF1, substituindo uma histidina por leucina (H1469L) e c.1413C>A em SHROOM4, substituindo uma prolina por treonina $(\mathrm{P} 463 \mathrm{~T})$ ) foram confirmadas por sequenciamento direto. Estavam presentes nos afetados (II-5, III-1 e III-5), em suas mães (II-2 e II-4) e avó materna (I-2) e também em III-7, que é irmã de afetado (III-5) e que apresenta desvio completo de inativação do X (Figura 5). As variantes não estavam presentes em III-6, irmão clinicamente normal de afetado. Como esses genes estão mapeados no segmento identificado como candidato, era esperado que as variantes segregassem com a doença.

TAF1, ou TAFII250, é a subunidade maior do fator de transcrição TFIID, um complexo proteico de ligação com o DNA, necessário para a transcrição, mediada pela RNA polimerase II, de muitos genes codificadores de proteínas, na célula eucariótica (revisão em Wassarman e Sauer, 2001).

A mutação missense, uma transversão c.4406A>T detectada na Família 2, substitui o aminoácido histidina por leucina (H1469L). Analisando a sequência polipeptídica, incluindo 100 aminoácidos em torno da histidina substituída, verificamos que é extremamente conservada entre os mamíferos, apresentando $100 \%$ de identidade entre Mus musculus, Rattus norvegicus, Macaca mulatta, Bos taurus, Canis lupus e Homo sapiens (Figura 6). A única doença já associada ao gene TAF1 foi a distonia de torsão-parkinsonismo (MIM 314250), de manifestação tardia, com o aparecimento dos primeiros sinais na terceira década de vida. Makino et al. (2007) relacionaram o gene TAF1 com a doença, em pacientes da ilha Panay, nas Filipinas, onde é particularmente frequente $(5: 100,000)$, descrevendo uma inserção de um retrotransposon no intron 32 , associada com decréscimo nos níveis de TAF na análise de cérebros post-mortem. Os autores concluíram que a diminuição na expressão de uma ou mais isoformas de TAF1, específicas de neurônios, era responsável pela doença. 


\begin{tabular}{|lllll|}
\hline M. musculus & 1430 & DLPNTYPFHTPVNAKVVKDYYKIITRPMDLQTLRENVRKRLYPSREEFRE & 1479 \\
R. morvegicus & 1419 & DLPNTYPFHTPVNAKVVKDYYKIITRPMDLQTLRENVRKRLYPSREEFRE & 1468 \\
M. mulatta & 1331 & DLPNTYPFHTPVNAKVVKDYYKIITRPMDLQTLRENVRKRLYPSREEFRE & 1380 \\
B. taurus & 1556 & DLPNTYPFHTPVNAKVVKDYYKIITRPMDLQTLRENVRKRLYPSREEFRE & 1605 \\
C. lupus & 1419 & DLPNTYPFHTPVNAKVVKDYYKIITRPMDLQTLRENVRKRLYPSREEFRE & 1468 \\
H. sapiens & 1419 & DLPNTYPFHTPVNAKVVKDYYKIITRPMDLQTLRENVRKRLYPSREEFRE & 1468 \\
\hline
\end{tabular}

\begin{tabular}{|lllll|}
\hline M. musculus & 1480 & HLELIVKNSATYNGPKHSLTQISQSMLDLCDEKLKEKEDKLARLEKAINP & 1529 \\
R. norvegicus & 1469 & HLELIVKNSATYNGPKHSLTQISQSMLDLCDEKLKEKEDKLARLEKAINP & 1518 \\
M. mulatta & 1381 & HLELIVKNSATYNGPKHSLTQISQSMLDLCDEKLKEKEDKLARLEKAINP & 1430 \\
B. taurus & 1606 & HLELIVKNSATYNGPKHSLTQISQSMLDLCDEKLKEKEDKLARLEKAINP & 1655 \\
C. lupus & 1469 & HLELIVKNSATYNGPKHSLTQISQSMLDLCDEKLKEKEDKLARLEKAINP & 1518 \\
H. sapiens & 1469 & HLELIVKNSATYNGPKHSLTQISQSMLDLCDEKLKEKEDKLARLEKAINP & 1518 \\
Família 2 & 1469 & LLELIVKNSATYNGPKHSLTQISQSMLDLCDEKLKEKEDKLARLEKAINP & 1518 \\
\hline
\end{tabular}

Figura 6: Alinhamento das sequências de 100 aminoácidos da proteína TAF1 de mamíferos ao redor da histidina substituída pela mutação, c.4406A>T, mostrando $100 \%$ de identidade. Em azul, a histidina substituída por leucina (em vermelho). A histidina substituída encontra-se na posição 1,469 na sequência polipeptídica (H1469L). A sequência de aminoácidos das proteínas TAF1 foi obtida do HomoloGene, NCBI (http://www.ncbi.nlm.nih.gov/). 
O gene SHROOM4 codifica um membro da família APX/SHROOM; em humanos, a família de proteínas SHROOM inclui três membros, SHRM2, SHRM3 e SHRM4, o mesmo ocorrendo em camundongos; já Shrm1 foi encontrada apenas em Xenopus; a proteína SHROOM4 contém um domímio PDZ N-terminal e um motivo ASD2 (APX/SHRN Domain 2) C-terminal; os outros membros da família possuem também um domínio ASD1 central (revisão em Yoder e Hildebrand, 2007). Estudo em camundongos indica que shroom4 é uma proteína que se liga a actina, regulando a arquitetura celular, provavelmente ao mediar a localização da miosina II; durante o desenvolvimento é expressa em vários tecidos, incluindo o cérebro, e deve ter papel importante no desenvolvimento dos vertebrados (Yoder e Hildebrand, 2007). A expressão da proteína humana fora antes observada em vários tecidos adultos e fetais, incluindo o cérebro, e sua colocalização com o citoesqueleto de F-actina fora demonstrada (Hagens et al, 2006).

Na Família 2 (Figura 5), a mutação missense c.1413C>A no exon 4 do gene SHROOM4, resulta na substituição do aminoácido prolina por treonina (P463T). A prolina substituída é altamente conservada entre os mamíferos (Figura 7). As três mulheres portadoras obrigatórias (I-2, II-2 e II-4) e a prima do propósito (III-7), que apresentam desvio total de inativação do cromossomo $\mathrm{X}$ são heterozigóticas quanto à mutação c.1413C>A, que não está presente em irmão clinicamente normal de afetado (III-6 - Figura 7). 


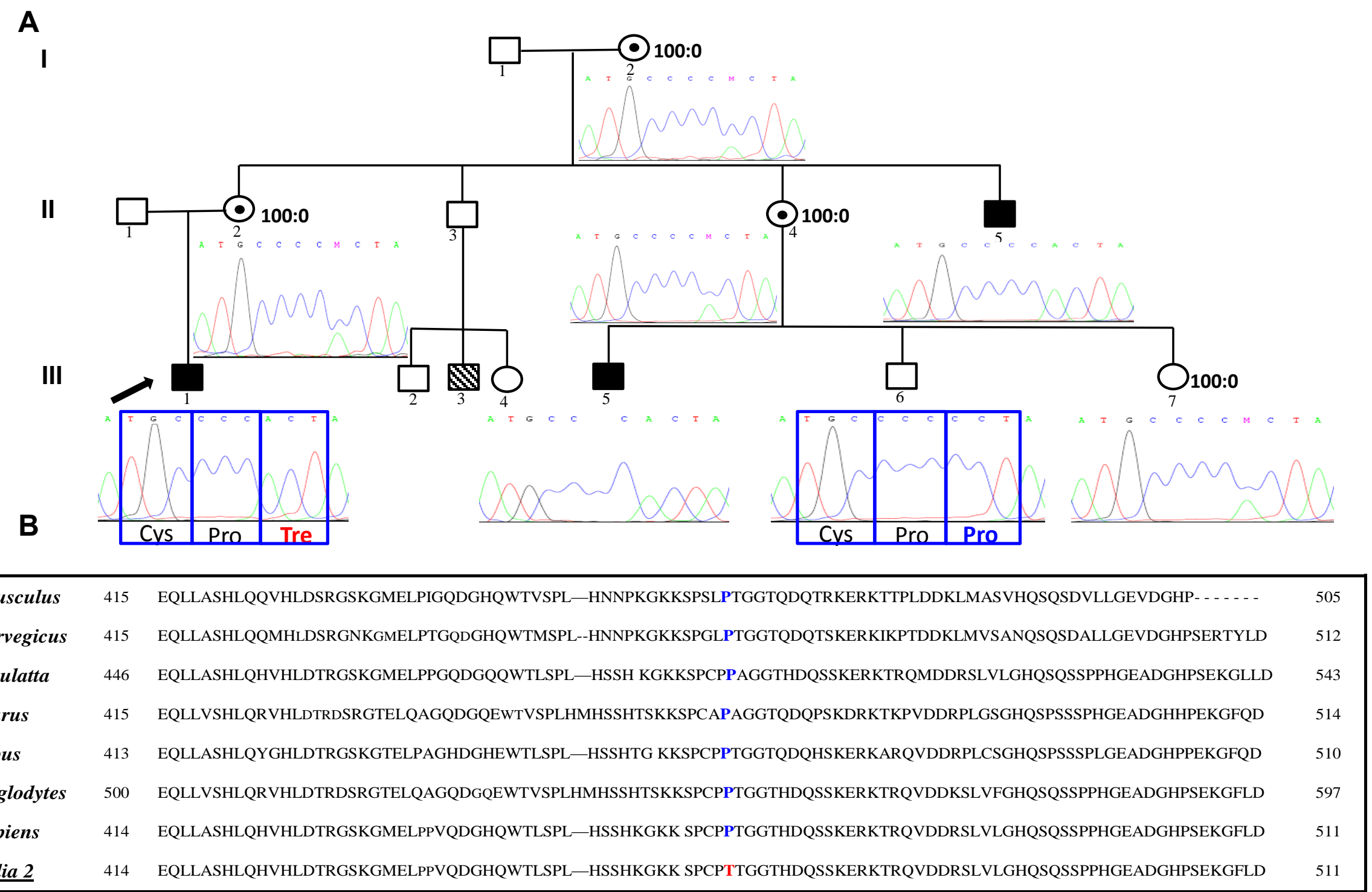


A prolina é um aminoácido com cadeia lateral apolar enquanto que a treonina faz parte de um grupo de aminoácidos com cadeia lateral polar eletricamente neutra, as duas diferindo em sua composição química e estrutura (Figura 8). A diferença na estrutura e composição de aminoácidos pode alterar a estrutura tridimensional da proteína, prejudicando sua função.

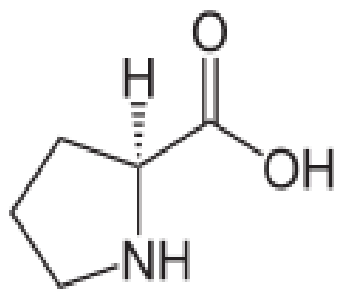

Prolina

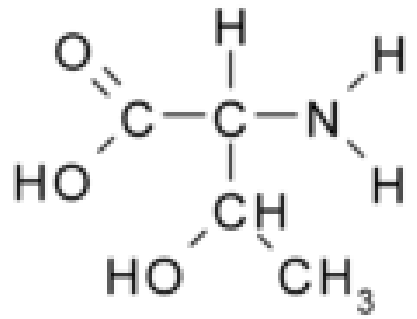

Treonina

Figura 8: Estrutura e composição química da prolina e da treonina. Nos afetados por deficiência mental da Família 2, encontramos uma mutação missense que substitui uma prolina por treonina, segregando com a doença na família.

O gene SHROOM4 já foi associado a deficiência mental. Stocco dos Santos et al. (1991) descreveram uma família brasileira na qual quatro homens relacionados por suas mães apresentavam deficiência mental grave, hiperatividade, atraso na aquisição ou ausência de fala, convulsões e infecções respiratórias recorrentes; tinham baixa estatura, hirsutismo, cifose, luxação congênita do quadril bilateral, epicanto e estrabismo. Stocco dos Santos et al. (2003) delimitaram a região candidata nessa família entre Xp11.3 Xq21.3, incluindo os marcadores DXS1003 e DXS8077. Hagens et al. (2006) encontraram, nessa família, uma mutação missense c.3266C>T no gene SHROOM4, resultando na substituição do aminoácido serina por leucina (S1089L). Como as mães dos afetados, portadoras da mutação, apresentavam convulsões e períodos de depressão, os autores sugeriram que é provável que alguma proteína mutante estivesse presente nas células dessas portadoras, com efeito dominante negativo, sendo responsável pelo 
fenótipo clínico moderado apresentado por essas mulheres. Os estudos de inativação do cromossomo $\mathrm{X}$ realizados em células de sangue periférico, em todas as portadoras obrigatórias, mostrou desvios por volta de 90:10. As mulheres portadoras na Família 2 aqui estudada são clinicamente normais e a inativação do $\mathrm{X}$ é completa em células do sangue periférico.

Hagens et al. (2006) também investigaram pontos de quebra em duas translocações equilibradas $\quad \mathrm{X}$;autossomo $\quad-\quad 46, \mathrm{X}, \mathrm{t}(\mathrm{X} ; 8)(\mathrm{p} 11.2 ; \mathrm{p} 22.3) \quad \mathrm{e}$ 46,X,t(X;19)(p11.2;p13.3), em duas mulheres não aparentadas, que apresentavam deficiência mental. O ponto de quebra em Xp11.2 rompia o gene SHROOM4. Enquanto a portadora da $\mathrm{t}(\mathrm{X} ; 8)$ apresentava deficiência mental leve-moderada e dismorfismos faciais discretos, a portadora da $\mathrm{t}(\mathrm{X} ; 19)$ tinha maior comprometimento mental, contato social pobre, fala altamente comprometida, com vocabulário limitado, tendo falecido após transplante cardíaco devido a displasia ventricular. Para explicar as diferenças entre os quadros clínicos das portadoras dessas translocações, os autores consideraram a possibilidade de efeito adicional dos genes nos pontos de quebra dos autossomos 8 e 19 . A inativação do cromossomo $\mathrm{X}$ mostrou desvios em ambas as mulheres, com padrão 95:5 na portadora da translocação $t(X ; 8)$ e $89: 11$, na portadora da translocação $t(X ; 19)$; a análise citológica mostrou que o cromossomo $\mathrm{X}$ estruturalmente normal era $\mathrm{o}$ predominantemente inativo, como ocorre em portadoras de translocações cromossômicas equilibradas entre $\mathrm{X}$ e autossomo. O fenótipo dessas mulheres deveria, portanto, assemelhar-se aos dos homens afetados portadores de mutação missense na família descrita originalmente por Stocco-Santos et al. (1991); entretanto os fenótipos diferem, como salientam Hagens et al. (2006). As diferenças de quadro clínico poderiam ser decorrentes, da ausência total da proteína, devido à ruptura do gene no caso das translocações e à presença de proteína alterada no caso dos homens afetados. 
Uma deleção de SHROOM4 em um menino descrito como apresentando apenas deficiência mental moderada foi descrita posteriormente por Honda et al. (2010). A variabilidade das manifestações clínicas associadas a mutações do gene SHROOM4 pode, portanto, ser explicada pelo tipo de mutação, tendo, entretanto, que ser levados em conta outros fatores genéticos e também os ambientais. Para a deficiência mental de herança ligada ao X, é ilustrativa, por exemplo, a variabilidade clínica associada a uma mesma mutação no gene PQBP1 (polyglutamine-binding protein 1) (Kalscheur et al., 2003). Também observamos variações fenotípicas entre os portadores da mutação que descrevemos na Família 2, o indivíduo II-5 (Figura 7A) apresentando quadro clínico mais grave que os outros afetados da família.

Na Família 2, a mutação missense que relatamos no gene SHROOM4 aparece como a causa mais provável da deficiência mental, em comparação com a mutação do outro candidato posicional $T A F 1$, particularmente considerando os fenótipos clínicos já associados a esses genes. As manifestações clínicas dos afetados não permitem, entretanto, caracterização clínica de uma síndrome, como acontece também com as mutações de SHROOM4 anteriormente descritas. 


\section{IV.1.3. FAMÍLIA 3}

A família inclui dois irmãos e um primo materno em primeiro grau com deficiência mental (Figura 9).

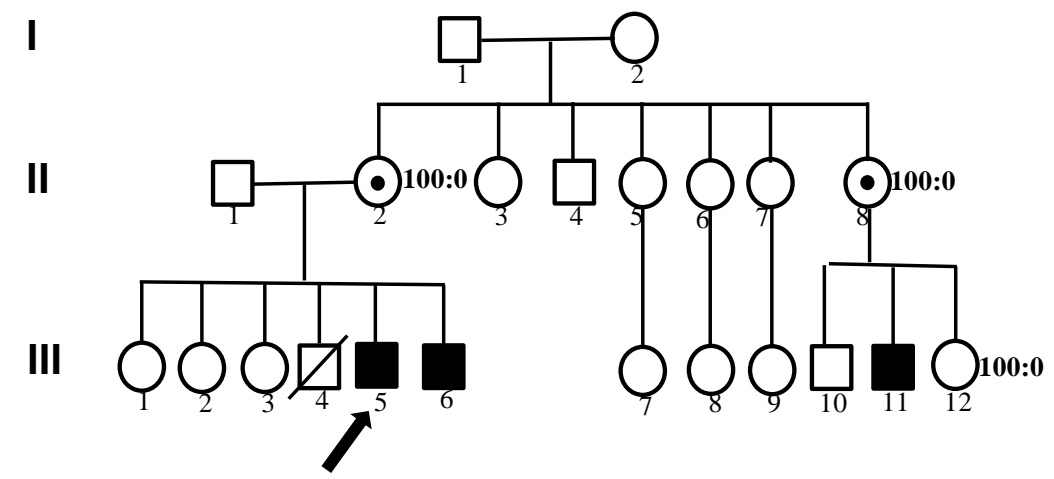

Figura 9. Família 3: Genealogia com afetados por deficiência mental, que ocorrem num padrão compatível com a herança recessiva ligada ao X. O padrão de inativação do cromossomo X está indicado ao lado de cada mulher analisada.

O probando (III-5 - Figura 9) nasceu de parto normal, após 28 semanas de gestação. A família não soube informar peso, comprimento e perímetro cefálico ao nascimento. Apresentou atraso no desenvolvimento neuropsicomotor, tendo andado aos dois anos e cinco meses de idade. Examinado no Serviço de Aconselhamento Genético do Departamento de Genética e Biologia Evolutiva, IB-USP aos cinco anos de idade, sua estatura era de $109 \mathrm{~cm}$ (percentil 50) e o perímetro cefálico, de 53,5 cm (percentil 98). Apresentava dolicocefalia, face triangular, frontal abaulado, hipoplasia da porção média da face, hipertelorismo ocular (DII 3,7 cm, >97 percentil; DIE 8,4 cm, entre os percentis 75 e 97), epicanto, cílios longos, ponte nasal baixa, nariz bulboso, filtro longo, lábio superior em arco de cupido, palato alto, orelhas pequenas levemente hipoplásicas com hélices superiores hiperenroladas; braquidactilia; criptorquidia bilateral. Não falava e era hiperativo. O exame ecocardiográfico, realizado aos 9 anos de idade, não revelou alteração. 
O irmão do probando (III-6 - Figura 9) nasceu de parto normal após 24 semanas de gestação, pesando 960 g. Apresentou retardo do desenvolvimento neuropsicomotor, tendo andado aos dois anos e meio de idade. Examinado em nosso Serviço de Aconselhamento Genético à idade de três anos e nove meses, sua estatura era de $97 \mathrm{~cm}$ $\left(<3^{\circ}\right.$ percentil $)$ e perímetro cefálico de $55 \mathrm{~cm}\left(>98^{\circ}\right.$ percentil). Apresentava dolicocefalia, face triangular, frontal abaulado, hipoplasia da porção média da face, hipertelorismo ocular (DII 3,3 cm, percentil 97; DIE 7,9 cm, percentil 75), epicanto, ponte nasal baixa, nariz bulboso, filtro longo, lábio superior em arco de cupido, orelhas pequenas levemente hipoplásicas com hélices superiores hiperenroladas; braquidactilia; criptorquidia bilateral. Não falava e era hiperativo. O exame ecocardiográfico realizado aos dois meses de idade revelou foramen oval pérvio, sem repercussão hemodinâmica. Aos oito meses e meio de idade, a ultrassonografia de abdômen total mostrou hidronefrose acentuada e dilatação ureteral à esquerda. Aos três anos e meio, no exame de uretrocistografia miccional com contraste, foi detectado refluxo vésico-uretral grau 4/5 à direita. Submeteu-se a estudo renal com ou sem diuréticos (ESTRDD), após administração endovenosa de DTPA $^{-99 \mathrm{~m}} \mathrm{Tc}$, tendo sido verificado que a função glomerular estava conservada globalmente, porém foi observada estase funcional dos rins, mais evidente à direita. O exame cromossômico do propósito e de seu irmão não revelou alteração e a síndrome do X frágil foi afastada por teste de Southern blotting.

A irmandade inclui ainda três meninas clinicamente normais e um menino falecido aos seis meses de idade (III-4 - Figura 9), que foi relatado como apresentando tetralogia de Fallot.

O primo do propósito (III-11 - Figura 9) nasceu a termo, após cesariana, a família não sabendo informar seu peso ou comprimento. No oitavo mês de gestação, o ultrassom morfológico revelara "defeito cardíaco" e a mãe informou que houve 
necessidade de oxigenação do recém-nascido. Desenvolveu icterícia neonatal que regrediu após fototerapia. O defeito cardíaco foi diagnosticado como tetralogia de Fallot, tendo a criança se submetido a cirurgia aos seis meses de idade. A mãe relata a ocorrência de "dois episódios de AVC", secundários ao problema cardíaco. Houve atraso do desenvolvimento neuropsicomotor, tendo andado aos quatro anos de idade. Começou a falar aos cinco anos. Fez correção de criptorquidia unilateral aos quatro anos de idade. No exame físico realizado aos 11 anos e meio, sua estatura foi de $156 \mathrm{~cm}$ (percentil 90), o peso, de $38.700 \mathrm{~g}$ (percentil 50) e o perímetro cefálico, de $52,8 \mathrm{~cm}$ (próximo do percentil 50). Apresentava face triangular com hipoplasia da porção média, hipertelorismo ocular, ponte nasal baixa, nariz bulboso, filtro longo; mãos com encurtamento do $5^{\circ}$ dedo bilateralmente e frouxidão ligamentar interfalângica; frouxidão ligamentar também de cotovelos. Apresentava sopro sistólico importante.

\section{- Padrão de inativação do cromossomo X}

A investigação do padrão de inativação do cromossomo $X$ foi realizada na mãe do probando (II-2 - Figura 9), na tia materna (II-8), ambas portadoras obrigatórias por serem mães de afetados e na prima materna (III-12). Todas apresentaram desvio total de inativação do cromossomo X, (padrão 100:0), reforçando a hipótese de herança ligada ao cromossomo $\mathrm{X}$ nessa família.

\section{- Busca de microrrearranjos no cromossomo $\mathrm{X}$ por array-CGH}

No probando, investigamos a presença de desequilíbrios genômicos submicroscópicos no cromossomo $\mathrm{X}$ pela técnica de array-CGH, utilizando a 
plataforma Cytosure ${ }^{\mathrm{TM}}$, Chromosome X HD microarray 2x105K e não encontramos alteração.

- Mapeamento da região candidata

Os marcadores AR (Xq12 - 66,943,551-66,944,252), DXS1216 (Xq13.1 68,264,353-68,464,720) e DXS986 (Xq21.1 - 79,381,030-79,381,190) foram os únicos que segregaram com a deficiência mental na família, estando o mesmo alelo presente em todos os afetados e nas portadoras obrigatórias (Tabela III). A região candidata de $42 \mathrm{Mb}(\mathrm{Xp11.3} \mathrm{-} \mathrm{Xq21.3)} \mathrm{ficou} \mathrm{delimitada} \mathrm{pelos} \mathrm{marcadores} \mathrm{DXS8080} \mathrm{(44,243,430-}$ $44,243,620)$ e DXS1196 (86,688,618-86,688,830).

\section{- Análise de genes candidatos}

A região candidata delimitada nesta família inclui 22 genes já associados a deficiência mental sindrômica e 10 associados a deficiência mental não sindrômica.

Dentre esses, sequenciamos os genes SYN1 (synapsin I), PQBPI (polyglutamine binding protein 1), SHROOM4 (shroom family member 4), KDM5C (lysine (K)-specific demethylase 5C), HSD17B10 (hydroxysteroid (17-beta) dehydrogenase 10), FGD1 (FYVE, RhoGEF and PH domain containing 1) e OPHN1 (oligophrenin 1) e não encontramos nenhuma alteração considerada patogênica. 
Tabela III: Marcadores moleculares do tipo microssatélite analisados na Família 3: localização no cromossomo X - Mb (GRCh37, hg 19), banda cromossômica e alelos.

\begin{tabular}{|c|c|c|c|c|c|c|c|c|c|c|}
\hline Marcador & Mb & Banda & Het. & II-2 & II-8 & III-5 & III-6 & III-10 & III-11 & III-12 \\
\hline DXS1060 & $5,409,853-5,409,998$ & Xp22.33 & 0.84 & $1 / 2$ & $2 / 2$ & 2 & 1 & 2 & 2 & $2 / 2$ \\
\hline DXS1223 & $8,493,939-8,494,096$ & Xp22.31 & 0,77 & $1 / 3$ & $1 / 4$ & 1 & 3 & 4 & 4 & $1 / 2$ \\
\hline DXS8051 & $9,499,372-9,499,530$ & Xp22.32 & 0.88 & $2 / 3$ & $3 / 3$ & 3 & 2 & 3 & 3 & $1 / 3$ \\
\hline DXS987 & $14,709,303-14,709,562$ & $\mathrm{Xp} 22.31$ & 0.83 & $2 / 3$ & $2 / 4$ & 2 & 3 & 2 & 4 & $1 / 4$ \\
\hline DXS1226 & $22,847,422-23,047,802$ & $\mathrm{Xp} 22.11$ & 0.84 & $1 / 2$ & $1 / 2$ & 1 & 2 & 1 & 2 & $2 / 3$ \\
\hline DXS1061 & $27,442,092-27,442,332$ & $\mathrm{Xp} 21.3$ & 0,78 & $1 / 2$ & $1 / 3$ & 1 & 2 & 1 & 3 & $1 / 3$ \\
\hline DXS1214 & $31,260,993-31,261,085$ & $\mathrm{Xp} 21.2$ & 0.79 & $1 / 2$ & $1 / 2$ & 2 & 1 & 2 & $\mathbf{1}$ & $1 / 3$ \\
\hline DXS1068 & $38,908,227-38,908,332$ & Xp11.4 & 0.79 & $1 / 2$ & $1 / 2$ & 1 & 2 & 1 & 2 & $1 / 2$ \\
\hline DXS8015 & $39,784,176-39,784,361$ & Xp11.4 & 0.77 & $1 / 3$ & $1 / 3$ & 3 & 1 & 3 & 1 & $1 / 2$ \\
\hline DXS993 & $41,147,683-41,147,988$ & Xp11.4 & 0.79 & $1 / 1$ & $1 / 1$ & 1 & 1 & 1 & 1 & $1 / 2$ \\
\hline DXS8080 & $44,243,430-44,243,620$ & Xp11.3 & 0,69 & $1 / 2$ & $1 / 2$ & 1 & 2 & 1 & 2 & $2 / 3$ \\
\hline DXS1055 & $46,426,374-46,426,460$ & $\mathrm{Xp} 11.23$ & 0,68 & $1 / 1$ & $1 / 1$ & 1 & 1 & 1 & 1 & $1 / 1$ \\
\hline DXS1039 & $49,458,560-49,458,698$ & $\mathrm{Xp} 11.23$ & 0,56 & $1 / 1$ & $1 / 1$ & 1 & 1 & 1 & 1 & $1 / 2$ \\
\hline DXS991 & $55,519,052-55,519,331$ & $\mathrm{Xp} 11.21$ & 0.80 & $2 / 2$ & $2 / 2$ & 2 & 2 & 2 & 2 & $1 / 2$ \\
\hline $\mathbf{A R}$ & $66,943,551-66,944,252$ & $\mathrm{Xq12}$ & 0,90 & $2 / 3^{(M)}$ & $2 / 3^{(M)}$ & 3 & 3 & 2 & 3 & $1 / 3^{(M)}$ \\
\hline DXS1216 & $68,264,353-68,464,720$ & Xq13.1 & 0,68 & $2 / 3$ & $2 / 3$ & 3 & 3 & 2 & 3 & $3 / 3$ \\
\hline DXS986 & $79,381,030-79,381,190$ & $\mathrm{Xq} 21.1$ & 0.77 & $2 / 3$ & $2 / 3$ & 2 & 2 & 3 & 2 & $1 / 2$ \\
\hline DXS1196 & $86,688,618-86,688,830$ & $\mathrm{Xq} 21.31$ & 0,79 & $1 / 2$ & $2 / 3$ & 1 & 1 & 2 & 3 & $2 / 3$ \\
\hline DXS1217 & $88,395,845-88,396,079$ & $\mathrm{Xq} 21.31$ & 0.60 & $1 / 1$ & $1 / 1$ & 1 & 1 & 1 & 1 & $1 / 1$ \\
\hline DXS990 & $93,000,646-93,000,819$ & $\mathrm{Xq} 21.32$ & 0.74 & $1 / 3$ & $2 / 3$ & 1 & 1 & 3 & 2 & $1 / 2$ \\
\hline DXS8077 & $95,275,368-95,275,474$ & $\mathrm{Xq} 21.33$ & 0.72 & $1 / 1$ & $1 / 2$ & 1 & 1 & 1 & 2 & $2 / 3$ \\
\hline DXS1106 & $102,732,067-102,732,245$ & $\mathrm{Xq} 22.2$ & 0.67 & $2 / 2$ & $2 / 3$ & 2 & 2 & 2 & 3 & $1 / 3$ \\
\hline DXS1059 & $111,325,975-111,326,164$ & $\mathrm{Xq} 23$ & 0,71 & $2 / 2$ & $1 / 2$ & 2 & 2 & 2 & 1 & $1 / 3$ \\
\hline DXS8055 & $114,654,942-114,655,104$ & $\mathrm{Xq} 23$ & 0.65 & $1 / 1$ & $1 / 2$ & 1 & 1 & 1 & 2 & $2 / 2$ \\
\hline DXS8064 & $117,272,909-117,273,123$ & $\mathrm{Xq} 24$ & 0.60 & $2 / 2$ & $2 / 2$ & 2 & 2 & 2 & 2 & $1 / 2$ \\
\hline DXS1001 & $119,836,668-119,836,873$ & $\mathrm{Xq} 24$ & 0.82 & $2 / 3$ & $3 / 4$ & 2 & 3 & 3 & 4 & $1 / 4$ \\
\hline DXS1047 & $129,075,320-129,075,521$ & $\mathrm{Xq} 26.1$ & 0.81 & $1 / 2$ & $1 / 2$ & 2 & 1 & 1 & 2 & $2 / 3$ \\
\hline DXS1062 & $137,302,993-137,303,228$ & Xq26.3 & 0.75 & $1 / 3$ & $1 / 3$ & 1 & 3 & 3 & 1 & $1 / 2$ \\
\hline DXS1227 & $140,802,415-140,802,588$ & $\mathrm{Xq} 27.2$ & 0.73 & $1 / 3$ & $1 / 3$ & 3 & 1 & 1 & 3 & $1 / 2$ \\
\hline DXS8043 & $144,028,522-144,028,706$ & $\mathrm{Xq} 27.3$ & 0.80 & $2 / 3$ & $2 / 3$ & 3 & 2 & 2 & 3 & $1 / 2$ \\
\hline DXS8045 & $145,512,050-145,512,268$ & $\mathrm{Xq} 27.3$ & 0,54 & $1 / 2$ & $1 / 2$ & 1 & 2 & 2 & 1 & $2 / 3$ \\
\hline DXS8091 & $147,602,856-147,602,958$ & $\mathrm{Xq} 28$ & 0.78 & $1 / 3$ & $1 / 3$ & 1 & 3 & 3 & 1 & $2 / 3$ \\
\hline DXS1073 & $153,828,908-153,829,128$ & $\mathrm{Xq} 28$ & 0.80 & $1 / 3$ & $1 / 3$ & 1 & 3 & 3 & 1 & $2 / 3$ \\
\hline
\end{tabular}

Azul - Marcadores segregam com a doença

Verde - Marcadores não segregam com a doença

Amarelo - Marcadores não informativos

$\left({ }^{\mathrm{M}}\right)$ Alelo metilado

A região delimitada para o mapeamento da DM está realçada em negrito 


\section{- Sequenciamento do exoma}

Amostra de DNA do probando foi submetida ao sequenciamento do exoma pela OGT e depois de utilizados os critérios para seleção das variantes consideradas candidatas ao quadro clínico, conforme descrito em Métodos (III.2.4), ficamos com um único gene, KIAA2022:

Estudando uma família com dois afetados por deficiência mental; um tio e um sobrinho, cujas mães eram fenotipicamente normais, Cantagrel et al. (2004) encontraram uma inversão pericêntrica no cromossomo $X ; \operatorname{inv}(X)(p 22.3)(q 13.2)$, segregando com a deficiência mental na família. A inversão rompia dois genes: KIAA2022 e P2RY8 (pyrimidinergic receptor P2Y, G protein-coupled, 8). Os autores determinaram a estrutura e o padrão de expressão desses dois genes. P2RY8 está localizado no segmento pseudoautossômico do cromossomo X. Essa localização, aliada ao fenótipo normal das mulheres portadoras, indicou que a haploinsuficiência do gene não deveria ser causa de doença. Além disso, Cantagrel et al. (2004) verificaram que o gene não se expressa em cérebro, não podendo assim estar relacionado com deficiência mental. Os autores determinaram que o gene KIAA2022 contém quatro exons estendendo-se por $192 \mathrm{~kb}$; o intron 1 tem $180 \mathrm{~kb}$ e o exon 3 com mais de $4 \mathrm{~kb}$, contém a maior parte da região codificadora. Os autores mostraram também que o gene KIAA2022 é altamente expresso em cérebro fetal e adulto, predominantemente no córtex cerebral e no cerebelo, no adulto; em outros tecidos a expressão tem menor intensidade. Os homens portadores da inversão não expressavam KIAA2022. Concluíram, assim, que a ausência do produto do gene KIAA2022 era responsável pelo quadro clínico de seus pacientes. Os afetados apresentavam hipotonia neonatal, importante atraso do desenvolvimento neuromotor, tendo andado após os três anos, ausência de fala, 
quadriparesia progressiva e refluxo gastroesofágico; os movimentos estereotipados e o contato visual pobre levaram ao diagnóstico de autismo. Aos 13 meses de idade o propósito apresentou um episódio de convulsão, havendo recorrência, sob medicação, no contexto de febre alta; o EEG indicou acentuada disritmia lenta bilateral. Apresentou refluxo gastresofágico e, aos dois anos de idade, uma úlcera gástrica foi diagnosticada. Desenvolveu quadriparesia espástica e com três anos de idade passou por cirurgia para correção de pés calcaneovalgos. Sentou-se sem apoio aos 15 meses de idade e andou aos três anos. Aos dois anos, passou a apresentar movimentos estereotipados das mãos e interação social pobre, sugestiva de autismo. Não desenvolveu linguagem e, examinado aos doze anos, apresentava deficiência mental profunda com movimentos estereotipados permanentes. No exame clínico, foi notado dismorfismo facial discreto, apresentando filtro curto, nariz curto com ponta grossa; tinha escroto em cachecol e quadriparesia espástica, com perda de massa muscular das pernas. Imagens de ressonância magnética indicaram atrofia cerebral moderada.

Em estudo posterior, Cantagrel et al. (2009) mostraram que o gene Kiaa2022 de camundongos é expresso no cérebro em desenvolvimento e que pode desempenhar papel na maturação pós mitótica dos neurônios. Demonstraram que o gene Kiaa2022 é preferencialmente expresso no sistema nervoso central e que o seu transcrito é altamente expresso em neurônios pós-mitóticos.

Na Família 3 aqui estudada, cujos pacientes apresentam deficiência mental associada a outros sinais (Figura 9), detectamos uma mutação missense no exon 2 do gene KIAA2022, c.262G>A, que resulta na substituição do ácido glutâmico por lisina (E88K), segregando com a deficiência mental. A mãe do probando e a tia materna, mães de afetados (II-2 e II-8, respectivamente) e a prima materna do probando (III-12), todas com desvio total de inativação do cromossomo X (padrão 100:0), são heterozigóticas 
quanto à mutação c.262G>A. O irmão clinicamente normal de afetado (III-10) não é portador da mutação (Figura 10).

A mutação substitui um ácido glutâmico conservado entre Macaca mulatta, Bos taurus, Canis lupus, Pan troglodytes e Homo sapiens. O aminoácido não é conservado em $M$. musculus e $R$. norvegicus, porém essas espécies têm, na mesma posição, o ácido aspártico, que, como o ácido glutâmico, apresenta dois grupos carboxílicos e um grupo amina, sendo também um aminoácido ácido (Figura 11). 


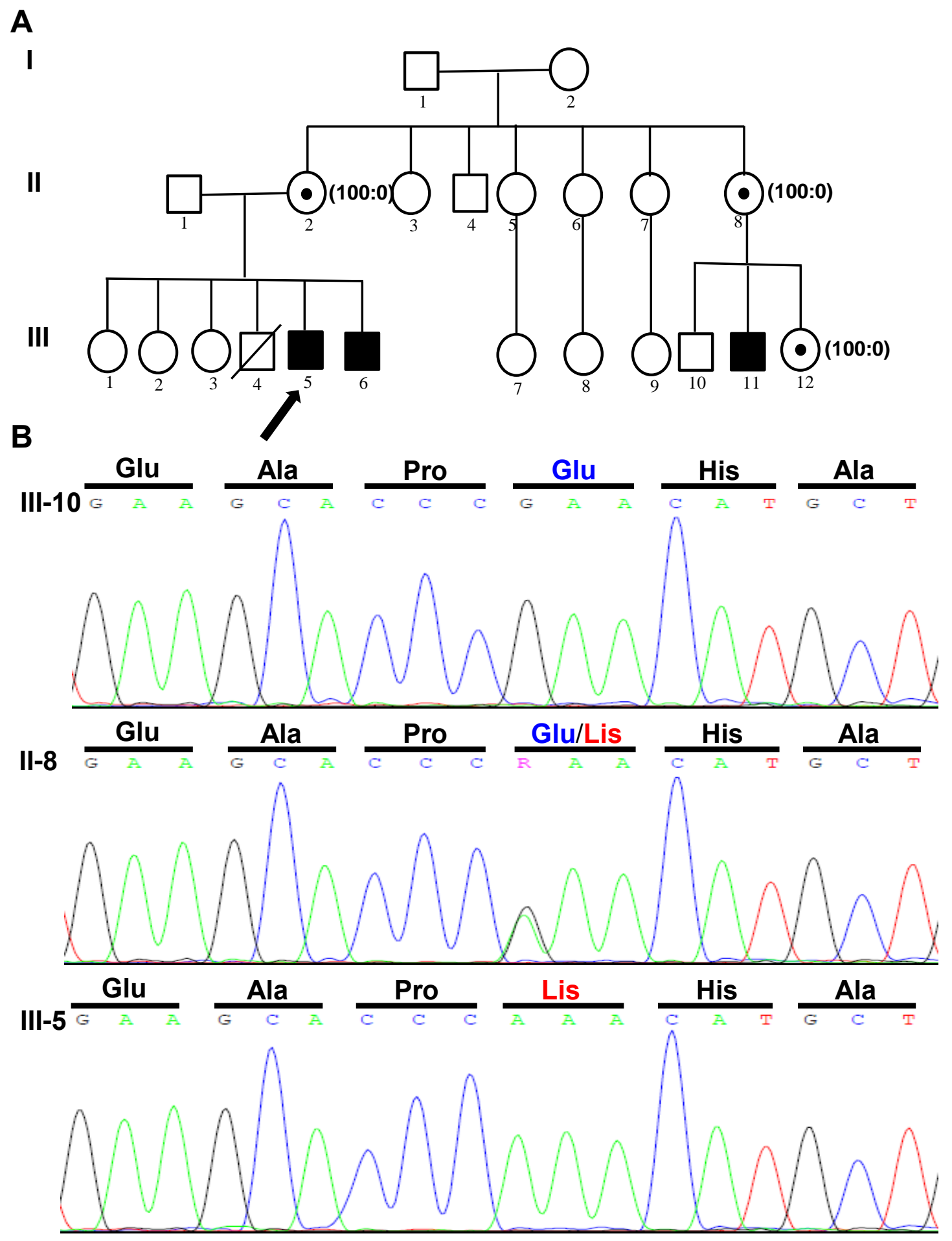

Figura 10: Mutação missense c.262G>A no exon 2 do gene KIAA2022. (A) Heredograma da Família 3, mostrando o desvio total da inativação do cromossomo $\mathrm{X}$ nas mulheres portadoras. (B) Transição G>A no exon 2 do gene KIAA2022, resultando na substituição de ácido glutâmico por lisina (E88K): cromatogramas das fitas senso de um indivíduo normal (III-10), uma mulher portadora da mutação (II-8) e um indivíduo afetado (III-5). 


\begin{tabular}{|lcll|}
\hline M. musculus & 59 & MFPRGLLPPPSKKPCMQSPPSPLALIEAPDHSANSASVNAISLTSGVAKG & 108 \\
R. norvegicus & 59 & MFPRGLLPLPSKKPCMQSPPSPLGLIEAPDHSATGASVNAISLTSGVAKG & 108 \\
M. mulatta & 59 & MYPRGLLPLPSKKSCMQSPPSPLGLIEAPEHAANSASVNAISLTSGIAKG & 108 \\
B. taurus & 59 & MYPRGLLPLPSKKPCMQSPPSPLGLIEAPEHAANSASVNAISLTSGVAKG & 108 \\
C. lupus & 59 & MYPRGLLPLSSKKPCMQSPPSPLGLIEAPEHAANSASVNAISLTSGVAKS & 108 \\
P. troglodytes & 101 & MYPRGLLPLPSKKPCMQSPPSPLGLIEAPEHAANSASVNAISLTSGIAKG & 150 \\
H. sapiens & 59 & MYPRGLLPLPSKKPCMQSPPSPLGLIEAPEHAANSASVNAISLTSGIAKG & 108 \\
Família 3 & 59 & MYPRGLLPLPSKKPCMQSPPSPLGLIEAPKHAANSASVNAISLTSGIAKG & 108 \\
\hline
\end{tabular}

Figura 11: Alinhamento das sequências de 50 aminoácidos da proteína KIAA2022 de mamíferos ao redor do ácido glutâmico substituído - E88K mostrando o alto grau de similaridade entre as espécies. É interessante notar que, apesar das espécies Mus musculus e Rattus norvegicus não conservarem o ácido glutâmico na posição 88, substituíram por outro aminoácido que também é ácido e química e estruturalmente semelhante ao ácido glutâmico. Em azul, o ácido glutâmico substituído por lisina, em vermelho. Em verde, o ácido aspártico na posição $88 \mathrm{em} \mathrm{M}$. musculus e R. norvegicus. A sequência de aminoácidos das proteínas KIAA2022 foi obtida do HomoloGene, NCBI (http://www.ncbi.nlm.nih.gov/). 
O ácido glutâmico, substituído na família aqui descrita é um aminoácido que possui grupo carboxila em sua cadeia lateral, além daquele presente em todos os aminoácidos, portanto é ácido. A mutação substitui o acido glutâmico por lisina (E88K), um aminoácido que possui dois grupos amina, sendo dessa forma básico. De acordo com o HomoloGene (NCBI), verificamos que o ácido glutâmico na posição 88 é mantido entre os mamíferos, com exceção das espécies $M$. musculus e $R$. norvegicus, que apesar de não conservarem o ácido glutâmico, apresentam nessa posição o ácido aspártico, um aminoácido quimicamente ácido e semelhante ao ácido glutâmico, dando indícios de que um aminoácido com cargas negativas seja importante na posição 88 da proteína KIAA2022. A lisina difere bastante em sua composição química e estrutura (Figura 12). A diferença na estrutura e composição entre os aminoácidos pode alterar a estrutura tridimensional da proteína, prejudicando sua função.

O conjunto de dados aqui apresentados indica que a mutação missense c.262G>A, levando á substituição de ácido glutâmico por lisina na proteína KIAA2022, seja responsável pelo quadro clínico dos afetados por deficiência mental na Família 3.

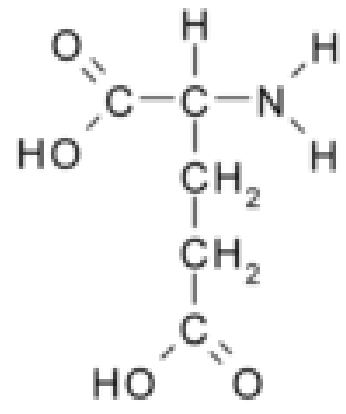

Ácido glutâmico

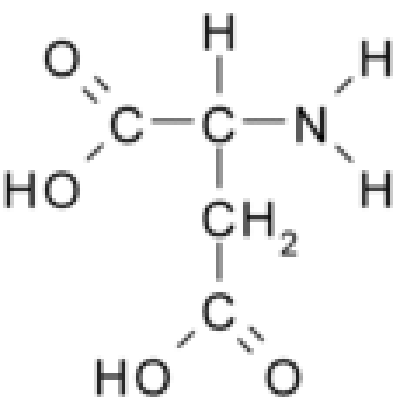

Ácido aspártico

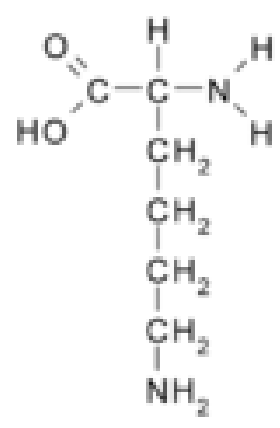

Lisina

Figura 12: Estrutura e composição química do ácido glutâmico, do ácido aspártico e da lisina. Nos afetados por deficiência mental da Família 3, encontramos uma mutação missense que leva à substituição de ácido glutâmico por lisina (E88K), segregando com a doença na família. $\mathrm{O}$ aminoácido substituído é conservado entre os mamíferos, porém Mus musculus e Rattus norvegicus apresentam um ácido aspártico na posição 88 da cadeia polipeptídica. 


\section{IV.1.4. FAMÍLIA 4}

A Família 4 (Figura 13) foi averiguada pela equipe do Dr. Charles Marques Lourenço do Hospital das Clínicas - Faculdade de Medicina de Ribeirão Preto - USP. Os pacientes se distribuem na família de acordo com o padrão de herança recessiva ligada ao X. O exame cromossômico realizado no probando, após bandamento G, não revelou alteração. A síndrome do X frágil foi afastada por PCR (Haddad et al., 1996), no probando (III-1), em seu irmão (III-2), em seus primos maternos em primeiro grau (III-5, III-6 e III-8) e em seu primo materno em segundo grau (IV-1). Os afetados apresentam deficiência mental e microcefalia. O probando e seu irmão foram submetidos a ressonância magnética que revelou, em ambos, malformação de DandyWalker e alteração de sinal da substância branca periventricular.

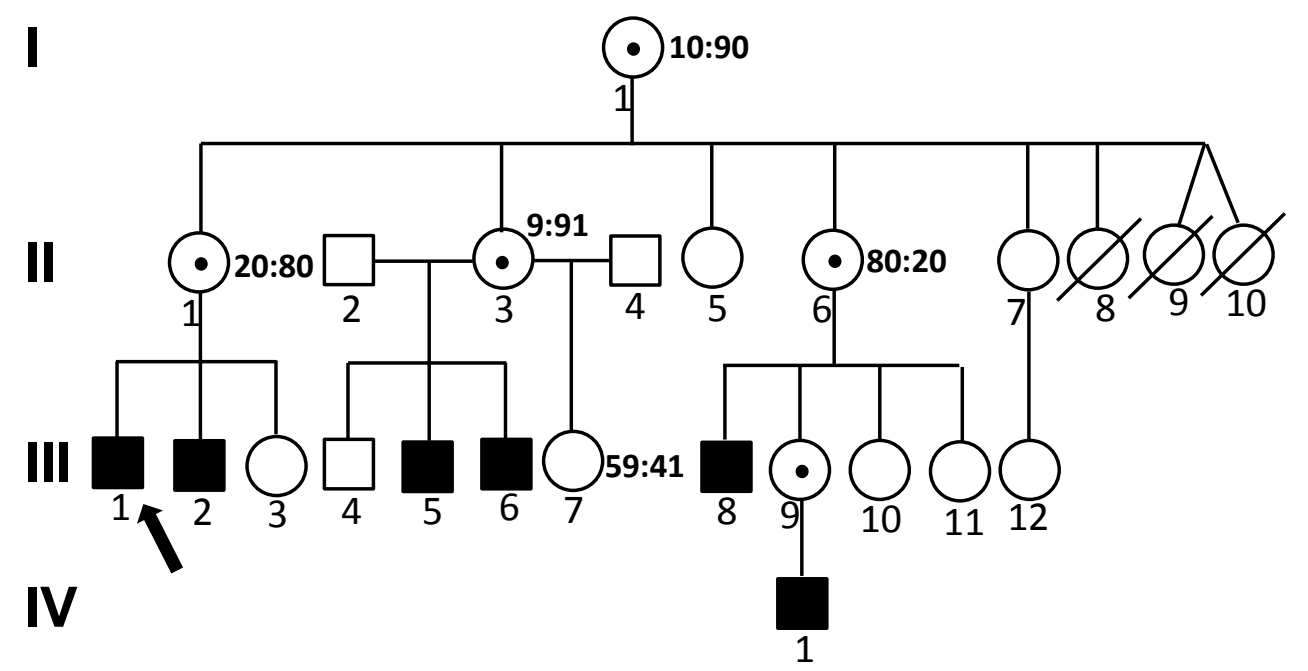

Figura 13. Família 4: Genealogia com afetados por deficiência mental, que ocorrem num padrão compatível com a herança ligada ao X. O padrão de inativação do cromossomo X está indicado ao lado de cada mulher analisada. 


\section{- Padrão de inativação do cromossomo X}

A investigação do padrão de inativação do cromossomo $\mathrm{X}$ foi realizada em dez mulheres da família (Tabela IV). As mães de afetados informativas no teste (I-1, II-1, II-3, II-6), todas apresentaram padrões de inativação com desvios, presentes em $12 \%$ (II-1 e II-6) ou 3,5\%-4,0\% (I-1 e II-3) das mulheres da população normal (probabilidades calculadas com base no estudo de Amos-Landgraf et al., 2006). Dentre as cinco irmãs de afetados analisadas, sem filhos afetados, apenas III-3 foi heterozigótica quanto à repetição $\mathrm{CAG}$ do gene $A R$, permitindo determinar o padrão de inativação (padrão 59:41, dentro do esperado, considerando a inativação casual do cromossomo $\mathrm{X}$ ).

Tabela IV: Padrão de inativação do cromossomo X nas mulheres da Família 4.

\begin{tabular}{ccc}
\hline Mulheres examinadas & Padrão de inativação & P* \\
\hline I-1 & $10: 90$ & 0,039 \\
II-1 & $20: 80$ & 0,12 \\
II-3 & $9: 91$ & 0,035 \\
II-6 & $80: 20$ & 0,12 \\
III-3 & Homozigota no locus AR & - \\
III-7 & $59: 41$ & 0,64 \\
III-9 & Homozigota no locus $A R$ & - \\
III-10 & Homozigota no locus $A R$ & - \\
III-11 & Homozigota no locus $A R$ & - \\
\hline
\end{tabular}

* Probabilidades calculadas com base na distribuição dos padrões de inativação do cromossomo $\mathrm{X}$ em mulheres adultas da população geral analisadas por Amos-Landgraf et al. (2006); Paulo A. Otto (comunicação pessoal). 
- Mapeamento da região candidata

Utilizando 36 marcadores moleculares do tipo microssatélites ao longo do cromossomo X (Tabela V), verificamos que os marcadores DXS8045 $(145,512,050$ 145,512,268) e DXS1073 $(153,828,908-153,829,128)$ segregam com a DM. A região candidata de 13,5 Mb (Xq27.3 - Xq28) está delimitada proximalmente pelo marcador DXS1227 (140,802,415-140,802,588) e distalmente pelo último gene mapeado no braço longo do cromossomo X, MTCP1 (mature T-cell proliferation 1; 154,289,897$154,376,212)$. 
Tabela V: Marcadores moleculares do tipo microssatélite analisados: localização no cromossomo X - Mb (GRCh37, hg 19) e banda cromossômica - e alelos de cada individuo.

\begin{tabular}{|c|c|c|c|c|c|c|c|c|c|c|c|c|c|c|c|c|c|c|c|}
\hline Marcador & Mb & Banda & Het. & I-1 & II-1 & III-3 & II-6 & III-1 & III-2 & III-3 & III-4 & III-5 & III-6 & III-7 & III-8 & III-9 & III-10 & III-11 & IV-1 \\
\hline DXS1060 & $5,409,853-5,409,998$ & Xp22.32 & 0.84 & $3 / 4$ & $3 / 5 \#$ & $\# 1 / 4$ & $3 / 7 \#$ & 3 & 5 & $3 / 5$ & 4 & 1 & 1 & $1 / 6$ & 7 & $3 / 6 \#$ & $2 / 7 \#$ & $2 / 7 \#$ & $?$ \\
\hline DXS1223 & $8,493,939-8,494,096$ & $\mathrm{Xp} 22.31$ & 0,77 & $1 / 3$ & $3 / 4$ & $1 / 1 \#$ & $3 / 4$ & 3 & 4 & $3 / 3$ & 1 & 1 & 1 & $?$ & $?$ & $\# 2 / 3$ & $\# 1 / 4$ & $?$ & 3 \\
\hline DXS8051 & $9,499,372-9,499,530$ & Xp22.31 & 0,88 & $1 / 2$ & $2 / 2$ & $1 / 1 \#$ & $2 / 2$ & 2 & 2 & $2 / 2$ & 1 & 1 & 1 & $1 / 3$ & 2 & $2 / 2$ & $2 / 2$ & $2 / 2$ & $?$ \\
\hline DXS7108 & $10,192,237-10,192,484$ & $\mathrm{Xp} 22.2$ & 0.74 & $2 / 6$ & $?$ & $\# 1 / 6$ & $2 / 4 \#$ & 4 & 4 & $2 / 5$ & 6 & 1 & 1 & $1 / 3$ & 2 & $\# 1 / 2$ & 4/5\# & $4 / 5 \#$ & 2 \\
\hline DXS987 & $14,709,303-14,709,562$ & Xp22.2 & 0,83 & $1 / 6$ & $\# 3 / 6$ & $1 / 4 \#$ & $\# 2 / 6$ & 3 & 3 & $3 / 6$ & 1 & 1 & 4 & $4 / 5$ & 6 & 6/6\# & $2 / 2 \#$ & $2 / 2 \#$ & 6 \\
\hline DXS1226 & $22,847,422-23,047,802$ & $\mathrm{Xp} 22.11$ & 0.84 & $5 / 6$ & $1 / 5$ & $2 / 6$ & $5 / 5$ & 1 & $?$ & $1 / 5$ & 6 & 6 & 2 & $2 / 2$ & 5 & $\# 4 / 5$ & $\# 3 / 5$ & $\# 3 / 5$ & 5 \\
\hline DXS1061 & $27,442,092-27,442,332$ & $\mathrm{Xp} 21.3$ & 0,78 & $2 / 2$ & $1 / 2$ & $2 / 3$ & $2 / 4$ & 1 & 2 & $2 / 4$ & 2 & 2 & 3 & $3 / 3$ & 2 & 2/3\# & 4/4\# & $4 / 4 \#$ & 2 \\
\hline DXS1214 & $31,260,993-31,261,085$ & $\mathrm{Xp} 21.2$ & 0,79 & $1 / 2$ & $2 / 2 \#$ & $1 / 1 \#$ & $2 / 2 \#$ & 2 & 2 & $2 / 2$ & 1 & 1 & 1 & $1 / 2$ & 2 & $\# 1 / 2$ & $2 / 3 \#$ & 2/3\# & $?$ \\
\hline DXS8090 & $36,953,961-36,954,130$ & Xp21.1 & 0,77 & $2 / 2$ & $2 / 2$ & $?$ & $2 / 2$ & $?$ & 2 & $?$ & $?$ & $?$ & $?$ & $?$ & 2 & $2 / 3 \#$ & $\# 1 / 2$ & $\# 1 / 2$ & 3 \\
\hline DXS1068 & $38,908,227-38,908,332$ & Xp11.4 & 0,79 & $2 / 2$ & $\# 1 / 2$ & $2 / 2 \#$ & 2/4\# & 1 & 2 & $1 / 3$ & 2 & 2 & 2 & $2 / 5$ & 2 & $\# 1 / 2$ & 4/4\# & 4/4\# & $?$ \\
\hline DXS8015 & $39,784,176-39,784,361$ & Xp11.4 & 0,77 & $3 / 4$ & $3 / 5 \#$ & $\# 2 / 4$ & $\# 2 / 3$ & 5 & 3 & $4 / 5$ & 4 & 4 & 4 & $1 / 2$ & 3 & $3 / 5$ & $2 / 5$ & $2 / 5$ & 5 \\
\hline DXS993 & $41,147,683-41,147,988$ & Xp11.4 & 0.79 & $2 / 4$ & 2/3\# & $4 / 4 \#$ & $\# 1 / 2$ & 3 & $?$ & $2 / 3$ & 4 & 4 & 4 & $1 / 4$ & 2 & $1 / 2$ & $1 / 4$ & $1 / 4$ & $?$ \\
\hline DXS8080 & $44,243,430-44,243,620$ & Xp11.3 & 0,69 & $1 / 2$ & 1/3\# & $1 / 2$ & $1 / 5 \#$ & 3 & 1 & $3 / 6$ & 2 & 2 & 2 & $1 / 2$ & 1 & $1 / 4$ & $4 / 5$ & $4 / 5$ & 4 \\
\hline DXS1055 & $46,426,374-46,426,460$ & $\mathrm{Xp} 11.23$ & 0,68 & $1 / 3$ & $\# 2 / 3$ & $1 / 3$ & $1 / 3$ & 2 & 3 & $2 / 3$ & 3 & 3 & 3 & $1 / 2$ & 1 & $1 / 2$ & $2 / 3$ & $2 / 3$ & $?$ \\
\hline DXS1039 & $49,458,560-49,458,698$ & $\mathrm{Xp} 11.23$ & 0,56 & $1 / 3$ & $1 / 3$ & $1 / 3$ & $3 / 3$ & 3 & 1 & $1 / 3$ & 1 & 1 & 1 & $2 / 3$ & 3 & $\# 2 / 3$ & 3/3\# & 3/3\# & 2 \\
\hline DXS991 & $55,519,052-55,519,331$ & Xp11.21 & 0.80 & $3 / 3$ & $\# 1 / 3$ & $3 / 5 \#$ & $\# 2 / 3$ & 1 & 3 & $1 / 2$ & 3 & 3 & 3 & $4 / 5$ & 3 & $2 / 3$ & $\# 1 / 2$ & $\# 1 / 2$ & $?$ \\
\hline $\mathbf{A R}$ & $66,943,551-66,944,252$ & $\mathrm{Xq} 12$ & 0,90 & $1 / 4^{(M)}$ & $\# \mathbf{3 / 4} \mathbf{4}^{(\mathrm{M})}$ & $3 / 4^{(M)}$ & (M) $1 / 2 \#$ & 3 & 4 & $3 / 3$ & 4 & 4 & 4 & $2 / 3$ & $?$ & $2 / 2$ & $2 / 2$ & $2 / 2$ & $?$ \\
\hline DXS1216 & $68,264,353-68,464,720$ & $\mathrm{Xq} 13.1$ & 0,68 & $2 / 3$ & $\# 1 / 3$ & $2 / 3$ & $2 / 2 \#$ & 1 & 3 & $1 / 1$ & 3 & 3 & 3 & $2 / 3$ & 2 & $2 / 4 \#$ & $\# 1 / 2$ & $\# 1 / 2$ & $?$ \\
\hline DXS986 & $79,381,030-79,381,190$ & $\mathrm{Xq} 21.1$ & 0.77 & $1 / 6$ & $1 / 4 \#$ & $1 / 3 \#$ & $\# 2 / 6$ & 4 & $\mathbf{1}$ & $2 / 4$ & 1 & 1 & 1 & $3 / 5$ & 6 & $2 / 3 \#$ & $2 / 6$ & 2/2\# & 3 \\
\hline DXS1196 & $86,688,618-86,688,830$ & $\mathrm{Xq} 21.31$ & 0,79 & $1 / 2$ & $1 / 2$ & $1 / 5 \#$ & $1 / 2$ & 2 & 1 & $2 / 4$ & 1 & 1 & 1 & $1 / 5$ & 2 & $1 / 3 \#$ & $1 / 2$ & 1/1\# & $?$ \\
\hline DXS1217 & $88,395,845-88,396,079$ & $\mathrm{Xq} 21.31$ & 0,60 & $3 / 5$ & $2 / 3$ & $2 / 3$ & $2 / 5$ & 2 & 3 & $2 / 2$ & 3 & 3 & 3 & $1 / 2$ & 5 & $2 / 2 \#$ & $\# 4 / 5$ & $\# 4 / 5$ & $?$ \\
\hline
\end{tabular}

Verde - Marcadores que não segregam com a DM

\section{Continua}

? - Não genotipado 
Tabela V: Continuação.

\begin{tabular}{|c|c|c|c|c|c|c|c|c|c|c|c|c|c|c|c|c|c|c|c|}
\hline Marcador & Mb & Banda & Het. & I-1 & II-1 & II-3 & II-6 & III-1 & III-2 & III-3 & III-4 & III-5 & III-6 & III-7 & III-8 & III-9 & III-10 & III-11 & IV-1 \\
\hline DXS990 & $93,000,646-93,000,819$ & $\mathrm{Xq} 21.32$ & 0.74 & $1 / 4$ & $1 / 5 \#$ & $1 / 2 \#$ & $\# 3 / 4$ & 5 & 1 & $3 / 5$ & 1 & 1 & 1 & $2 / 2$ & 4 & $3 / 5 \#$ & 4/4\# & $4 / 4 \#$ & $?$ \\
\hline DXS8077 & $95,275,368-95,275,474$ & $\mathrm{Xq} 21.33$ & - & $2 / 5$ & $2 / 2 \#$ & 2/3\# & $2 / 5$ & 2 & 2 & $2 / 2$ & 2 & 2 & 2 & $1 / 3$ & 5 & $2 / 4 \#$ & $2 / 5$ & $2 / 5$ & $?$ \\
\hline DXS1106 & $102,732,067-102,732,245$ & $\mathrm{Xq} 22.2$ & 0.67 & $2 / 3$ & $2 / 3$ & $3 / 4 \#$ & $2 / 2 \#$ & 2 & 3 & $2 / 5$ & 3 & 3 & 3 & $1 / 4$ & 2 & $\# 1 / 2$ & $2 / 2 \#$ & $2 / 2 \#$ & 1 \\
\hline DXS1059 & $111,325,975-111,326,164$ & $\mathrm{Xq} 23$ & 0,71 & $3 / 3$ & $\# 1 / 3$ & $\# 2 / 3$ & $3 / 5 \#$ & 1 & 3 & $1 / 1$ & 3 & 3 & 3 & $2 / 3$ & 3 & $4 / 5$ & $3 / 4$ & $3 / 4$ & $?$ \\
\hline DXS8055 & $114,654,942-114,655,104$ & $\mathrm{Xq} 23$ & 0.65 & $2 / 2$ & $\# 1 / 2$ & $2 / 2 \#$ & $1 / 2$ & 1 & 2 & $1 / 4$ & 2 & 2 & 2 & $2 / 6$ & 2 & $1 / 5 \#$ & 2/3\# & $2 / 3 \#$ & 5 \\
\hline DXS8064 & $117,272,909-117,273,123$ & $\mathrm{Xq} 24$ & 0,60 & $1 / 2$ & 1/1\# & $1 / 1$ & $1 / 2$ & 1 & 1 & $?$ & 1 & 1 & 1 & $1 / 1$ & 2 & $1 / 1$ & $1 / 1$ & $1 / 2$ & 1 \\
\hline DXS1001 & $119,836,668-119,836,873$ & $\mathrm{Xq} 24$ & 0,82 & $2 / 6$ & $\# 1 / 2$ & $2 / 4 \#$ & $\# 5 / 6$ & 2 & 2 & $1 / 3$ & 2 & 2 & 4 & $3 / 4$ & 6 & $\# 4 / 5$ & $\# 3 / 5$ & $\# 3 / 6$ & $?$ \\
\hline DXS1047 & $129,075,320-129,075,521$ & Xq26.1 & 0,81 & $1 / 4$ & 1/3\# & $1 / 6 \#$ & 1/5\# & 1 & 1 & $3 / 3$ & 1 & 1 & 6 & $5 / 6$ & 1 & $\# 2 / 5$ & 5/5\# & 1/5\# & 5 \\
\hline DXS1062 & $137,302,993-137,303,228$ & Xq26.3 & 0.75 & $1 / 2$ & $2 / 3 \#$ & $2 / 5 \#$ & $1 / 2$ & 2 & 2 & $3 / 3$ & 5 & 2 & 5 & $2 / 5$ & 2 & $1 / 4$ & $1 / 4$ & $2 / 4$ & 1 \\
\hline DXS1227 & $140,802,415-140,802,588$ & $\mathrm{Xq} 27.2$ & 0.73 & $2 / 3$ & 2/2\# & $\# 1 / 2$ & $2 / 3$ & 2 & 2 & $1 / 2$ & 1 & 2 & 1 & $1 / 1$ & 2 & $2 / 4$ & $3 / 4$ & $2 / 4$ & $?$ \\
\hline DXS8043 & $144,028,522-144,028,706$ & Xq27.3 & 0.80 & $1 / 3$ & $1 / 3$ & $1 / 4 \#$ & 1/5\# & 1 & 1 & $?$ & 4 & 1 & 1 & $2 / 4$ & 1 & 1/3\# & 5/5\# & 1/5\# & 1 \\
\hline DXS8045 & $145,512,050-145,512,268$ & $\mathrm{Xq} 27.3$ & 0,54 & $1 / 3$ & $1 / 2 \#$ & $1 / 3$ & $1 / 5 \#$ & 1 & 1 & $2 / 4$ & 3 & 1 & 1 & $3 / 3$ & 1 & $1 / 4$ & $4 / 5$ & $1 / 4$ & 1 \\
\hline DXS998 & $146,607,898-146,608,097$ & $\mathrm{Xq} 27.3$ & 0,58 & $1 / 3$ & $1 / 3$ & $1 / 3$ & $\# 2 / 3$ & 3 & 3 & $1 / 1$ & 1 & 3 & 3 & $1 / 1$ & 3 & $1 / 3$ & $1 / 2$ & $1 / 3$ & 3 \\
\hline DXS8091 & $147,602,856-147,602,958$ & $\mathrm{Xq} 28$ & 0.78 & $3 / 3$ & $\# 1 / 3$ & $3 / 3 \#$ & $3 / 4 \#$ & 3 & 3 & $1 / 5$ & 3 & 3 & 3 & $2 / 3$ & 3 & $2 / 3$ & $2 / 4$ & $2 / 3$ & 3 \\
\hline DXS1073 & $153,828,908-153,829,128$ & $\mathrm{Xq} 28$ & 0.80 & $1 / 3$ & $3 / 6 \#$ & $3 / 5 \#$ & $3 / 4 \#$ & 3 & 3 & $3 / 6$ & 5 & 3 & 3 & $3 / 5$ & 3 & $\# 2 / 3$ & $3 / 4$ & $3 / 3 \#$ & 3 \\
\hline
\end{tabular}

Azul - Marcadores que segregam com a DM

Verde - Marcadores que não segregam com a DM

Amarelo - Marcadores não informativos

? - Não genotipado

\# - Pais diferentes

A região delimitada para o mapeamento da DM está realçada em negrito 
- Busca de microrrearranjos no cromossomo X por array-CGH e MLPA

Investigamos no probando a presença de desequilíbrios genômicos submicroscópicos no cromossomo $\mathrm{X}$ pela técnica de array-CGH, utilizando a plataforma Cytosure ${ }^{\mathrm{TM}}$, Chromosome X HD microarray 2x105K. Detectamos ganho de cópia de um segmento de aproximadamente 300 kb em Xq28 (ChrX:153,578,110153,880,794; $\mathrm{Hg} 19)$, na região candidata que delimitamos na análise de microssatélites (Figura 14). Esse segmento contém 18 genes, dos quais dois já foram associados a deficiência mental: FLNA (filamin A, alpha) e GDI1 (GDP dissociation inhibitor 1); além desses, o gene RPL10 (ribosomal protein L10) já foi associado a autismo (Klauck et al., 2006; Chiocchetti et al., 2011) e o gene ATP6AP1 (ATPase, H+ transporting, lysosomal accessory protein 1) é altamente expresso no cérebro. 
B
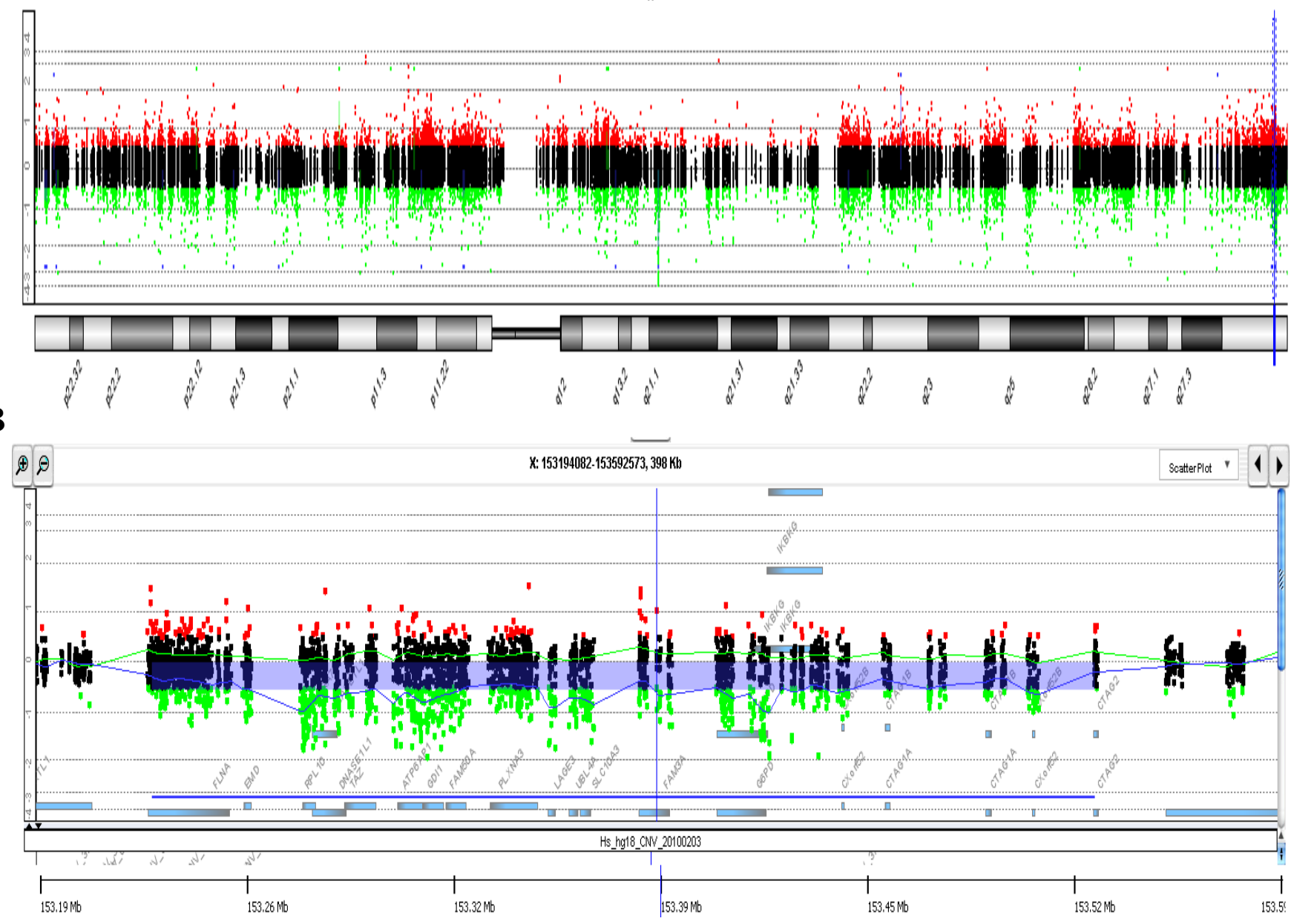

Figura 14: Microduplicação de aproximadamente $300 \mathrm{~Kb}$ em Xq28. (A) Perfil do cromossomo X (Cytosure ${ }^{\mathrm{TM}}$, Chromosome X HD microarray 2x105K), evidenciando a duplicação em Xq28. (B) Ampliação da região duplicada em Xq28. A barra azul na imagem B mostra a extensão do segmento duplicado, que contém 18 genes, dos quais dois já foram associados a deficiência mental.

Vandewalle et al. (2009) relataram um ganho complexo de número de cópias num segmento em Xq28, em indivíduos do sexo masculino com deficiência mental familial e em um menino, caso isolado de deficiência mental. As mulheres portadoras eram clinicamente normais. Os segmentos alterados iniciavam-se exatamente na mesma posição, coincidindo com o inicio da LCR K1 (Low Copy Repeat K1) e terminavam numa posição distal à LCR-L2. O tamanho do segmento alterado era de $317 \mathrm{~Kb}$ em duas famílias e no caso isolado, e de $324 \mathrm{~Kb}$ numa outra família, mas em todos os casos 
incluía 18 genes, os mesmos contidos na alteração aqui descrita. Entretanto o número de cópias não estava igualmente aumentado na extensão do segmento alterado, os genes podendo estar duplicados, triplicados e até quintuplicados, como demonstrado pela análise quantitativa por qPCR e pela análise dos níveis de expressão de mRNA. O gene GDIl foi considerado por Vandewalle et al. (2009) como o principal responsável pelo quadro clínico dos pacientes, já que a gravidade do fenótipo mostrou correlação com o número de cópias desse gene presentes nos afetados. O gene estava duplicado no caso isolado, que apresentava deficiência mental moderada não sindrômica; estava triplicado em duas famílias, em que os homens, com deficiência mental leve-moderada e sinais físicos considerados inconsistentes, tinham alargamento ventricular; os irmãos afetados de outra família tinham uma pentaduplicação e apresentavam deficiência mental moderada, microcefalia e malformação de Dandy-Walker, com hipoplasia de cerebelo e agenesia de corpo caloso. Os autores, porém, não descartaram a possibilidade de outros genes com número alterado de cópias estarem contribuindo para o quadro clínico, especialmente aqueles com alta expressão no cérebro, como ATP6AP1 e RPL10. Fusco et al. (2010) discordaram de Vandewalle et al. (2009), quando concluíram que o gene GDI1 seria o maior responsável pelo fenótipo manifestado pelos pacientes, e consideraram que o gene IKBKG (inhibitor of kappa light polypeptide gene enhancer in B-cells, kinase gamma), também com número de cópias alterado, poderia desempenhar papel importante na deficiência mental. Froyen et al. (2010) rebateram as críticas, ressaltando que em seu trabalho se referiram a homem normal portador de duplicação que incluía o gene $I K B K G$.

Para investigar se a alteração que detectamos no indivíduo IV-1 (Figura 13) segrega com a deficiência mental na família, realizamos experimentos de $M L P A$ conforme descrito em Métodos (III.2.1). Duas das sondas do kit utilizado hibridam no 
gene GDIl, que está mapeado no segmento alterado, uma sonda no exon 1 e outra no exon 7. Os resultados de MLPA (Figura 15) mostraram que o gene GDII está presente em pelo menos duas cópias em todos os indivíduos afetados estudados (III-1, 2, 5, 6 e 8 e IV-1). As mulheres (I-1; II-1, 3 e 6 e III-9), que são mães de afetados, todas clinicamente normais, também são portadoras da alteração. O menino III-4, fenotipicamente normal, não apresenta a alteração, nem III-7, uma menina também normal, com padrão de inativação do cromossomo X 59:41, portanto, dentro do esperado considerando a inativação casual do cromossomo $X(P=0.64)$. A mulher III-11é portadora da alteração de número de cópia de GDI1, mas não III-3 e III-10. Essas mulheres, sendo homozigóticas quanto à repetição CAG do gene $A R$ (Tabela IV), não permitiram que o padrão de inativação do X fosse determinado. Mas, fica claro que, na família, as portadoras da alteração apresentam desvios no padrão de inativação (Tabela IV) presentes em apenas cerca de $4 \%$ e $12 \%$ das mulheres adultas da população, de acordo com os dados de Amos-Landgraf et al. (2006). Esses resultados concordam com aqueles observados por Vandewalle et al. (2009), que relataram desvios de 70:30 a 100:0 nas portadoras da alteração de número de cópia desse segmento em Xq28; o tamanho dos desvios parecia correlacionar-se com o número de cópias do gene GDII. 
A

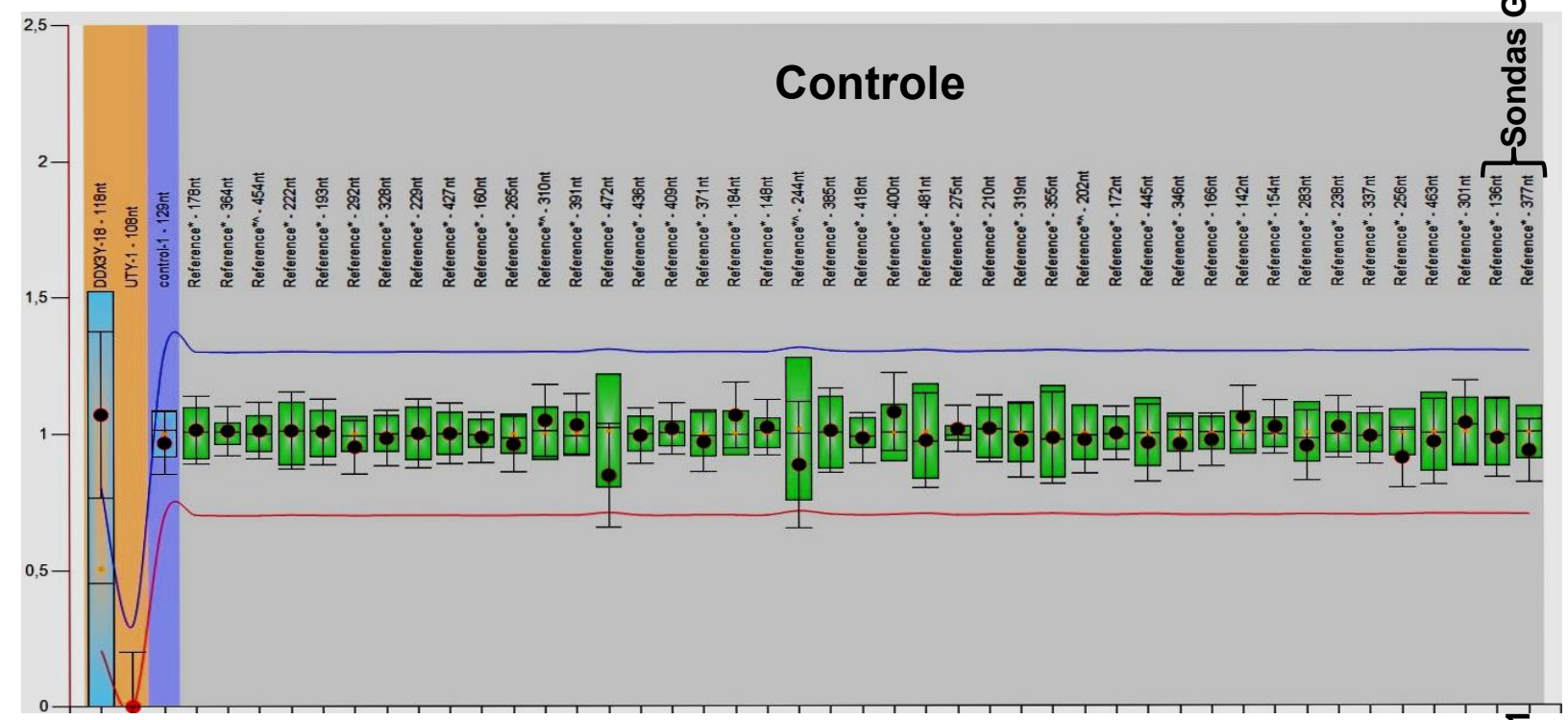

B

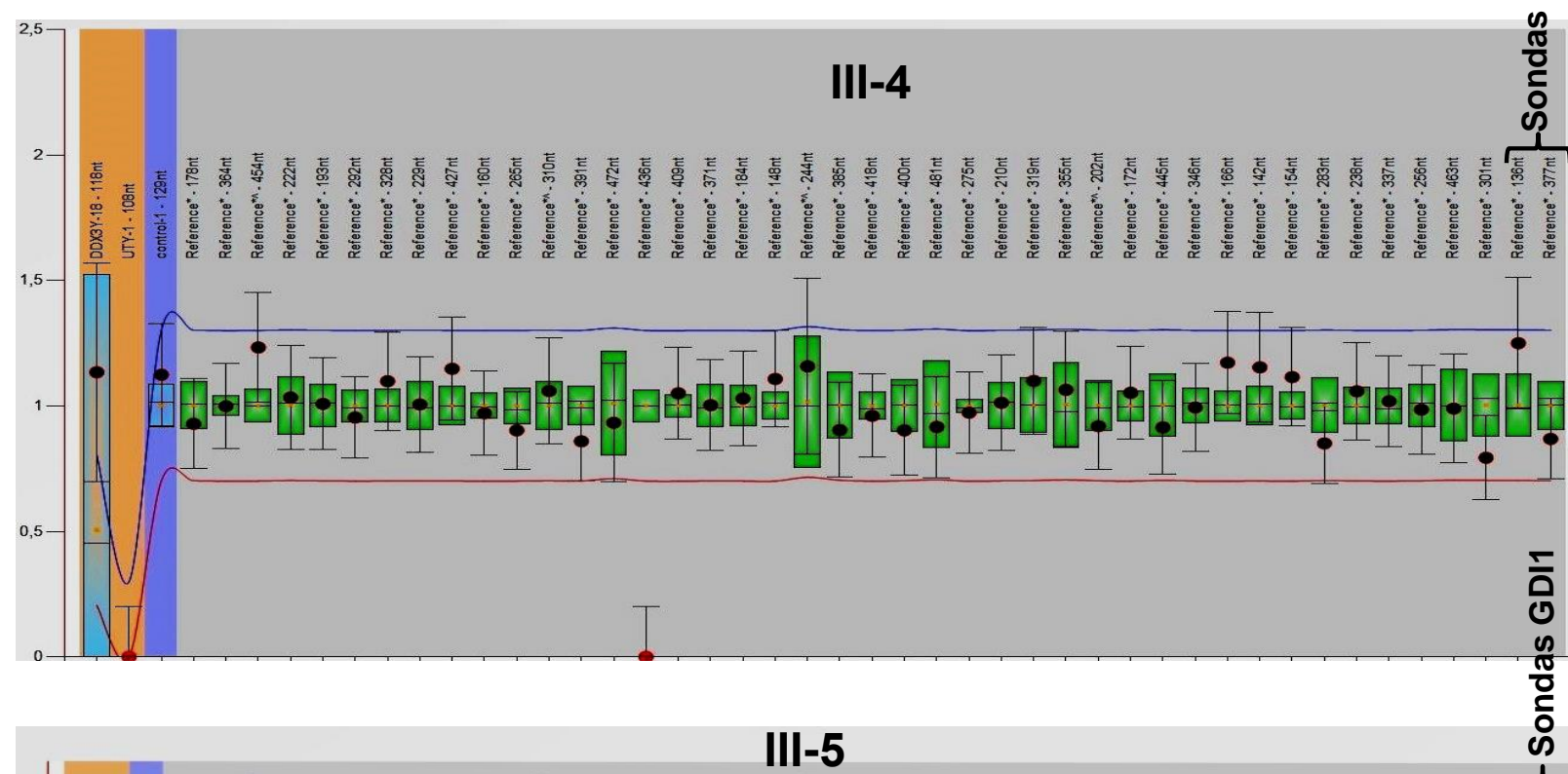

C

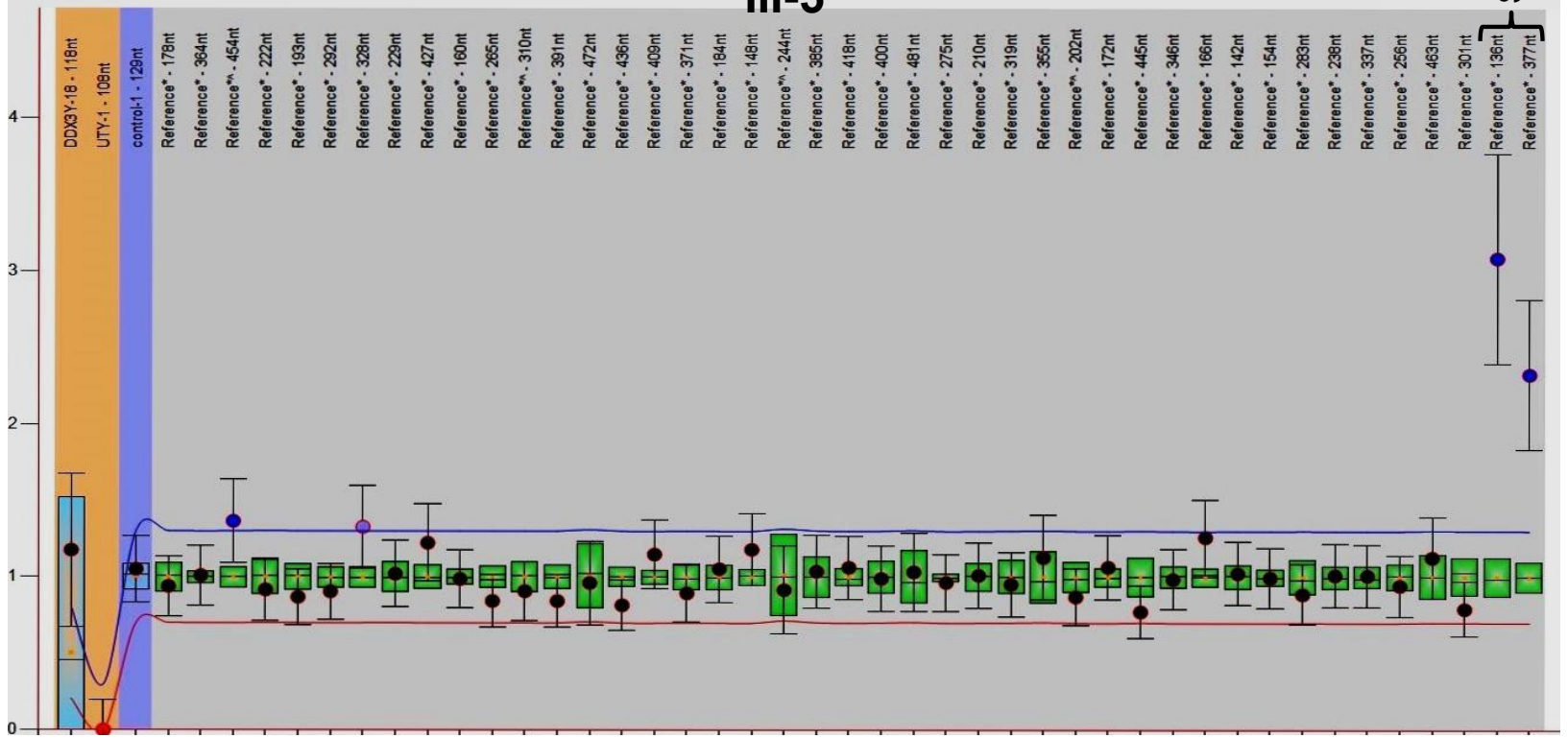


GDP dissociation inhibitor 1 (GDI1) é um regulador central de membros da família Rab GTPase. Recicla proteínas Rab da membrana e sequestra as proteínas Rab presentes no citosol na sua forma inativa ligada a GDP. O balanço entre a forma da proteína Rab ligada à membrana e a reserva citosólica do complexo Rab-GDI1 é essencial para o transporte vesicular e liberação de neurotransmissores (DerMardirossian e Bokoch, 2005).

D'Adamo et al. (1998) identificaram mutações no gene GDIl em indivíduos afetados da família MRX41, previamente descrita por Hamel et al. (1996) e na família MRX48 descrita por des Portes et al. (1997). Bienvenu et al. (1998), fizeram um screening de mutações na região codificadora do gene GDIl em 164 pacientes e identificaram uma nova mutação missense no exon 11 em uma família com deficiência mental não sindrômica. Todos os homens afetados apresentavam deficiência mental moderada a grave.

Os pacientes da Família 4 aqui descrita apresentam deficiência mental e microcefalia associadas a malformação de Dandy-Walker e alteração da substância branca periventricular. No estudo de Vandewalle et al. (2009), apenas pacientes com quatro cópias extras do gene GDII apresentaram malformação de Dandy-Walker. Nossa análise, utilizando a-CGH e MLPA, não permite quantificar precisamente o número de cópias do segmento alterado. A análise do número de cópias dos genes candidatos necessita ser realizada nos afetados dessa família, por PCR quantitativo (qPCR). 


\section{IV.2. Irmandades com dois ou mais indivíduos do sexo masculino com deficiência mental}

\section{- Pacientes}

Os pacientes com deficiência mental incluídos no estudo pertenciam a irmandades com pelo menos dois afetados do sexo masculino. Foram triadas 24 irmandades no Serviço de Aconselhamento Genético do Departamento de Genética e Biologia Evolutiva, do Instituto de Biociências da Universidade de São Paulo, para onde foram encaminhadas para diagnóstico e aconselhamento genético para a família. Os afetados possuíam deficiência mental moderada a grave, avaliada com base em suas limitações cognitivas e comportamentais. Para o estudo, foram selecionados os pacientes cujos sinais clínicos não eram característicos de síndrome conhecida e que tiveram resultados normais em exame cromossômico, realizado após bandamento G, e em teste molecular para a síndrome do cromossomo X frágil.

\section{- Padrão de inativação do cromossomo X nas genitoras dos afetados}

Foram analisadas, quanto ao padrão de inativação do cromossomo $\mathrm{X}, 24$ mulheres mães de pelo menos dois pacientes do sexo masculino afetados por deficiência mental (Tabela VI). Utilizamos como critério de seleção de candidatas a serem portadoras de mutação no cromossomo $\mathrm{X}$ o desvio de inativação $\geq 95 \%[\mathrm{P}<0.05$, considerando a distribuição do padrão de inativação do X obtida por Amos-Landgraf $e t$ al. (2006), ao estudarem 415 mulheres adultas da população geral]. Todas as mulheres eram heterozigóticas quanto à repetição $\mathrm{CAG}$ do gene $A R$ e, portanto, foram informativas (Tabela VI). Três dessas mulheres apresentaram desvio total de inativação 
(padrão 100:0) e uma, desvio praticamente completo (padrão 3:97). A frequência de mulheres com esses desvios extremos de inativação na amostra (16,7\%; IC 95\% 0,0473 - 0,3741) é claramente maior $(\mathrm{P}=0.0018$; teste exato de Fisher $)$ do que aquela encontrada por Amos-Landgraf et al. (2006) (0,017; IC 95\% = 0,007 - 0,035).

Considerando (a) a raridade dos desvios extremos da inativação do cromossomo $\mathrm{X}$ na população geral de mulheres e (b) que cerca de um terço das mulheres portadoras obrigatórias de mutações do cromossomo $\mathrm{X}$ que causam deficiência mental com herança ligada ao X mostram desvios de inativação extremos - $\geq 90: 10$ (Plenge et al., 2002), as quatro mulheres mães de mais de um menino afetado por deficiência mental podem ser consideradas como muito provavelmente portadoras de mutações que causam a deficiência mental em seus filhos. Na verdade, com base nos dados de seu estudo da inativação do cromossomo $\mathrm{X}$ em mulheres da população geral, Amos-Landgraf et al. (2006), estimam que para uma recém nascida numa família em que segrega uma doença de herança ligada ao X, sabidamente associada a desvios significativos da inativação do $X$, um desvio $\geq 90: 10$ lhe confere uma chance de aproximadamente 100:1 de ser portadora da mutação; no caso de uma mulher qualquer da população com desvio de inativação $\geq 90: 10$, suas chances são iguais de ser ou não portadora de mutação patogênica no cromossomo X. 
Tabela VI: Padrão de inativação do cromossomo X em 24 mulheres mães de dois ou mais pacientes do sexo masculino com deficiência mental (DM).

\begin{tabular}{|c|c|c|c|}
\hline Mulher & $\begin{array}{c}\text { Idade ao exame } \\
\text { (anos) }\end{array}$ & $\begin{array}{l}\text { Razão de inativação* } \\
\text { (alelos maior:menor) }\end{array}$ & $\begin{array}{c}\text { No. de filhos } \\
\text { com DM }\end{array}$ \\
\hline 1 & 50,08 & $38: 62$ & 2 \\
\hline 2 & 42 & $53: 47$ & 2 \\
\hline 3 & 41 & $52: 48$ & 2 \\
\hline 4 & 32,83 & $57: 43$ & 2 \\
\hline 5 & 35,75 & $65: 35$ & 2 \\
\hline 6 & 42,42 & $70: 30$ & 2 \\
\hline 7 & 41 & $58: 42$ & 2 \\
\hline 8 & 34,25 & $27: 73$ & 2 \\
\hline 9 & 38 & $77: 23$ & 2 \\
\hline 10 & 35,83 & $42: 58$ & 2 \\
\hline 11 & 42,75 & $74: 26$ & 2 \\
\hline 12 & 31,67 & $50: 50$ & 2 \\
\hline 13 & 40,33 & $64: 36$ & 2 \\
\hline 14 & 43,92 & $12: 88$ & 2 \\
\hline 15 & 31,33 & $18: 82$ & 2 \\
\hline 16 & 46,83 & $24: 76$ & 2 \\
\hline 17 & 28,42 & $59: 41$ & 2 \\
\hline 18 & 44,75 & $12: 88$ & 2 \\
\hline 19 & 36 & 100:0 & 3 \\
\hline 20 & 46,08 & 03:97 & 2 \\
\hline 21 & 31,33 & $38: 62$ & 2 \\
\hline 22 & 39,2 & $53: 47$ & 2 \\
\hline 23 & 35,42 & 100:0 & 2 \\
\hline 24 & - & 100:0 & $\begin{array}{c}3 \text { (um par de } \\
\text { gêmeos) }\end{array}$ \\
\hline
\end{tabular}

*(phd1/phu1)/(phd1/phu1)+(phd2/phu2), em que phd1 = alelo menor do gene AR, após digestão com HpaII, phu 1 = alelo menor não digerido, phd $2=$ alelo maior após digestão com $H p a I I$ e phu 2 = maior alelo não digerido. 


\section{- Busca de microrrearranjos no cromossomo $X$}

Investigamos duplicações e deleções submicroscópicas do cromossomo X, por array $\mathrm{CGH}$, utilizando a plataforma Cytosure $^{\mathrm{TM}}$, Chromosome $\mathrm{X}$ HD microarray 2x105K, nos pacientes cujas mães apresentaram desvios extremos de inativação do cromossomo X (19, 20, 23 e 24 - Tabela VI). Não encontramos alteração patogênica.

Considerando que a frequência de microduplicações ou microdeleções do cromossomo $\mathrm{X}$ relacionadas a deficiência mental familial com herança ligada ao X é de cerca de $10 \%$ (Whibley et al., 2010), esse resultado nesse pequeno grupo de pacientes está dentro do esperado. Em um estudo do laboratório (dados não publicados), em que 133 mulheres mães de um menino com deficiência mental foram analisadas quanto ao padrão de inativação do cromossomo $X$, não foram detectadas microduplicações ou microdeleções patogênicas no cromossomo $X$, nos 15 meninos cujas mães tinham desvios completos da inativação (padrão 100:0). Somando-se aos quatro casos de mães de afetados por deficiência mental, com desvio completo de inativação do cromossomo $\mathrm{X}$, aqui estudados, são 19 mulheres com desvios completos da inativação, em que a deficiência mental de seus filhos não tem como causa microduplicações ou microdeleções do cromossomo X. Assim, a inativação do X completamente desviada nas mães de afetados não parece aumentar a chance de que a deficiência mental seja causada por variações patogênicas do número de cópias de segmentos do cromossomo $\mathrm{X}$.

Ganhos e perdas de segmentos do cromossomo $\mathrm{X}$ detectados ao exame cromossômico após bandamento $\mathrm{G}$ estão associados a desvios extremos do padrão de inativação do $\mathrm{X}$ nas portadoras, com o cromossomo alterado sempre inativo; admite-se que esse padrão de inativação seja resultado da seleção contra as células que têm o 
cromossomo X alterado ativo. Entretanto, as microduplicações e microdeleções do cromossomo X não parecem aumentar a probabilidade de a portadora apresentar desvios extremos no padrão de inativação do cromossomo X. Num estudo de 45 mulheres com desvios $\geq 85 \%$, e 45 controles sem esses desvios, Jobanputra et al. (2012) não observaram diferenças significativas quanto a presença de variações no número de cópias de segmentos do cromossomo $\mathrm{X} \geq 100 \mathrm{~kb}$ nem quanto a segmentos alterados contendo genes. 


\section{SUMÁRIO E CONCLUSÕES}




\section{SUMÁRIO E CONCLUSÕES}

Este trabalho teve o objetivo de identificar genes candidatos a deficiência mental de herança ligada ao cromossomo X. Estudamos quatro famílias, em que a deficiência mental segregava num padrão típico de herança ligada ao X e 24 irmandades com pelo menos dois indivíduos do sexo masculino apresentando deficiência mental. A síndrome do cromossomo $\mathrm{X}$ frágil e alterações cromossômicas detectáveis na análise após bandamento $\mathrm{G}$ foram afastadas como causa da deficiência mental. Iniciamos o estudo determinando o padrão de inativação do cromossomo X nas mães dos afetados, uma vez que padrões de inativação do cromossomo $\mathrm{X}$ extremamente desviados são frequentes em portadoras de mutações no cromossomo $X$, que causam deficiência mental em homens. Em seguida, buscamos desequilíbrios submicroscópicos do cromossomo $\mathrm{X}$, por meio de hibridação genômica comparativa baseada em array (a-CGH), nos probandos dos casos familiais e das irmandades com dois ou mais afetados cujas mães apresentaram desvios extremos de inativação do cromossomo X. Nos casos familiais, delimitamos região candidata a conter o gene alterado, genotipando marcadores moleculares do tipo microssatélites e excluindo os segmentos que não segregavam com a deficiência mental; alguns genes que já haviam sido associados a deficiência mental e que estavam localizados nos segmentos delimitados foram sequenciados; os exomas de três propósitos foram sequenciados.

Na Família 1 os afetados, em duas gerações, apresentavam deficiência mental grave-profunda associada a microcefalia, baixa estatura, fácies peculiar e puberdade precoce. As portadoras obrigatórias apresentaram desvio total de inativação do cromossomo X. Em estudo anterior, tinha sido detectada, nessa família, uma microdeleção no cromossomo X que, inicialmente considerada como causal, pôde ser 
descartada pela sua ocorrência populacional. Utilizando marcadores do tipo microssatélites, delimitamos uma região candidata de aproximadamente $29 \mathrm{Mb}$ entre DXS1068 (Xp11.4 - 38,908,227-38,908,332) e DXS1216 (Xq13.1 - 68,264,35368,464,720). Dentre os 26 genes já relacionados a deficiência mental contidos nesse segmento, sequenciamos 12 e não encontramos alteração: ZNF81 (zinc finger protein 81), PQBP1 (polyglutamine binding protein 1), ATP6AP2 (ATPase, $\mathrm{H}+$ transporting, lysosomal accessory protein 2), OTC (ornithine carbamoyltransferase), MAOA (monoamine oxidase A), KDM5C (lysine (K)-specific demethylase 5C), FGD1 (FYVE, RhoGEF and PH domain containing 1), HSD17B10 (hydroxysteroid (17-beta) dehydrogenase 10), SYN1 (synapsin I), SHROOM4 (shroom family member 4), TSPAN7 (tetraspanin 7) e OPHN1 (oligophrenin 1). Posteriormente, o sequenciamento do exoma do probando revelou duas mutações missense, com alta chance de serem patogênicas, nos genes TIMP1 (TIMP metallopeptidase inhibitor 1) e HUWE1 (HECT, UBA and WWE domain containing 1, E3 ubiquitin protein ligase), mapeados no segmento que segregava com a doença na família. As patologias já associadas com níveis alterados da proteína TIMP1 tornaram pouco provável que a mutação tivesse associação causal com a deficiência mental na família. O gene $H U W E 1$, por sua vez, codifica um membro da família de ligases de ubiquitina HECT E3 e já foi associado a deficiência mental. A mutação c. $12378 \mathrm{C}>\mathrm{G}$ resulta na substituição do aminoácido cisteína por triptofano (C4126W), no domínio HECT, em posição evolutivamente conservada e segrega com a deficiência mental na família. Muito provavelmente essa mutação é a causa da deficiência mental na Família 1.

Os afetados da Família 2, dois primos em primeiro grau e um tio materno, apresentavam deficiência mental aparentemente moderada associada a dismorfismos. Suas mães apresentaram desvio completo da inativação do cromossomo X. No 
propósito, não foram detectadas microdeleções ou microduplicações do cromossomo X. A genotipagem de marcadores do tipo microssatélites permitiu delimitar uma região de aproximadamente $70 \mathrm{Mb}$ entre os marcadores DXS993 $(41,147,683-41,147,988)$ e DXS1059 $(111,325,975-111,326,164)$, como candidata a conter a mutação causadora da deficiência mental. Nesse segmento estão mapeados 44 genes já associados a deficiência mental. Sequenciamos inicialmente os genes PQBP1, HSD17B10, KDM5C, SYN1 e OPHN1 e não encontramos alteração. O sequenciamento do exoma do propósito revelou, no segmento candidato, mutações missense, com alta probabilidade de serem patogênicas, nos genes TAF1 (TAF1 RNA polymerase II, tata box-binding proteinassociated factor) e SHROOM4 (shroom family member 4). A mutação c.4406A>T no gene TAF1 leva à substituição do aminoácido histidina por leucina (H1469L), numa sequência extremamente conservada entre os mamíferos. Entretanto, a única doença já associada a mutação no gene TAF1 é a distonia de torsão-parkinsonismo, de manifestação tardia, com o aparecimento dos primeiros sinais na terceira década de vida, o que torna pouco provável que a mutação nesse gene seja responsável pela deficiência mental na família. A mutação missense c.1413C>A no gene SHROOM4 resulta na substituição do aminoácido prolina por treonina (P463T). A prolina substituída é altamente conservada entre os mamíferos. Alterações no gene SHROOM4 (mutação familial missense e quebra do gene em dois casos de translocação $\mathrm{X}$;autossomo) já foram relacionadas anteriormente a deficiência mental. A mutação que detectamos, que segrega com a deficiência mental, aparece, assim, como causa mais provável da deficiência mental na Família 2.

Na Família 3, dois irmãos e um primo materno em primeiro grau apresentavam deficiência mental grave associada a dismorfismos; um dos meninos tinha tetralogia de Fallot. As mães dos afetados apresentaram desvio total de inativação do cromossomo X. 
No propósito não foram detectadas microduplicações ou microdeleções no cromossomo X. Usando marcadores do tipo microssatélite, foi possível delimitar uma região candidata para conter a mutação responsável pela deficiência mental, de aproximadamente $40 \mathrm{Mb}$, entre os marcadores DXS8080 (44,243,430-44,243,620) e DXS1196 (86,688,618-86,688,830). Nesse segmento estão mapeados 32 genes já associados a deficiência mental. Dentre esses, sequenciamos os genes $S Y N 1, P Q B P 1$, SHROOM4, KDM5C, HSD17B10, FGD1 e OPHN1 e não encontramos alteração patogênica. A análise do exoma do propósito revelou, no segmento candidato, uma mutação missense com alta probabilidade de ser patogênica no gene KIAA2022. A mutação - c.262G>A resulta na substituição do ácido glutâmico, altamente conservado em mamíferos, por lisina (E88K) e segrega com a deficiência mental na família. O gene KIAA2022 já foi relacionado a deficiência mental, tendo sido rompido por uma das quebras de uma inversão pericêntrica do cromossomo $\mathrm{X}$ em afetados de uma família. É provável, assim, que a mutação que detectamos no gene KIAA2022 seja responsável pela deficiência mental na Família 3.

Na Família 4, o propósito, seu irmão, três primos em primeiro grau e um primo em segundo grau apresentavam deficiência mental associada a microcefalia. No propósito e em seu irmão foi documentada malformação de Dandy-Walker. As mães dos afetados apresentaram desvios significativos da inativação do cromossomo $\mathrm{X}$ (80:20 e 90:10). Uma duplicação de segmento de aproximadamente 300 kb em Xq28 (ChrX:153,578,110-153,880,794 - Hg19) foi detectada nos afetados e em suas mães. Esse segmento contém 18 genes, dos quais dois, FLNA (filamin A, alpha) e GDI1 (GDP dissociation inhibitor 1) já foram associados a deficiência mental, RPL10 (ribosomal protein L10) foi associado a autismo e ATP6AP1 (ATPase, H+ transporting, lysosomal accessory protein 1) é altamente expresso no cérebro. Ganhos de cópias de segmentos 
semelhantes foram descritos anteriormente associados a deficiência mental em três famílias e em um caso isolado, alguns afetados apresentando malformação de DandyWalker, indicando ser esta a causa da deficiência mental na Família 4.

No estudo das 24 irmandades com pelo menos dois indivíduos do sexo masculino com deficiência mental, determinamos o padrão de inativação do cromossomo X nas mães dos afetados. Quatro mulheres $(16,7 \%)$ apresentaram desvios extremos de inativação do cromossomo X (padrão 100:0), frequência significativamente maior do que aquela registrada na literatura para desvios de inativação $\geq 95 \%$ em mulheres da população geral (aproximadamente $2 \%$ ). Considerando ainda que cerca de $30 \%$ das portadoras de mutações que causam deficiência mental de herança ligada ao X têm desvios significativos de inativação, admitimos que as mães de pelo menos dois afetados, apresentando tais desvios eram provavelmente portadoras de mutações responsáveis pela deficiência mental em seus filhos. Investigamos a presença de microduplicações e microdeleções do cromossomo $\mathrm{X}$ nos probandos dessas quatro irmandades e não encontramos alterações. 
ABSTRACT 


\section{ABSTRACT}

This study aimed at identifying candidate genes for X-linked intellectual disability (ID). Four families in which ID of unknown cause segregated as an X-linked trait, and 24 sibships with at least two affected males were investigated. The pattern of $\mathrm{X}$-inactivation was determined in the mothers of affected males, taking into account that extremely skewing of $\mathrm{X}$-inactivation is frequently found in women carrying mutations causative of X-linked intellectual disability (XLID). In the XLID families, ID was mapped by the genotyping of microsatellite markers localized throughout the $\mathrm{X}$ chromosome. Cryptic X-chromosome imbalances were investigated by array-based comparative genomic hybridization (a-CGH). Positional candidate genes that had been associated with ID were directly sequenced in the search for causative mutations. In three XLID families, the propositus had their exome sequenced.

In three XLID families missense mutations that led to substitutions of conservative amino acid residues were found that segregated with ID, and were probably causative of the clinical phenotypes: c.12378C $>\mathrm{G}$ in $H U W E 1$ (HECT, UBA and WWE domain containing 1, E3 ubiquitin protein ligase) gene; c.1413C>A in the SHROOM4 (shroom family member 4) gene; c.262G>A in the KIAA2022 gene. Heterozygotes for these mutations had completely skewed X-inactivation (100:0 inactivation ratio). Point mutations or disruption of these genes by rearrangement breakpoints have been previously described in a few patients with ID.

In one family in which XLID was associated with microcephaly and DandyWalker malformation, a duplication of approximately $300 \mathrm{~kb}$ at Xq28 (ChrX:153,578,110-153,880,794 - Hg19) was found segregating with the disease. Heterozygotes for this duplication had skewed X-inactivation (80:20 and 90:10 
inactivation ratios). Similar duplications have been described in three European families and one sporadic case, Dandy-Walker malformation being documented in some patients.

In the study of the 24 sibships with at least two males presenting with ID, the maternal pattern of X-inactivation was determined. Four women (16.7\%) showed completely skewing of $\mathrm{X}$-inactivation (100:0 inactivation ratio), a frequency significantly higher than the reported frequency of skewing $\geq 95 \%$ in women from the general population (about 2\%). Considering this finding and that extremely skewed Xinactivation have been reported in about $30 \%$ of carriers of mutations causing XLID, it was assumed that the four mothers of males presenting with ID were most probably carriers of the mutations causative of ID in their sons. Chromosome $\mathrm{X}$ microimbalances were not found in the propositus, in these four sibships. 


\section{REFERÊNCIAS BIBLIOGRÁFICAS}




\section{REFERÊNCIAS BIBLIOGRÁFICAS}

Allen RC, Zoghbi HY, Moseley AB, Rosenblatt HM, Belmont JW - Methylation of HpaII and HhaI sites near the polymorphic CAG repeat in the human androgenreceptor gene correlates with X chromosome inactivation. Am J Hum Genet 51: 1229-39, 1992.

American Psychiatric Association - Diagnostic and statistical manual of mental disorders DSM-IV (American Psychiatric Association), Washington, D.C., 1994.

Amos-Landgraf JM, Cottle A, Plenge RM, Friez M, Schwartz CE, Longshore J, Willard HF - X chromosome-inactivation patterns of 1,005 phenotypically unaffected females. Am J Hum Genet 79:493-99, 2006.

Anderson CL, Brown CJ - Variability of X chromosome inactivation: effect of levels of TIMP1 RNA and role of DNA methylation. Hum Genet 110:271-78, 2002.

Biancalana V, Beldjord C, Taillandier A, Szpiro-Tapia S, Cusin V, Gerson F, Philippe C, Mandel JL - Five years of molecular diagnosis of Fragile X syndrome (19972001): a collaborative study reporting 95\% of the activity in France. Am J Med Genet 129A:218-24, 2004.

Bienvenu T, des Portes V, Saint Martin A, McDonell N, Billuart P, Carrié A, Vinet MC, Couvert P, Toniolo D, Ropers HH, Moraine C, van Bokhoven H, Fryns JP, Kahn A, Beldjord C, Chelly J - Non-specific X-linked semidominant mental retardation by mutations in a Rab GDP-dissociation inhibitor. Hum Mol Genet 7:1311-15, 1998.

Bittel DC, Theodoro MF, Kibiryeva N, Fischer W, Talebizadeh Z, Butler MG Comparison of X-chromosome inactivation patterns in multiple tissues from human females. J Med Genet 45:309-13, 2008.

Bochtler M, Ditzel L, Groll M, Hartmann C, Huber R - The proteasome. Ann Rev Biophys Biomol Struct 28:295-317, 1999.

Cantagrel V, Lossi A-M, Boulanger S, Depetris D, Mattei M-G, Gecz J, Schwartz CE, Van Maldergem L, Villard L - Disruption of a new X linked gene highly expressed in brain in a family with two mentally retarded males. J Med Genet 41:736-42, 2004. 
Cantagrel V, Haddad MR, Ciofi P, Andrieu D, Lossi AM, Maldergem Lv, Roux JC, Villard L - Spatiotemporal expression in mouse brain of Kiaa2022, a gene disrupted in two patients with severe mental retardation. Gene Expr Patterns 9:423-29, 2009.

Chiocchetti A, Pakalapati G, Duketis E, Wiemann S, Poustka A, Poustka F, Klauck SM - Mutation and expression analyses of the ribosomal protein gene RPL10 in an extended German sample of patients with autism spectrum disorder. Am J Med Genet 155A:1472-75, 2011.

Chiurazzi P, Oostra BA - Genetics of mental retardation. Curr Opin Pediatr 12:529$35,2000$.

Conaway RC, Brower CS, Conaway JW - Emerging roles of ubiquitin in transcription regulation. Science 296:1254-58, 2002.

Coqueti KN - O cromossomo X e a deficiência mental no sexo masculino. Dissertação de Mestrado. Instituto de Biociências, USP, 2011. 56pp.

Crawford DC, Acuna JM, Sherman SL - FMR1 and the fragile X syndrome: human genome epidemiology review. Genet Med 3:359-71, 2001.

D'Adamo P, Menegon A, Lo Nigro C, Grasso M, Gulisano M, Tamanini F, Bienvenu T, Gedeon AK, Oostra B, Wu SK, Tandon A, Valtorta F, Balch WE, Chelly J, Toniolo D - Mutations in GDI1 are responsible for X-linked non-specific mental retardation. Nat Genet 19:134-39, 1998.

de Brouwer AP, Yntema HG, Kleefstra T, Lugtenberg D, Oudakker AR, de Vries BB, van Bokhoven H, Van Esch H, Frints SG, Froyen G, Fryns JP, Raynaud M, Moizard MP, Ronce N, Bensalem A, Moraine C, Poirier K, Castelnau L, Saillour Y, Bienvenu T, Beldjord C, des Portes V, Chelly J, Turner G, Fullston T, Gecz J, Kuss AW, Tzschach A, Jensen LR, Lenzner S, Kalscheuer VM, Ropers HH, Hamel BC - Mutation frequencies of X-linked mental retardation genes in families from the EuroMRX consortium. Hum Mutat 28:207-08, 2007.

DerMardirossian C, Bokoch GM - GDIs: central regulatory molecules in Rho GTPase activation. Trends Cell Biol 15:356-63, 2005. 
des Portes V, Soufir N, Carrié A, Billuart P, Bienvenu T, Vinet MC, Beldjord C, Ponsot G, Kahn A, Boué J, Chelly J - Gene for nonspecific X-linked mental retardation (MRX 47) is located in Xq22.3-q24. Am J Med Genet 72:324-28, 1997.

Devriendt K, Vermeesch JR - Chromosomal phenotypes and submicroscopic abnormalities. Hum Genomics 2:126-33, 2004.

Dover J, Schneider J, Boateng MA, Wood A, Dean K, Johnston M, Shilatifard A Methylation of histone $\mathrm{H} 3$ by COMPASS requires ubiquitination of histone $\mathrm{H} 2 \mathrm{~B}$ by RAD6. J Biol Chem 277:28368-71, 2002.

Fishburn J, Turner G, Daniel A, Brookwell R - The diagnosis and frequency of X-linked conditions in a cohort of moderately retarded males with affected brothers. Am J Med Genet 4:713-24, 1983.

Froyen, G - Response to Fusco et al. (Letter) Am J Hum Genet 86:652-53, 2010.

Froyen G, Corbett M, Vandewalle J, Jarvela I, Lawrence O, Meldrum C, Bauters M, Govaerts K, Vandeleur L, Van Esch H, Chelly J, Sanlaville D, van Bokhoven H, Ropers HH, Laumonnier F, Ranieri E, Schwartz CE, Abidi F, Tarpey PS, Futreal PA, Whibley A, Raymond FL, Stratton MR, Fryns JP, Scott R, Peippo M, Sipponen M, Partington M, Mowat D, Field M, Hackett A, Marynen P, Turner G, Gécz J - Submicroscopic duplications of the hydroxysteroid dehydrogenase HSD17B10 and the E3 ubiquitin ligase HUWE1 are associated with mental retardation. Am J Hum Genet 82:432-43, 2008.

Froyen G, Belet S, Martinez F, Santos-Rebouças CB, Declercq M, Verbeeck J, Donckers L, Berland S, Mayo S, Rosello M, Pimentel MM, FintelmanRodrigues N, Hovland R, Rodrigues dos Santos S, Raymond FL, Bose T, Corbett MA, Sheffield L, van Ravenswaaij-Arts CM, Dijkhuizen T, Coutton C, Satre V, Siu V, Marynen P. Copy-number gains of HUWE1 due to replicationand recombination-based rearrangements. Am J Hum Genet 91:252-64, 2012.

Fusco F, D'Urso M, Miano MG, Ursini MV - The LCR at the IKBKG locus is prone to recombine. (Letter) Am J Hum Genet 86:650-52, 2010. 
Girirajan S, Rosenfeld JA, Cooper GM, Antonacci F, Siswara P, Itsara A, Vives L, Walsh T, McCarthy SE, Baker C, Mefford HC, Kidd JM, Browning SR, Browning BL, Dickel DE, Levy DL, Ballif BC, Platky K, Farber DM, Gowans GC, Wetherbee JJ, Asamoah A, Weaver DD, Mark PR, Dickerson J, Garg BP, Ellingwood SA, Smith R, Banks VC, Smith W, McDonald MT, Hoo JJ, French BN, Hudson C, Johnson JP, Ozmore JR, Moeschler JB, Surti U, Escobar LF, ElKhechen D, Gorski JL, Kussmann J, Salbert B, Lacassie Y, Biser A, McDonaldMcGinn DM, Zackai EH, Deardorff MA, Shaikh TH, Haan E, Friend KL, Fichera M, Romano C, Gécz J, DeLisi LE, Sebat J, King MC, Shaffer LG, Eichler EE - A recurrent 16p12.1 microdeletion supports a two-hit model for severe developmental delay. Nat Genet 42:203-10, 2010.

Graves JA, Gecz J, Hameister H - Evolution of the human X - a smart and sexy chromosome that controls speciation and development. Cytogenet Genome Res 99:141-45, 2002.

Haddad LA, Mingroni-Netto RC, Vianna-Morgante AM, Pena SD - A PCR-based test suitable for screening for fragile $\mathrm{X}$ syndrome among mentally retarded males. Hum Genet 97:808-12, 1996.

Hagens O, Dubos A, Abidi F, Barbi G, Van Zutven L, Hoeltzenbein M, Tommerup N, Moraine C, Fryns JP, Chelly J, van Bokhoven H, Gécz J, Dollfus H, Ropers HH, Schwartz CE, Stocco dos Santos RC, Kalscheuer V, Hanauer A - Disruptions of the novel KIAA1202 gene are associated with X-linked mental retardation. Hum Genet 118:578-90, 2006.

Hamel BC, Kremer H, Wesby-van Swaay E, van den Helm B, Smits AP, Oostra BA, Ropers HH, Mariman EC - A gene for nonspecific X-linked mental retardation (MRX41) is located in the distal segment of Xq28. Am J Med Genet 64:131-33, 1996.

Honda S, Hayashi S, Imoto I, Toyama J, Okazawa H, Nakagawa E, Goto Y, Inazawa J Copy-number variations on the $\mathrm{X}$ chromosome in Japanese patients with mental retardation detected by array-based comparative genomic hybridization analysis.

J Hum Genet 55:590-99, 2010. 
Huibregtse JM, Scheffner M, Beaudenon S, Howley PM - A family of proteins structurally and functionally related to the E6-AP ubiquitin-protein ligase. Proc Natl Acad Sci USA 92:5249, 1995.

Inlow JK, Restifo, LL - Molecular and comparative genetics of mental retardation. Genetics 166:835-81, 2004.

Jobanputra V, Levy B, Kinney A, Brown S, Shirazi M, Yu C, Kline J, Warburton D Copy number changes on the $\mathrm{X}$ chromosome in women with and without highly skewed X-chromosome inactivation. Cytogenet Genome Res 136:264-69, 2012.

Kalscheuer VM, Freude K, Musante L, Jensen LR, Yntema HG, Gécz J, Sefiani A, Hoffmann K, Moser B, Haas S, Gurok U, Haesler S, Aranda B, Nshedjan A, Tzschach A, Hartmann N, Roloff TC, Shoichet S, Hagens O, Tao J, Van Bokhoven H, Turner G, Chelly J, Moraine C, Fryns JP, Nuber U, Hoeltzenbein M, Scharff C, Scherthan H, Lenzner S, Hamel BC, Schweiger S, Ropers HH Mutations in the polyglutamine binding protein 1 gene cause $\mathrm{X}$-linked mental retardation. Nat Genet 35:313-15, 2003.

Kenney MC, Chwa M, Atilano SR, Tran A, Carballo M, Saghizadeh M, Vasiliou V, Adachi W, Brown DJ - Increased levels of catalase and cathepsin V/L2 but decreased TIMP-1 in keratoconus corneas: evidence that oxidative stress plays an role in this disorder. Invest Ophthal Vis Sci 46:823-32, 2005.

Kim HC, Huibregtse JM - Polyubiquitination by HECT E3s and the determinants of chain type specificity. Mol Cell Biol 29:3307-18, 2009.

Klauck SM, Felder B, Kolb-Kokocinski A, Schuster C, Chiocchetti A, Schupp I, Wellenreuther R, Schmötzer G, Poustka F, Breitenbach-Koller L, Poustka A Mutations in the ribosomal protein gene RPL10 suggest a novel modulating disease mechanism for autism. Mol Psychiatry 11:1073-84, 2006.

Lehrke R - A theory of X-linkage of major intellectual traits. Am J Mental Deficiency 78:611-19, 1972.

Lubs HA, Stevenson RE, Schwartz CE - Fragile X and X-linked intellectual disability: four decades of discovery. Am J Hum Genet 90:579-90, 2012. 
Lugtenberg D, Veltman JA, van Bokhoven H - High-resolution genomic microarrays for X-linked mental retardation. Genet Med 9:560-65, 2007.

Lugtenberg D, Zangrande-Vieira L, Kirchhoff M, Whibley AC, Oudakker AR, Kjaergaard S, Vianna-Morgante AM, Kleefstra T, Ruiter M, Jehee FS, Ullmann R, Schwartz CE, Stratton M, Raymond FL, Veltman JA, Vrijenhoek T, Pfundt R, Schuurs-Hoeijmakers JHM, Hehir-Kwa JY, Froyen G, Chelly J, Ropers HH, Moraine C, Gècz J, Knijnenburg J, Kant SG, Hamel BCJ, Rosenberg C, van Bokhoven H, de Brouwer AP - Recurrent deletion of ZNF630 at Xp11.23 is not associated with mental retardation. Am J Med Genet A 152:638-45, 2010.

Makino S, Kaji R, Ando S, Tomizawa M, Yasuno K, Goto S, Matsumoto S, Tabuena MD, Maranon E, Dantes M, Lee LV, Ogasawara K, Tooyama I, Akatsu H, Nishimura M, Tamiya G - Reduced neuron-specific expression of the TAF1 gene is associated with X-linked dystonia-parkinsonism. Am J Hum Genet 80: 393-406, 2007.

Mandel JL, Chelly J - Monogenic X-linked mental retardation: is it as frequent as currently estimated? The paradox of the ARX (Aristaless X) mutations. Eur J Hum Genet 12:689-93, 2004.

Muers MR, Sharpe JA, Garrick D, Sloane-Stanley J, Nolan PM, Hacker T, Wood WG, Higgs DR, Gibbons RJ - Defining the cause of skewed X-chromosome inactivation in X-linked mental retardation by use of a mouse model. Am J Hum Genet 80: 1138-49, 2007.

Nascimento RMP, Otto PA, de Brouwer APM, Vianna-Morgante AM - UBE2A, which encodes a ubiquitin-conjugating enzyme, is mutated in a novel X-linked mental retardation syndrome. Am J Hum Genet 79:549-55, 2006.

Nguyen DK, Disteche CM - High expression of the mammalian X chromosome in brain. Brain Res 1126:46-49, 2006.

Penrose LS - A clinical and genetic study 1280 cases of mental retardation defect. Special Report Series, Medical Research Council, $n^{\circ}$ 229. Her Majesty’s Stationary office, London, 1938. 
Plenge RM, Stevenson RA, Lubs HA, Schwartz CE, Willard HF - Skewed XChromosome inactivation is a commom feature of $\mathrm{X}$-linked mental retardation disorders. Am J Hum Genet 71:168-73, 2002.

Raymond FL, Whibley A, Stratton MR, Gecz J - Lessons learnt from large-scale exon re-sequencing of the X chromosome. Hum Mol Genet 18:60-64, 2009.

Ropers HH, Hamel BC - X-linked mental retardation. Nat Rev Genet 6:46-57, 2005.

Rosenberg C, Knijnenburg J, Bakker E, Vianna-Morgante AM, Sloos W, Otto PA, Kriek M, Hansson K, Krepischi-Santos AC, Fiegler H, Carter NP, Bijlsma EK, van Haeringen A, Szuhai K, Tanke HJ - Array-CGH detection of micro rearrangements in mentally retarded individuals: clinical significance of imbalances present both in affected children and normal parents. J Med Genet 43:180-6, 2006.

Scheffner M, Huibregtse JM, Vierstra RD, Howley PM - The HPV-16 E6 and E6-AP complex functions as a ubiquitin-protein ligase in the ubiquitination of p53. Cell 75:495-505, 1993.

Stocco dos Santos RC, Barretto OCO, Nonoyama K, Castro NHC, Ferraz OP, WalterMoura J, Vescio CCS, Becak W - X-linked syndrome: mental retardation, hip luxation, and G6PD variant (Gd(+) Butantan). Am J Med Genet 39:133-36, 1991.

Stocco dos Santos RC, Castro NH, Lillia Holmes A, Beçak W, Tackels-Horne D, Lindsey CJ, Lubs HA, Stevenson RE, Schwartz CE - Stocco dos Santos Xlinked mental retardation syndrome: clinical elucidation and localization to Xp11.3-Xq21.3. Am J Med Genet A 118:255-59, 2003.

Strom CM, Crossley B, Redman JB, Buller A, Quan F, Peng M, McGinnis M, Fenwick RG Jr, Sun W - Molecular testing for Fragile X Syndrome: lessons learned from 119,232 tests performed in a clinical laboratory. Genet Med 9:46-51, 2007. 
Tarpey PS, Smith R, Pleasance E, Whibley A, Edkins S, Hardy C, O'Meara S, Latimer C, Dicks E, Menzies A, Stephens P, Blow M, Greenman C, Xue Y, Tyler-Smith C, Thompson D, Gray K, Andrews J, Barthorpe S, Buck G, Cole J, Dunmore R, Jones D, Maddison M, Mironenko T, Turner R, Turrell K, Varian J, West S, Widaa S, Wray P, Teague J, Butler A, Jenkinson A, Jia M, Richardson D, Shepherd R, Wooster R, Tejada MI, Martinez F, Carvill G, Goliath R, de Brouwer AP, van Bokhoven H, Van Esch H, Chelly J, Raynaud M, Ropers HH, Abidi FE, Srivastava AK, Cox J, Luo Y, Mallya U, Moon J, Parnau J, Mohammed S, Tolmie JL, Shoubridge C, Corbett M, Gardner A, Haan E, Rujirabanjerd S, Shaw M, Vandeleur L, Fullston T, Easton DF, Boyle J, Partington M, Hackett A, Field M, Skinner C, Stevenson RE, Bobrow M, Turner G, Schwartz CE, Gecz J, Raymond FL, Futreal PA, Stratton MR - A systematic, large-scale resequencing screen of $\mathrm{X}$-chromosome coding exons in mental retardation. Nat Genet 41:535-43, 2009.

Toniolo D - In search of the MRX genes. Am J Med Genet 97:221-27, 2000.

Turner F, Gedeon A, Mulley J - X-linked mental retardation with heterozygous expression and macrocephaly: pericentromeric gene localization. Am J Med Genet 51:575-80, 1994.

Turner G, Partington MW - Genes for intelligence on the X chromosome. J Med Genet 28:429, 1991.

Van Esch H, Bauters M, Ignatius J, Jansen M, Raynaud M, Hollanders K, Lugtenberg D, Bienvenu T, Jensen LR, Gecz J, Moraine C, Marynen P, Fryns JP, Froyen G Duplication of the MECP2 region is a frequent cause of severe mental retardation and progressive neurological symptoms in males. Am J Hum Genet 77:442-53, 2005.

Vandewalle J, Van Esch H, Govaerts K, Verbeeck J, Zweir C, Madrigal I, Mila M, Pijkels E, Fernandez I, Kohlase J, Spaich C, Rauch A, Fryns JP, Marynen P, Froyen $\mathrm{G}$ - Dosage-dependent severity of the phenotype in patients with mental retardation due to a recurrent copy-number gain at Xq28 mediated by an unusual recombination. Am J Hum Genet 85:809-22, 2009.

Vicoso B, Charlesworth B - Evolution on the X chromosome: unusual patterns and processes. Nat Rev Genet 7:645-53, 2006. 
Wassarman DA, Sauer F - TAF(II)250: a transcription toolbox. J Cell Sci 114:2895902, 2001.

Weissman AM - Themes and variations on ubiquitylation. Nat Rev Mol Cell Biol 2:169-78, 2001.

Whibley AC, Plagnol V, Tarpey PS, Abidi F, Fullston T, Choma MK, Boucher CA, Shepherd L, Willatt L, Parkin G, Smith R, Futreal PA, Shaw M, Boyle J, Licata A, Skinner C, Stevenson RE, Turner G, Field M, Hackett A, Schwartz CE, Gecz J, Stratton MR, Raymond FL - Fine-scale survey of X chromosome copy number variants and indels underlying intellectual disability. Am J Hum Genet 87:173-88, 2010.

World Health Organization. The ICD-10 classification of neonatal and behavioral disorders - World Health Organization, Geneva, 1992.

Yoder M, Hildebrand JD - Shroom4 (Kiaa1202) is an actin-associated protein implicated in cytoskeletal organization. Cell Motil Cytoskeleton 64:49-63, 2007.

Zechner U, Wilda M, Kehrer-Sawatzki H, Vogel W, Fundele R, Hameister H - A high density of $\mathrm{X}$-linked genes for general cognitive ability; a run-away process shaping human evolution? Trends Genet 17: 697-701, 2001.

\section{Fontes da Internet:}

BLAST - Basic Local Alignment Search Tool - http://www.ncbi.nlm.nih.gov/BLAST/

Genatlas - http://http://www.genatlas.org/

GCC - Greenwod Genetic Center - http://www.ggc.org/xlmr.htm

NCBI - National Center for Biotechnology Information - http://www.ncbi.nih.gov/

PRIMER3 - http://frodo.wi.mit.edu/cgi-bin/primer3/

UCSC Genome Bioinformatics: http://genome.ucsc.edu.

Marshfield Center for Medical Genetics: http://research.marshfieldclinic.org/genetics/ Map_Markers/maps/IndexMapFrames.htm. 